ROCZNIKI TEOLOGICZNE

Tom LXVIII, zeszyt $4-2021$

DOI: https://doi.org/10.18290/rt21684-2

ALEKSANDER KRZYSZTOF SITNIK OFM

\title{
UDZIAŁ BERNARDYNÓW W POWSTANIU STYCZNIOWYM I ICH PÓŹNIEJSZE LOSY
}

\author{
BERNARDINE'S PARTICIPATION IN THE JANUARY UPRISING \\ AND THEIR SUBSEQUENT HISTORY
}

\begin{abstract}
A b stract. According to historians, the participation of the Order of Friars Minor (Bernardines) in the January Uprising was significant. In the light of historical sources Bernardine Fathers wrote a beautiful page in this national surge. As the historian of Bernardine Order Hieronim Eugeniusz Wyczawski claimed, it should be seen as a noble surge being the expression of love for the homeland and freedom. On the other hand it is impossible not to arrive at the conclusion that actions undertaken by Bernardine Fathers were frequently reckless and gullible or they lacked the ability to organize conspiratorial work. In the present elaboration I presented the activity of Bernardine Fathers in Congress Poland and on lands directly incarnated to Russian Empire which underwent big nationalistic oppression and where the bloody January Uprising broke out in $22^{\text {nd }}$ January 1863 in the Kingdom of Poland and in $1^{\text {st }}$ February 1863 in the former Grand Duchy of Lithuania. At the time multiple restrictions of monastic life occurred, also for Bernardine provinces. Not only did occupying authorities declare reluctance to such form of life, but they gradually limited and liquidated monastic structures, single monasteries and whole provinces. The dissolutions of the monasteries were accompanied with looting of their properties, taking away archives and libraries, exploiting of church and monastic premises for secular purposes. The dissolution broke Bernardine structures in the Kingdom of Poland. Many monks lost the sense of leading a monastic life what was manifested by frequent requests about secularization and emigration. It was the price that Bernardine Fathers paid for their patriotic engagement and binding their lives with the history of Polish society.
\end{abstract}

Keywords: Bernardine Fathers; monastery; dissolution.

Według historyków, udział Zakonu Braci Mniejszych (bernardynów) w powstaniu styczniowym był znaczący. Zapisali oni piękną kartę w tym zrywie narodowym. W niniejszym opracowaniu przedstawiona zostanie tylko ich

Dr hab. AleKSANDER KRZYSZTOF SitniK OFM - Wyższe Seminarium Duchowne O.O. Bernardynów w Kalwarii Zebrzydowskiej; adres do korespondencji: e-mail: krzysztofsitnik3@gmail.com 
działalność w Królestwie Kongresowym i na ziemiach bezpośrednio wcielonych do rosyjskiego imperium, gdzie był duży ucisk narodowościowy i gdzie wybuchło krwawe powstanie styczniowe: 22 stycznia 1863 r. w Królestwie Polskim i 1 lutego 1863 r. w byłym Wielkim Księstwie Litewskim. W czasie istnienia Królestwa Kongresowego wystąpiły wielorakie ograniczenia życia zakonnego, również dla prowincji bernardyńskich. Władze zaborcze nie tylko demonstrowały niechęć wobec tej formy życia, ale stopniowo ograniczały i likwidowały struktury zakonne, pojedyncze klasztory i całe prowincje. Kasatom klasztorów towarzyszyły grabieże ich mienia, zabór archiwów i bibliotek, a także wykorzystywanie pomieszczeń kościelnych i klasztornych na cele świeckie. Tematem tym zainteresował się bernardyński archiwista Kajetan Grudziński (1916-1986) ${ }^{1}$. Na jego pracy Bernardyni w stużbie ojczyzny 1453-1953 ${ }^{2}$ opierali się historycy zakonu, między innymi Hieronim Eugeniusz Wyczawski i Wiesław Franciszek Murawiec. Wiele cennych informacji do dziejów bernardynów w Królestwie Polskim wniósł również historyk, kapucyn, Roland Prejs ${ }^{3}$.

W 1864 r. bernardyni posiadali ogółem cztery prowincje (wielkopolską, małopolską litewską i ruską) z 56 klasztorami i 745 zakonnikami, w tym 467 kapłanami ${ }^{4}$. W Królestwie Polskim przed 1864 r. mieli dwie prowincje: małopolską i wielkopolską. Nazwy tych jednostek administracyjnych po rozbiorach nie miały już uzasadnienia geograficznego, a funkcjonowały jedynie siłą tradycji. Do pierwszej prowincji należały klasztory: w diecezji podlaskiej - w Jeleńcu, Krześlinie i Łukowie; w diecezji kieleckiej - w Karczówce koło Kielc; w diecezji sandomierskiej - w Kazanowie, Opatowie, Paradyżu, inaczej Wielkiej Woli i w Radomiu; w archidiecezji warszawskiej: w Kobyłce, inaczej Załuszynie; w diecezji lubelskiej - w Lublinie, Radecznicy oraz w Józefowie nad Wisłą. Jeden zakonnik przebywał jako kapelan sióstr

\footnotetext{
${ }^{1}$ Aleksander Krzysztof Sitnik, „Archiwista i muzealnik Kajetan Grudziński OFM (1916-1986)”, w: Niezwykli franciszkanie XX/XXI stulecia, cz. 2, red. Salezy Bogumił Tomczak (Poznań, 2012), 119-130.

${ }^{2}$ Praca znajduje się w Archiwum Prowincji oo. Bernardynów w Krakowie (dalej: APBK), sygn. RGP-k-111. Została poprawiona i opublikowana. Zob. Kajetan Jan Grudziński, Aleksander Krzysztof Sitnik, Bernardyni w stużbie Ojczyzny, 1453-1953 (Kalwaria Zebrzydowska, 2015).

${ }^{3}$ Roland Prejs, „Bernardyni w Królestwie Polskim po kasacie 1864 r.”, w: Pięćset pięćdziesiąt lat obecności oo. Bernardynów w Polsce (1453-2003), red. Wiesław Franciszek Murawiec, Damian Muskus (Kalwaria Zebrzydowska, 2006), 427-514.

${ }^{4}$ Piotr Paweł Gach, „Formy działalności Braci Mniejszych franciszkanów (bernardynów) na ziemiach dawnej Rzeczypospolitej w latach 1773-1914”, w: Pięćset pięćdziesiąt lat obecności oo. Bernardynów w Polsce (1453-2003), red. Wiesław Franciszek Murawiec, Damian Muskus (Kalwaria Zebrzydowska, 2006), 266.
} 
bernardynek w Świętej Katarzynie (diecezja sandomierska). Kościół klasztorny w Kobyłce był zarazem kościołem parafii administrowanej przez zakon.

Prowincję wielkopolską stanowiły klasztory: $w$ archidiecezji warszawskiej - w Czerniakowie koło Warszawy, Górze Kalwarii i Łęczycy, w diecezji kujawsko-kaliskiej - w Kaliszu, Kole, Piotrkowie Trybunalskim, Przyrowie, inaczej Świętej Annie, Warcie, Widawie i Złoczewie, w diecezji płockiej w Ostrołęce, Przasnyszu, Ratowie, Skępem i Strzegocinie, w diecezji sejneńskiej - w Tykocinie. Dwaj zakonnicy byli kapelanami sióstr bernardynek, jeden w Łowiczu (archidiecezja warszawska), drugi zaś w Wieluniu (diecezja kujawsko-kaliska). Bernardyni w Skępem we własnym kościele prowadzili duszpasterstwo parafialne, natomiast w Warszawie duszpasterzowali (choć bez prowadzenia formalnej parafii) w Grodzisku koło Warszawy. W obu prowincjach bernardyńskich w 1864 r. było łącznie 366 zakonników, w tym 231 kapłanów, 42 kleryków i 93 braci zakonnych ${ }^{5}$.

\section{KLASZTORY BERNARDYŃSKIE W CHWILI MANIFESTACJI RELIGIJNO-PATRIOTYCZNYCH}

Po upadku powstania listopadowego bernardyni w dalszym ciągu angażowali się na rzecz sprawy narodowej ${ }^{6}$. Widać to bardzo wyraźnie zwłaszcza w okresie organizowanych w Warszawie przez obóz czerwonych politycznych manifestacji. Działacze tego obozu, wykorzystując pogrzeb generałowej Katarzyny Sowińskiej, wdowy po legendarnym obrońcy miasta z 1831 r. Józefie Sowińskim, 11 czerwca 1860 r. zorganizowali pierwszą od powstania listopadowego demonstrację polityczną ${ }^{7}$. Tym samym rozpoczęli serię patriotycznych pochodów i manifestacji, świadomie nadając im charakter religijno-kościelny. Kościoły, jako miejsca licznych zgromadzeń, dawały stosunkowo duże poczucie bezpieczeństwa przed ingerencją policji carskiej. Z tego względu w kościele bernardynów (pw. św. Anny) i misjonarzy (pw. św. Krzyża) odprawiano przez

${ }^{5}$ Prejs, „Bernardyni w Królestwie Polskim po kasacie 1864 r.”, 428-429; tenże, Zakonnicy franciszkańscy Królestwa Polskiego po kasacie 1864 roku. Dzieje - postawy (Warszawa, 2003), 58, 61; Piotr Paweł Gach, Struktury i działalność duszpasterska zakonów męskich na ziemiach dawnej Rzeczypospolitej i Ślaska w latach 1773-1914 (Lublin, 1999), 103, 106, 107, 109.

${ }^{6}$ Zob. Aleksander Krzysztof Sitnik, „Udział Bernardynów w powstaniu listopadowym i popowstaniowe losy ich klasztorów”, Roczniki Teologiczne 67(2020), 4: 61-80.

${ }^{7}$ Hieronim Eugeniusz Wyczawski, Arcybiskup Zygmunt Szczęsny Feliński, 1822-1895 (Warszawa, 1975), 133-134; Jan Skarbek, „Sowińska ze Schroederów Katarzyna Antonina”, w: Polski stownik biograficzny, t. 40 (2000-2001), 632. 
cały tydzień nabożeństwa żałobne za poległych w powstaniu listopadowym. W 1860 r. w kościele św. Anny odprawiono mszę za trzech wieszczów i za powstańców, połączoną z patriotyczną manifestacją warszawskiej młodzieży gimnazjalnej. Na koniec nabożeństwa zgromadzeni odśpiewali Święty Boże..., Boże coś Polskę... i bez przeszkód rozeszli się do domów ${ }^{8}$. W okrągłą rocznicę ostatniego powstania, 29 listopada 1860 r., śpiewano i modlono się w intencji ojczyzny już na wszystkich ziemiach polskich.

Także w 1861 r. ludność Warszawy śpiewała w świątyniach pieśni religijne i patriotyczne. Władze zaborcze postanowiły stłumić te wystąpienia siłą. Kilka akcji zbrojnych dokonanych na bezbronnych manifestacjach miało bezpośredni związek z kościołem św. Anny. Do krwawych starć doszło 27 lutego 1861 r. podczas zajść na Placu Zamkowym i przed bernardyńskim klasztorem. Rosjanie zmusili manifestantów do opuszczenia placu przed kościołem św. Anny i szerokiej części Krakowskiego Przedmieścia, usuwając wszystkich siłą do wąskiego odcinka Krakowskiego Przedmieścia i w ulicę Senatorską. W tym czasie z kościoła bernardynów wyszedł kondukt pogrzebowy z zakonnikami śpiewającymi żałobne Miserere. Bernardyni na chwilę się wycofali, gdy żołnierze carscy zaatakowali kondukt, ale po chwili ponownie wyszli i nie ustępowali pomimo bicia nahajkami. W całym zamieszaniu odpadło jedno ramię krzyża procesyjnego, co zauważywszy, otaczający tłum zaczął wołać: „Zbóje, krzyże nam łamią, bezczeszczą świętości!” Na sotnie kozaków posypał się grad kamieni i lodu. Zakonnicy ponownie cofnęli się do kościoła. Po pewnym czasie kondukt wyruszył ponownie, ale już tylko z jednym księdzem i kilkoma osobami. Rosjanie próbowali rozłączyć manifestantów od konduktu, jednak nie byli w stanie opanować sytuacji. Kiedy komenderujący Rosjanami generał Wasyl Zabłocki dostał kamieniem w plecy, dał rozkaz strzelać do manifestantów. Od rosyjskich kul padło pięciu mężczyzn: czeladnik krawiecki Filip Adamkiewicz, uczeń gimnazjum realnego Michał Arcichiewicz, robotnik Karol Brendel oraz ziemianie Marceli Karczewski i Zdzisław Rutkowski. Zwłoki ofiar zostały przeniesione do Hotelu Europejskiego, który obległy tłumy. Przestraszony namiestnik Michaił Gorczakow wycofał wojsko do koszar, a na pogrzeb pięciu poległych udzielił zezwolenia. Odbył się on 2 marca $1861 \mathrm{r}$., gromadząc przedstawicieli wszystkich stanów i wyznań. Wzięli w nim udział między innymi rabini z Dow Ber Meiselsem na czele, a na trasie konduktu młodzież akademicka i szkolna

\footnotetext{
${ }^{8}$ Wiesław Franciszek Murawiec, „Zaangażowanie patriotyczne zakonników franciszkańskich Prowincji Niepokalanego Poczęcia NMP w Polsce”, w: Kościót w Polsce. Dzieje i kultura, t. 9, red. Jan Walkusz (Lublin, 2010), 306.
} 
utworzyła szpaler. Trudno dzisiaj ocenić, czy kondukt pogrzebowy celowo został przez zakonników wyprowadzony w momencie trwania manifestacji, co nie jest wykluczone, czy był to tylko zbieg okoliczności. Na celowy wybór pory wskazywałby fakt, że krzyż niósł nie bernardyn, lecz kapucyn br. Roger Zawistowski, a w kondukcie szli także inni kapucyni. Wynikałoby z tego, że zostali oni zaproszeni przez bernardynów specjalnie na tę okazję ${ }^{9}$.

Ta wyjątkowa atmosfera przetrwała do 8 kwietnia $1861 \mathrm{r}$., kiedy to odbył się w warszawskim kościele reformatów pogrzeb sybiraka Ksawerego Stobnickiego. Był on uczestnikiem spisku ks. Piotra Ściegiennego i spędził na katordze i zesłaniu kilkanaście lat. Schorowany powrócił do Warszawy, opromieniony sławą męczennika za sprawę narodową. Manifestująca w tym dniu ludność Warszawy wyruszyła z dwóch miejsc, a mianowicie z bernardyńskiego kościoła św. Anny i od kapucynów z ulicy Miodowej i skierowała się na Plac Zamkowy. Tym razem namiestnik Gorczakow posiadał carski rozkaz krwawego thumienia buntowniczych nastrojów. Na Placu Zamkowym Rosjanie zastosowali prowokację wymyśloną przez margrabiego Aleksandra Wielopolskiego. Przy dźwiękach werbli, skryty za oddziałami wojska, policjant trzykrotnie odczytał wezwanie do rozejścia się. Oczywiście, w ogólnym zamieszaniu poza Rosjanami nikt nie mógł go usłyszeć, rozpoczęła się zatem rzeź Polaków. Pomimo salw karabinowych uczestnicy nie rozproszyli się. Oddawali życie ze śpiewem pieśni religijnych. „Młody Żyd Michał Landy ujął w swoje ręce krzyż niesiony przez rannego zakonnika, ale cięty pałaszem zaraz też upadł"10. Rosyjski pisarz emigracyjny Aleksander Hercen tak opisał to wydarzenie: „Strzelano do bezbronnych obywateli jak do psów. Kobiety podniosły w górę dzieci, mężczyźni stali twardo przed wymierzonymi lufami, śpiewając Święty Boże, święty Mocny" ". Z rąk spojonych wódką żołdaków poległo ponad stu manifestantów.

Masakra na Placu Zamkowym dowiodła, że opór moralny nie przyniesie Polakom wolności. Mimo to nasilenie manifestacji patriotycznych nie ustało do jesieni $1861 \mathrm{r}$. Tylko w ciągu września i października tegoż roku w samej Warszawie urządzono ponad 200 demonstracji. Autorzy opracowań (m.in. W.F. Murawiec) wskazują, że najwięcej odbyło się ich w kościele reformatów i bernardynów oraz w katedrze. Kaznodzieje w kościele św. Anny wykorzystywali wszelkie nadarzające się okazje do głoszenia kazań patriotycznych.

\footnotetext{
${ }^{9}$ Prejs, „Zakonnicy franciszkańscy Królestwa Polskiego po kasacie 1864 roku”, 78; Wiesław Franciszek Murawiec, Bernardyni warszawscy. Dzieje klasztoru św. Anny w Warszawie 1454-1864 (Kraków, 1973), 175-177; Grudziński, Bernardyni w stużbie ojczyzny, 52-54.

${ }^{10}$ Stefan Kieniewicz, Powstanie styczniowe (Warszawa, 1972), 149.

${ }^{11}$ Aleksander Hercen, „Mater Dolorosa”, Kotokot 97 (1.05.1861).
} 
W stolicy bernardyni, w obawie przed represjami, ograniczali się do łatwo czytelnych przenośni i porównań, natomiast poza Warszawą wprost atakowali terror carski, nawiązując do krwawych zajść lutowych i kwietniowych w stolicy. Tego rodzaju wystąpienia karał sam dyrektor Komisji Rządowej Wyznań Religijnych i Oświecenia Publicznego w rządzie Królestwa Polskiego Aleksander Wielopolski, żądając karnego przeniesienia winnych zakonników do innego klasztoru ${ }^{12}$.

Po ogłoszeniu stanu wojennego przez nowego namiestnika Karola Lamberta i postawieniu przed sądem wojennym wielu uczestników pogrzebu arcybiskupa warszawskiego Antoniego Fijałkowskiego $(10 \mathrm{X} 1861)^{13}$, w rocznicę śmierci Tadeusza Kościuszki, 15 października 1861 r. odbyła się w Warszawie kolejna manifestacja. Swoim zasięgiem objęła wiele kościołów warszawskich, w których pod naciskiem wojska udało się rozproszyć manifestantów. Jedynie w trzech świątyniach na Starym Mieście: katedralnej, bernardynów i misjonarzy tłumy uczestników, uwięzione przez wojsko, pozostały cały dzień i noc z 15 na 16 października. Interweniowały u rządu $\mathrm{w}$ tej sprawie władze diecezjalne i zakonne. Biskup pomocniczy Jan Dekert nie został nawet wysłuchany, a gwardian warszawskich bernardynów Jan Połomski usłyszał od generała Stiepana Chrulewa: „Ciebie pierwszego powieszę! Oto masz odpowiedź tym, którzy cię posłali”"14. Na rozkaz generała Aleksandra Gerstenzweiga wojsko wtargnęło do kościoła św. Anny, by siłą opróżnić świątynię. Żołnierze zostali przez wiernych wyrzuceni z kościoła, ale za drugim razem, już uzbrojeni, spacyfikowali bezbronnych ludzi i aresztowali mężczyzn. Wypuszczono jedynie kobiety i dzieci. Z kolei po wejściu do kościoła misjonarzy Rosjan spotkało rozczarowanie, wierni bowiem poprzedniego dnia wieczorem wyszli podziemnym przejściem. Podczas tej akcji aresztowano w katedrze i u św. Anny półtora tysiąca mężczyzn. Odstawiono ich najpierw do zamku, a następnie do cytadeli ${ }^{15}$.

\footnotetext{
${ }^{12}$ Murawiec, „Zaangażowanie patriotyczne zakonników franciszkańskich”, 308; Henryk Eugeniusz Wyczawski, Bernardyni polscy, 1772-1946, t. 3 (Kalwaria Zebrzydowska, 1992), 162; Paweł Kubicki, Bojownicy kapłani za sprawę Kościoła i Ojczyzny w latach 1861-1915, cz. 3, t. 3 (Sandomierz, 1939), 280.

${ }^{13}$ Ryszard Bender, „Fijałkowski Antoni Melchior”, w: Encyklopedia Katolicka, t. 5, red. Piotr Hemperek (Lublin, 1989), 180.

${ }^{14}$ Mikołaj Wasiljewicz Berg, Pamiętniki o polskich spiskach i powstaniach (Kraków, 1880), 396.

${ }^{15}$ Prejs, Zakonnicy franciszkańscy Królestwa Polskiego po kasacie 1864 roku, 79; Wiesław Murawiec, „Warszawa - św. Anna”, w: Klasztory bernardyńskie $w$ Polsce $w$ jej granicach historycznych, red. Hieronim Eugeniusz Wyczawski (Kalwaria Zebrzydowska, 1985), 406-407; Stefan Kieniewicz, Warszawa w powstaniu styczniowym (Warszawa, 1954), 102; Berg, Pamiętniki o polskich spiskach i powstaniach, 396.
} 
Tragiczne zajścia w obu kościołach bernardyńskim i katedralnym były przedmiotem obrad warszawskiego konsystorza biskupiego 16 października 1861 r. pod przewodnictwem administratora archidiecezji, prałata Antoniego Białobrzeskiego. Pisemne sprawozdania w tej sprawie złożyli ks. Antoni Bernacki i bernardyn Kolumban Kolczyński, aresztowany 4 czerwca 1862 r. ${ }^{16}$ $\mathrm{Na}$ znak protestu proponowano zamknąć zbezczeszczone świątynie. Ostatecznie podjęto uchwałę, by zamknąć wszystkie kościoły i kaplice w Warszawie w celu zapobieżenia dalszym profanacjom. Zamknięcia kościoła bernardynów dokonał gwardian klasztoru Jan Mikołaj Połomski 16 października 1861 r. o godzinie osiemnastej ${ }^{17}$. Z duchowieństwem katolickim solidaryzowali się ewangelicy z pastorem Leopoldem Ottonem oraz rabini Ber Meisels, Izaak Kramsztyk i Markus Jastrow, zamykając warszawski kościół ewangelicki i synagogę ${ }^{18}$.

Upamiętnienie wypadków lutowych i kwietniowych miało miejsce w wielu klasztorach bernardyńskich. W Radomiu w maju 1861 r., pomimo zakazów władz zaborczych, w środy i soboty odbywały się nabożeństwa patriotyczne przed figurą Matki Bożej na zewnętrznym placu przykościelnym. Podobnie jak w innych miejscowościach na terenie Kongresówki, celem upamiętnienia lutowych i kwietniowych wydarzeń warszawskich, 8 sierpnia 1861 r. mieszkańcy miasta usypali kopiec na cmentarzu przy kościele bernardyńskim, wieńcząc go krzyżem oplecionym koroną cierniową. Wśród cierni umieszczono tabliczkę z napisem: „25, 27 lutego, 8 i 9 kwietnia 1861 r.” Do tego miejsca urządzano w latach 1861-1862 procesje religijno-patriotyczne wychodzące z bernardyńskiego kościoła klasztornego ze śpiewem zakazanych pieśni religijnych i patriotycznych: Boże, coś Polskę..., Serdeczna Matko..., $Z$ dymem pożarów... oraz ułożoną i śpiewaną jedynie u bernardynów w Radomiu Boże, lud Twój na kolanach... Po jednym ze spotkań kilkuset manifestantów zostało aresztowanych przez wojsko carskie. Ukarano również czterech bernardynów. Gwardiana klasztoru Telesfora Zaborka zamknięto w więzieniu za działalność patriotyczną 20 czerwca 1862 r., wkrótce jednak wrócił

${ }^{16}$ Wyczawski, Bernardyni, t. 3: 163; Murawiec, Bernardyni warszawscy, 180, 183; Archiwum Główne Akt Dawnych w Warszawie (dalej: AGAD) rkps Akta Stałej Komisji Śledczej, t. 1, poz. 4098.

${ }^{17}$ Prejs, „Zakonnicy franciszkańscy Królestwa Polskiego po kasacie 1864 roku”, 79; Kieniewicz, Warszawa w powstaniu styczniowym, 102.

${ }^{18}$ Wiesław Franciszek Murawiec, „Bernardyni warszawscy w powstaniu styczniowym 1863 roku", w: Historia vita memoriae. Prace dedykowane Księdzu Profesorowi Stanisławowi Ludwikowi Piechowi, red. Jan Bednarczyk (Kraków, 2009), 193-194; Prasa tajna z lat 1861-1864, cz. 1, red. Stefan Kieniewicz, I. Miller (Warszawa-Wrocław-Kraków, 1966), 28. 
do klasztoru. Kaznodzieję Justyna Melechowicza za kazanie patriotyczne wygłoszone 2 lutego 1862 r. aresztowano i zesłano w głąb Rosji, do guberni jenisejskiej. Podróż odbył pieszo razem ze zwykłymi zbrodniarzami. Kaznodziejów Jacka Lewczaka i Hilariona Koziorowskiego najpierw karnie przeniesiono do innego klasztoru, o. Lewczaka do Paradyża, zaś o. Koziorowskiego do Radecznicy. Następnie za organizowanie manifestacji w Radomiu skazano na zesłanie w głąb Rosji: o. Lewczaka do guberni saratowskiej, a o. Koziorowskiego aresztowano w Radecznicy i odbywał karę w twierdzy brzeskiej, a następnie został wysłany do Archangielska, gdzie przebywał do 1871 r. $^{19}$.

W Ratowie gwardian Antoni Holandyszkiewicz, w czasie dorocznego odpustu, urządził patriotyczną manifestację ze śpiewem zakazanych pieśni. W październiku, przed nabożeństwem za arcybiskupa Fijałkowskiego, Rosjanie wtargnęli do kościoła klasztornego, naruszając prawo azylu świątyni. Biskup diecezji płockiej nakazał na znak protestu zamknąć świątynię sprofanowaną przez wojsko carskie. W raportach rządowych wymieniono sześciu zakonników mieszkających w Ratowie jako najbardziej zaangażowanych w organizowanie manifestacji patriotycznych. Byli to: o. Piotr Kowalski, o. Augustyn Kozłowski, o. Apolinary Gawęcki, o. Franciszek Cichowski, o. Augustyn Soboliński oraz brat zakonny Roman Maltazar. Aresztowano tylko gwardiana Antoniego Holandyszkiewicza, zamykając go na dwa miesiące w twierdzy modlińskiej (7 listopada 1861-28 stycznia 1862) ${ }^{20}$.

Na kilkumiesięczny pobyt w zamojskiej fortecy i dłuższy nadzór policyjny byli skazywani bernardyni za nabożeństwa i procesje patriotyczne w Lublinie. Uroczystości takie organizował przeważnie o. Eustachy Szot. Wśród skazanych znaleźli się: gwardian Dydak Świeca za śpiewanie z ludem „niedozwolonych hymnów" w kościele w grudniu 1861 r. (miesiąc aresztu w twierdzy zamojskiej i nadzór policji), kaznodzieja Eustachy Goliński za kazanie patriotyczne wygłoszone 17 listopada $1861 \mathrm{r}$. (dwumiesięczny areszt w twierdzy zamojskiej), kaznodzieja Alfons Radomski, kaznodzieja January Kubaszka za kazanie wygłoszone w marcu 1862 r. (więzienie w twierdzy zamojskiej i przymusowy wyjazd do Galicji), a nawet kleryk Archanioł Gorczyca, który

${ }^{19}$ Michał Krawczyk, Wojciech Stan, Bernardyni radomscy. Zarys dziejów (Radom, 2013), 26; Murawiec, „Zaangażowanie patriotyczne zakonników franciszkańskich”, 310; Kajetan Grudziński, „Radom”, w: Klasztory bernardyńskie w Polsce, 297; Augustyn Chadam, „Radecznica”, w: Klasztory bernardyńskie w Polsce, 287; Grudziński, Bernardyni w stużbie ojczyzny, 69-78; APBK rkps I-1-12, Wykaz alfabetyczny Biskupów i Kapłanów oraz Zakonników polskich przebywających do obecnej chwili na wygnaniu w Syberii i głębokiej Rosji (1881), 7.

${ }^{20}$ Wyczawski, Bernardyni, t. 3: 167, 168; Murawiec, Bernardyni warszawscy, 180. 
w czasie kazania patriotycznego o. Golińskiego usunął z kościoła klasztornego funkcjonariusza policji i nazwał go szpiegiem. Autor raportu do generała-policmajstra o klasztorze lubelskim bernardynów stwierdził, że „nie było żadnej manifestacji, która by nie wychodziła z klasztoru bernardynów, a na jego murach najpierw pojawiały się wszelkiego rodzaju plakaty rewolucyjne i dyrektywy organizatorów powstania" ${ }^{21}$.

Do bernardyńskiego sanktuarium maryjnego w Skępem przybywali pielgrzymi również w rocznice wydarzeń warszawskich. Śpiewali wówczas pieśni religijne i patriotyczne. Kazania patriotyczne głosił do nich o. Bonifacy Jastrzębski (zm. 1894). Po kazaniu w czasie mszy żałobnej w rocznicę śmierci polskiego historyka Joachima Lelewela o. Jastrzębski został aresztowany. W drodze do więzienia udało mu się uciec z konwoju. Wyemigrował do Francji. W 1879 r. wrócił przez Bawarię i Saksonię na teren Galicji i w Krakowie pełnił obowiązki kapelana bernardynek przy ulicy Poselskiej ${ }^{22}$.

Stosunkowo najłagodniej władze zaborcze potraktowały manifestantów w Piotrkowie Trybunalskim. 8 kwietnia 1862 r. odbyła się manifestacja przy krzyżu postawionym 27 lutego 1862 r. na cmentarzu przykościelnym bernardynów z dużym napisem: „Na pamiątkę ofiar pomordowanych w Warszawie w 1861 r.” Po śledztwie w sprawie zajść piotrkowskich żołnierze carscy usunęli napis z krzyża. Aresztowano również wikarego klasztoru bernardynów Cyryla Malinowskiego, ale wkrótce go zwolniono ${ }^{23}$.

W kościele bernardynów w Tykocinie 2 sierpnia 1861 r. odbyła się manifestacja z okazji odpustu Matki Bożej Anielskiej. Patriotyczne kazanie wygłosił zakonnik z innego klasztoru bernardyńskiego. Wierni śpiewali pieśni patriotyczne i religijne ${ }^{24}$.

${ }^{21}$ Prejs, „Zakonnicy franciszkańscy Królestwa Polskiego po kasacie 1864 roku”, 81-80; Augustyn Chadam, „Lublin”, w: Klasztory bernardyńskie w Polsce, 192; Murawiec, Bernardyni warszawscy, 181; Grudziński, Bernardyni w stużbie ojczyzny, 65-66.

${ }^{22}$ Aleksander Krzysztof Sitnik, „Różnorodne formy kultu Matki Bożej Skępskiej”, w: Rozwój kultu Matki Bożej inspirowany przez figurę Najświętszej Maryi Panny Skęskiej Królowej Mazowsza, Kujaw i Ziemi Dobrzyńskiej, red. Aleksander Krzysztof Sitnik (Kalwaria Zebrzydowska, 2018), 15; Romuald Gustaw, Klasztor i kościót św. Józefa ss. bernardynek w Krakowie, 1646-1946 (Kraków, 1947), 101 (zob. Romuald Michał Gustaw, Aleksander Krzysztof Sitnik, Klasztor i kościót św. Józefa ss. Bernardynek w Krakowie, 1646-2009 [Kalwaria Zebrzydowska, 2013]); Grudziński, Bernardyni w stużbie ojczyzny, 65; APBK rkps XIII-10a, Kronika klasztoru oo. Bernardynów w Skępem (1933-1978), 3.

${ }^{23}$ Wyczawski, Bernardyni, t. 3: 166; Kajetan Grudziński, „Piotrków Trybunalski”, w: Klasztory bernardyńskie w Polsce, 262.

${ }^{24}$ Małgorzata Choińska, „Tykocin w czasie powstania styczniowego”, Studia Podlaskie (2006), 16: 12. 
Według relacji urzędowej, w klasztorze w Widawie bernardyni odprawiali nabożeństwa za poległych, śpiewali pieśni patriotyczne, wygłaszali „podburzające” kazania. Oskarżenie za tego rodzaju „przestępstwa” spadło na gwardiana klasztoru Marcelego Wójcika i o. Damiana Śliwińskiego ${ }^{25}$.

W kościele klasztornym w Łukowie gwardian Cherubin Lisiewicz i o. Arseniusz Kawczyński urządzili nabożeństwo za pięciu poległych, połączone z poświęceniem i ustawieniem pamiątkowego krzyża ${ }^{26}$.

Prawdopodobnie w wielu innych kościołach bernardyńskich odbywały się manifestacje, a przynajmniej zakonnicy głosili patriotyczne kazania. Raporty policyjne z lutego i kwietnia 1861 r. przedstawiały bernardynów i kapucynów jako podżegaczy i przywódców ludu. $Z$ tego względu Aleksander Wielopolski wezwał prowincjała bernardynów Michała Łukomskiego i skarcił go, że nie potrafi utrzymać swych zakonników w rygorze i pozwala im na działalność antyrządową. Łukomski, wystraszony groźbą rozwiązania prowincji, wezwał wówczas bernardynów osobną kurendą 6 maja 1863 r. do modlitwy i nakazał odprawiać co miesiąc we wszystkich kościołach klasztornych msze i litanie o zachowanie prowincji, nie uchroniło go to jednak od podejrzeń o sprzyjanie powstaniu. Na kategoryczne polecenie Wielopolskiego zrezygnował z urzędu prowincjała 17 lipca 1863 r. $^{27}$

Taka reakcja duchowieństwa poważnie zaskoczyła namiestnika Karola Lamberta, który nie życzył sobie zbyt wielkiego rozgłosu warszawskich zajść w Europie. Zażądał od kapituły wytłumaczenia się, a po pisemnej odpowiedzi, mającej charakter oskarżenia pod adresem rządu, nakazał aresztować administratora Antoniego Białobrzeskiego i członków kapituły. Sam jednak, po ostrej sprzeczce ze swym zastępcą generałem Gerstenzweigiem w sprawie zwolnionych oraz po samobójstwie tego ostatniego, ciężko się rozchorował, złożył urząd i opuścił Warszawę. Mówiono wtedy, że winowajców dotknęła zasłużona kara.

Zamknięcie kościołów położyło wprawdzie kres manifestacjom patriotycznym, ale ostry kurs następnego namiestnika Aleksandra Lüdersa przyczynił się do rozszerzenia siatki spiskowej na prowincję i przyśpieszył przygotowania do powstania zbrojnego. Rozgłos w Europie, wywołany zamknięciem warszawskich kościołów nie tylko katolickich, ale również protestanckich

\footnotetext{
${ }^{25}$ Grudziński, Bernardyni w stużbie ojczyzny, 67.

${ }^{26}$ Prejs, „Zakonnicy franciszkańscy Królestwa Polskiego po kasacie 1864 r.”, 80.

${ }^{27}$ Barbara Kalinowska, „Kasata zakonów w Królestwie Polskim jako konsekwencja ich zaangażowania w powstanie styczniowe", Zeszyty Naukowe Ostrołęckiego Towarzystwa Naukowego (2003), 17: 40-41; Kamil Kantak, Bernardyni polscy, 1573-1795-1932, t. 2 (Lwów, 1933), 545.
} 
i żydowskiej synagogi, jak również wydalenie z kraju rabina Meiselsa, nie był na rękę caratowi. Chcąc doprowadzić do załagodzenia kłopotliwej sytuacji, Petersburg odwołał się do pośrednictwa papieża Piusa IX, który zajmował dotychczas postawę wyczekującą wobec Rosji, łudząc się nadzieją ustanowienia nuncjatury $\mathrm{w}$ Petersburgu ${ }^{28}$. Obie strony były przekonane, że trudną sytuację w Warszawie można rozwiązać tylko przez obsadzenie wakującego tam urzędu arcybiskupa. Carski rząd poszedł $\mathrm{w}$ tym wypadku papieżowi na rękę, wysuwając kandydaturę ks. Szczęsnego Felińskiego (1822-1895). Nowy arcybiskup zajął stanowisko ugodowej polityki i jako pierwszy cel swoich rządów postawił normalizację stosunków kościelno-państwowych. W związku z tym zarządził rekoncyliację sprofanowanych kościołów i otwarcie wszystkich innych kościołów i kaplic w Warszawie z równoczesnym nakazem odprawienia czterdziestogodzinnego nabożeństwa. Już 13 lutego 1862 r. sufragan łowicki biskup Henryk Plater rekoncyliował kościół bernardynów, sam zaś arcybiskup odprawił podobne nabożeństwo w katedrze, gdzie wygłosił kazanie, nawołując do modlitw za ojczyznę i do zaprzestania śpiewów politycznych w kościołach. Ludność Warszawy, będąca jeszcze pod wrażeniem wypadków 1861 r., uznała jego linię polityczną za nadmierną uległość wobec caratu i opuściła katedrę, wkrótce jednak miała się przekonać o słuszności jego postępowania. Przedwcześnie wywołane powstanie styczniowe (po brance ogłoszonej 6 października 1862 r. z inicjatywy Aleksandra Wielopolskiego) oraz brak oparcia konspiracyjnych organizacji miejskich w najliczniejszej warstwie społecznej, jaką stanowili chłopi, ściągnęło na kraj nową i groźniejszą w skutkach tragedię, powstanie bowiem wkrótce upadło i nastały niekończące się represje wraz z utratą wszelkiej samodzielności Królestwa. Sam arcybiskup Feliński stał się jego mimowolną ofiarą, gdyż protestując przeciw represjom caratu, został już w czerwcu 1863 r. skazany na zesłanie do Jarosławia nad Wołgą ${ }^{29}$.

\section{UDZIAŁ BERNARDYNÓW W POWSTANIU STYCZNIOWYM I ICH PÓŹNIEJSZE LOSY}

W trudnym okresie lat 1863-1864 naturalnymi sprzymierzeńcami powstańców były klasztory, które dotychczas tak gorliwie patronowały patriotycznym

\footnotetext{
${ }^{28}$ Zygmunt Zieliński, Papiestwo i papieże dwóch ostatnich wieków (Warszawa, 1999), 199.

${ }^{29}$ Wyczawski, Arcybiskup Zygmunt Szczęsny Feliński, 285; Murawiec, Bernardyni warszawscy, 181-182.
} 
manifestacjom. Wielu zakonników wzięło udział w powstaniu z przekonania, a liczne klasztory i plebanie były ważnymi punktami werbunkowymi, którym patronowali księża. Jeśli chodzi o klasztory bernardynów, to na czoło wysunął się konwent św. Anny w Warszawie. 22 lutego 1863 r. został aresztowany i osadzony w cytadeli kaznodzieja zwyczajny Honoriusz Jarnuszkiewicz. Stała Komisja Śledcza określiła go w oskarżeniu jako „aktywnego buntownika i płomiennego mówcę". Dopiero po interwencji 6 marca arcybiskupa Zygmunta Felińskiego u dyrektora głównego Komisji Rządowej Wyznań Religijnych i Oświecenia Publicznego zwolniono go $\mathrm{z}$ więzienia po dwóch miesiącach (21 kwietnia), zmieniając tylko w akcie oskarżenia sformułowanie „buntownicze przemówienia” na „dwuznaczne wyrażanie się w kazaniach”30. W czasie przygotowań do powstania styczniowego przebywał w Warszawie i werbował ochotników, wykorzystując do tego celu nawet spowiedź, bernardyn Filip Markowski. Podczas śledztwa niejaki Wincenty Sosnowski, zwerbowany przez niego powstaniec zeznał (23 lipca), że poszukiwany przez Rosjan bernardyn namówił go do złożenia przysięgi powstańczej. W tym czasie o. Markowski wyjechał poza Warszawę i przebywał w powiecie opoczyńskim w charakterze kapelana oddziału Dzieci Warszawy, zorganizowanego przez majora Ludwika Żychlińskiego. Po klęsce oddziału 6 września dostał się do niewoli. Wyrokiem Audytoriatu Polowego został skazany na piętnaście lat katorgi w nieznanej syberyjskiej kopalni. Według relacji Tymczasowej Komisji Śledczej, po zatwierdzeniu wyroku przez namiestnika (18 września) udało mu się uciec $\mathrm{z}$ aresztu i wyjechać z kraju, jednak Edward Nowakowski zamieszcza jego nazwisko w 1874 r. wśród zesłańców w Tunce na Syberii, a autor spisu zesłańców z lat 1876-1881 wymienia go pod $1877 \mathrm{r}$. jako zesłańca w Nowomoskowsku w guberni jekaterynosławskiej ${ }^{31}$.

21 września 1863 r. władze carskie ostatecznie ujawniły działalność powstańczą zakonników z klasztoru św. Anny w Warszawie. W czasie szczegółowej rewizji klasztoru aresztowano przebywających tam pięciu świeżo zwerbowanych powstańców. Po dwu następnych rewizjach znaleziono ukrytą w ogrodzie maszynę drukarską, prawie 200 kompletów umundurowania, 24 formy do odlewania kul, 24 ostrza na piki, siedem funtów ołowiu, około 100 sztyletów i ponad 20 elementów konnej uprzęży ${ }^{32}$. Dekonspiracja ośrodka

\footnotetext{
${ }^{30}$ Wyczawski, Bernardyni, t. 3: 163; Murawiec, „Zaangażowanie patriotyczne zakonników franciszkańskich", 312; tenże, Bernardyni warszawscy, 183.

${ }^{31}$ Murawiec, Bernardyni warszawscy, 183, 184; Edward Nowakowski, „Spis duchowieństwa przebywającego w Tunce na Syberii”, w: W czterdziesta rocznice powstania styczniowego (Lwów, 1903), 480; APBK rkps I-ł-12, Wykaz alfabetyczny, 8.

${ }^{32}$ Murawiec, „Zaangażowanie patriotyczne zakonników franciszkańskich”, 313.
} 
powstańczego pociągnęła za sobą aresztowanie w październiku trzech najbardziej podejrzanych o działalność powstańczą bernardynów: lektora historii Kościoła Mariana Misińskiego, wikarego klasztoru Konstantyna Goździewskiego (Gozdowskiego), najbardziej aktywnego działacza powstańczego Gwidona Komorowskiego oraz nowo wybranego prowincjała Zefiryna Zarębskiego (Zarębę) ${ }^{33}$. Pod zarzutem ukrywania powstańców bądź kontaktowania się z nimi Tymczasowa Komisja Śledcza skazała ich na zesłanie w głąb Rosji ${ }^{34}$. Zanim wyrok został uprawomocniony, Rosjanie, chcąc zapewne wykryć całą siatkę spiskową w klasztorze św. Anny, po kilku miesiącach pobytu w cytadeli i półrocznym więzieniu w twierdzy modlińskiej uwolniły Goździewskiego na podstawie wyjaśnienia, że był on zakonnikiem klasztoru w Przyrowie i dopiero od niedawna przebywał w Warszawie ${ }^{35}$. Wszystkich innych zakonników klasztoru św. Anny w Warszawie, w trakcie kasaty klasztoru, przewieziono nocą z 15 na 16 listopada pod dowództwem porucznika Kosińskiego do obozu dla zakonników w Kole nad Wartą ${ }^{36}$. Z 31 bernardynów warszawskich przewieziono wówczas 22 osoby, gdyż zgodnie z ukazem, pozostawiono przy kościele do posługi duszpasterskiej jednego bernardyna Dionizego Czaczkowskiego, a dwóch innych: brata zakonnego Zozyma Popiela i o. Stefana Cieślińskiego aresztowano w czasie zamknięcia klasztoru wskutek denuncjacji o ich udziale w powstaniu. Lojalny wobec rządu administrator archidiecezji warszawskiej Stanisław Zwoliński z początkiem $1866 \mathrm{r}$. przeniósł seminarium duchowne $\mathrm{z}$ ulicy Jezuickiej nr 4 do klasztoru pobernardyńskiego św. Anny, gdzie istniało ono do października roku następnego. W 1867 r. większą część budynku poklasztornego przejęły władze miejskie, a część przylegającą do kościoła i sam kościół św. Anny wzięły pod jurysdykcję władze archidiecezji ${ }^{37}$.

Władze carskie nakładały na klasztory sympatyzujące z powstaniem wysokie kontrybucje. Klasztor bernardynów w Czerniakowie na skutek raportu Komisji Rządowej Wyznań Religijnych i Oświecenia Publicznego z 27 czerwca 1864 r. otrzymał grzywnę w wysokości 3000 rubli. Kiedy bernardyni zwrócili się do namiestnika Królestwa Polskiego hrabiego Berga o zmniejszenie sumy

${ }^{33}$ Kalinowska, „Kasata zakonów w Królestwie Polskim”, 41; Wyczawski, Bernardyni, t. 3: 163, 164; tenże, „Strzegocin”, w: Klasztory bernardyńskie w Polsce, 359; AGAD, fasc. Dieło po monastyrskoj reformie, cz. 1, VII-VIII, 1864, w zespole: Zarząd Generał-policmajstra, nr 14, k. $25 \mathrm{v}, 66,81 \mathrm{v}$.

${ }^{34}$ Kantak, Bernardyni, t. 2: 545.

${ }^{35}$ Kubicki, Bojownicy kaptani, cz. 1, t. 3: 618

${ }^{36}$ AGAD, fasc. Dieło po monastyrskoj reformie, cz. 2, w zespole: Zarząd Generał-policmajstra, nr 15, k. 144

${ }^{37}$ Wyczawski, Bernardyni, t. 3: s. 163; Murawiec, Bernardyni warszawscy, 190, 191. 
kontrybucyjnej, namiestnik prośbę odrzucił, ponieważ klasztor sprzyjał powstańcom, czego dowodem było udzielenie schronienia klerykowi swego zakonu Bartłomiejowi Rybusowi, który brał czynny udział w powstaniu i niedawno wrócił do klasztoru. Berg zgodził się jedynie na spłacenie grzywny w kwartalnych ratach. Gwardian Grzegorz Gutowski, w związku ze sprawą kleryka Bartłomieja Rybusa, został aresztowany i skazany na osiedlenie w północno-wschodniej części carskiego imperium. Kasata klasztoru czerniakowskiego nastąpiła w nocy z 27 na 28 listopada 1864 r. Znajdowali się tam wtedy ojcowie: gwardian Grzegorz Gutowski, wikary Bernard Przetakiewicz, Justyn Walkowski, Henryk Betlejemski oraz bracia zakonni Leon Gardowski, Alojzy Baczyński, Marek Parskiewicz, Wenanty Siedlecki. Przewieziono ich razem z bernardynami z warszawskiego klasztoru św. Anny do bernardyńskiego klasztoru etatowego w Kole nad Wartą. Pod koniec $1864 \mathrm{r}$. klasztor czerniakowski został obsadzony przez wojsko rosyjskie. Zwożono tutaj zakonników ze skasowanych klasztorów, którzy wyrazili chęć wyjazdu za granicę. Było ich razem trzydziestu jeden. Przez okres dwóch miesięcy trzymano ich pod nielitościwym nadzorem pułkownika Holsteina, następnie odstawiono do granicy. W skasowanym klasztorze carskie władze pozostawiły na pewien czas bernardyna Justyna Walkowskiego do obsługi kościoła, który przebywał tutaj do 1869 r., kiedy rektorem świątyni został z ramienia kurii metropolitalnej ksiądz diecezjalny, a Walkowski pojechał do Koła. Po wywiezieniu bernardynów całe mienie klasztorne stało się własnością państwa. 17 (8) lutego 1865 r. namiestnik Królestwa Polskiego polecił oddanie bibliotek poklasztornych seminariom diecezjalnym. W piśmie do biskupów motywował swoją decyzję brakiem należytego dozoru i innym przeznaczeniem gmachów poklasztornych, w których zbiory mogłyby zostać uszkodzone. Biblioteka klasztorna jako „nieprzydatna dla bibliotek publicznych” została w całości przekazana do seminarium duchownego w Warszawie, podobnie jak wszystkie cenniejsze obrazy. Księgozbiór w chwili kasaty liczył około 1000 woluminów. Budynek klasztorny po kasacie uległ wewnątrz pewnym przeróbkom, jedynie tylko dolny korytarz, przylegający do kościoła, zachował swoją dawną barokową architekturę. Zniesiono małe cele, usuwając dzielące je ściany, a stworzono obszerne pokoje. Korytarze na piętrze przestały istnieć, bo wykorzystano je na różne składy i komórki. Skrzydło przylegające do świątyni zajmowali rektorzy kościoła, drugie wzdłuż ul. Czerniakowskiej przeszło pod zarząd tzw. Mariańskiego Prijuta (Przytułku Najświętszej Maryi Panny), przeznaczonego dla sierot po żołnierzach polskich odbywających służbę wojskową w armii rosyjskiej. Ta część klasztoru została odrestaurowana i odpowiednio zaadaptowana do swego obecnego przezna- 
czenia. Nieco później budynek został oddany na własność gromadzie Czerniaków, która opróżnioną przez Prijut część klasztoru wydzierżawiła szarytkom. Istniejąca przed kasatą czteroklasowa szkoła elementarna w budynku gospodarczym przeniosła się po kasacie do dawnego refektarza. Nosiła odtąd nazwę Naczelnoje uczyliszcze, w którym nauczano w języku rosyjskim ${ }^{38}$.

Klasztor bernardyński w Górze Kalwarii koło Warszawy stał się ośrodkiem aprowizacyjnym powstania. Za tę działalność byli karani gwardian Józef Ludwinowski (vel Józefat Ludwiński) i Bazyli Tyrek, który został skazany na katorgę $\mathrm{w}$ guberni kostromskiej, jednakże wśród ogólnej kasaty klasztorów w 1864 r. oszczędzono go. Uległ zniesieniu dopiero w 1873 r. Liczył wówczas jedenastu zakonników ${ }^{39}$.

Powstanie styczniowe zadecydowało również o dalszym losie klasztoru bernardynów w Józefowie nad Wisłą. Władze carskie uznały za nieprawomyślnych gwardiana Waleriana Barańskiego (vel Baranowskiego) i o. Filipa Banasińskiego. Za podejrzanego politycznie uznano również kaznodzieję Symforiana Górzewskiego. Klasztor nie został skasowany w pierwszej fazie, tzn. pod koniec 1864 r., jak większość klasztorów bernardyńskich, lecz nieco później, bo 2 października 1865 r. Zakonników wywieziono do etatowego klasztoru bernardynów w Paradyżu. Kościół klasztorny stał się filią świątyni parafialnej. Bibliotekę przeznaczono dla seminarium duchownego w Lublinie. W kilkuletnim oczekiwaniu na transport, została niemal w połowie rozgrabiona. Proboszcz z Rybitw przesłał ją do Lublina „po usunięciu z niej bezwartościowych papierów" ${ }^{40}$. Tymi bezwartościowymi papierami - w ocenie prostego plebana - było cenne archiwum klasztoru. W 1959 r. bernardyni przypadkiem odzyskali prawdopodobnie jedyny zachowany rękopis, znajdujący się obecnie w Archiwum Prowincji oo. Bernardynów w Krakowie pod sygnaturą S-jó-1, Chronica conventus Josephoviensis ordinis Minorum S.P.N. Francisci Regularis Observantiae [- -] Provinciae Russiae [- -] desolationem et ruinam propter fortuitum ignem primi conventus [- -] et ecclesiae novam fundationem conventus ac ecclesiae ex muro et latere [- -] ab [- -] Josepho a Potok Potocki [- -] palatino Kijoviensi supremo duce exercituum Regni Polo-

\footnotetext{
${ }^{38}$ Gach, „Formy działalności Braci Mniejszych”, 302; Wyczawski, Bernardyni, t. 3: 164; Kajetan Grudziński, „Warszawa-Czerniaków”, w: Klasztory bernardyńskie w Polsce, 413; Murawiec, Bernardyni warszawscy, 185.

${ }^{39}$ Prejs, „Zakonnicy franciszkańscy Królestwa Polskiego po kasacie 1864 r.”, 86; Wyczawski, Bernardyni, t. 3: 164-165; Wiesław Murawiec, „Góra Kalwaria”, w: Klasztory bernardyńskie w Polsce, 74; Kajetan Grudziński, „Działalność patriotyczna”, w: Zakon Braci Mniejszych franciszkanów, cz. 3. Zakony św. Franciszka w Polsce w latach 1772-1970, red. Joachim Roman Bar (Warszawa, 1978), 115.

40 Taką między innymi uwagę zapisał w protokole.
} 
niae fundatare consecrationem ejusdem ecclesiae, erectionem nec non alia digna scitu breviter in se complectens de nova radice cura et industria M.V. Patris Ludovici Czuryto guardiani [- -] ejusdem conventus [- -] efformata a. D. 1744, obejmujący wydarzenia od 9 grudnia 1692 r. do 15 stycznia 1859 r. ${ }^{41}$

Kaliski klasztor bernardynów był ważnym punktem zbiorczym powstańców. Bernardyni odbierali w kościele klasztornym przysięgi powstańcze. Kapelan oddziału Mariana Langiewicza, Feliks Dąbrowski, był przez pewien czas naczelnikiem okręgu kaliskiego. Po upadku powstania i internowaniu przez władze austriackie udał się na emigrację do Stanów Zjednoczonych. W klasztorze został aresztowany kleryk Anzelm Czapliński za przechowywanie i propagowanie wierszy powstańczych. O powstańczą działalność zostali oskarżeni kaznodzieja Zygmunt Malinowski i brat zakonny Wawrzyniec Jarosz, zesłany do guberni archangielskiej. W klasztorze krótko przebywał kleryk Bartłomiej Rybus. W 1863 r. nałożono na klasztor kontrybucję w wysokości 600 rubli. W celu realizacji postanowienia namiestnika Królestwa Polskiego naczelnik powiatu kaliskiego 13(25) czerwca 1864 r. polecił zająć wszelkie fundusze klasztoru bernardynów w Kaliszu. W Kaliszu w momencie kasaty w grudniu 1864 r. mieszkało w konwencie siedemnastu zakonników. Byli to: gwardian klasztoru Tadeusz Błeszczyński, były gwardian i definitor prowincji Antoni Majewski, lektor filozofii Aleksy Gołębiowski, kaznodzieja Błażej Gorbieński, magister kleryków Marian Sidorowicz, Makary Lewachowicz, Ignacy Ignaczewski, Feliks Dąbrowski, Kasjan Piessa, klerycy profesi: Atanazy Karwowski, Adolf Aranowski, Wincenty Rydlewski, Apoloniusz Kukowski, Ignacy Rumiński, Apolinary Maday i bracia laiccy: Wenanty Siedlecki i Serafin Alachamowicz. Wymienieni ojcowie i bracia przewiezieni zostali do klasztorów w Kazimierzu Biskupim i Kole. O Rafale Podgórskim wiadomo, że udał się na emigrację do Belgii, potem do Włoch i tam zmarł w Asyżu w 1893 r. W trakcie likwidacji konwentu zniszczono archiwum konwentu i kościoła, skradziono cenne wyposażenie kościelne. Książki z biblioteki klasztornej zawędrowały do bibliotek: miejskiej w Bydgoszczy, seminariów duchownych we Włocławku i Sandomierzu oraz do archiwum archidiecezjalnego w Poznaniu. Po usunięciu zakonników obiekt klasztorny przekazano rosyjskiemu kaliskiemu towarzystwu dobroczynności ${ }^{42}$.

${ }^{41}$ Wyczawski, Bernardyni, t. 3: 186; tenże, „Katalog Archiwum Prowincji oo. Bernardynów w Krakowie”, ABMK (1962), 4: 156; Grudziński, „Józefów”, w: Klasztory bernardyńskie w Polsce, 102.

${ }^{42}$ Sławomir Przygodzki, „Losy bernardynów kaliskich i klasztoru w okresie zaborów (17931914)”, w: 400 lat konsekracji pobernardyńskiego kościoła jezuitów w Kaliszu. Materiały z sesji popularnonaukowej poświęconej historii światyni i przylegającego do niej klasztoru, red. Jerzy 
Liczny udział w powstaniu styczniowym wzięli bernardyni z klasztoru w Kazimierzu Biskupim. Należeli do nich: gwardian January Walkowski, kaznodzieja Wincenty Usarski (vel Uzarski), lektor Zefiryn Strupczewski, Stefan Cieśliński, Atanazy Karwowski, Rafał Stasinkowski oraz klerycy: Augustyn Rymarkiewicz, Michał Wieczorkiewicz, Maciej Morawski. W potyczce 24 marca 1863 r. polegli Stasinkowski oraz klerycy Rymarkiewicz, Wieczorkiewicz i Morawski, reszta zginęła 5 czerwca 1863 r. Ocalało jedynie dwóch bernardynów: gwardian Walkowski i kaznodzieja Usarski, przeciw którym prowadzono śledztwo. Mimo kasaty klasztorów konwent kazimierski oszczędzono. Istniał do 1898 r., kiedy to został zniesiony, a zakonników przewieziono do Koła nad Wartą ${ }^{43}$.

Klasztor w Kielcach na Karczówce odegrał znaczną rolę w powstaniu styczniowym. Służył powstańcom jako punkt zborny przed uderzeniem na rosyjski garnizon, stacjonujący w Kielcach w nocy z 10/11 stycznia 1863 roku $^{44}$. Bernardyn z Karczówki Antoni Majewski zgłosił się na kapelana wojsk generała Mariana Langiewicza. Zginął podczas bitwy pod Grochowiskami w pobliżu wsi Szaniec 19 marca 1863 r., gdy udzielał rannym powstańcom ostatnich sakramentów. Został pochowany na cmentarzu w Busku ${ }^{45}$.

Kacprzyk, Aleksander Jacyniak (Kalisz, 2007), 69, 70, 71; Wyczawski, Bernardyni, t. 3: 165; Wiesław Franciszek Murawiec, „Kalisz”, w: Klasztory bernardyńskie w Polsce, 112; tenże, Bernardyni warszawscy, 185.

${ }^{43}$ Piotr Gołdyn, Franciszkanie w powstaniu styczniowym na ziemi konińskiej (Konin, 2002), 39-40, 48, 55-56; Wyczawski, Bernardyni, t. 3: 163, 165; tenże, „Kazimierz Biskupi”, w: Klasztory bernardyńskie w Polsce, 132; Grudziński, Bernardyni w służbie ojczyzny, 111.

${ }^{44}$ Wiesław Franciszek Murawiec, „Kielce”, w: Klasztory bernardyńskie w Polsce, 134; Kantak, Bernardyni, t. 2: 544.

${ }^{45}$ Ewa Jabłońska-Deptuła, Janina Gawrysiakowa, „Materiały do zaangażowania patriotycznego zakonów męskich w Królestwie Polskim w latach 1861-1864”, w: Materiaty do historii zgromadzeń zakonnych na ziemiach polskich $w$ XIX i poczatku XX wieku (Lublin, 1976), 107; Józef Raciborski, „Kościół i klasztor oo. Bernardynów”, Kronika Diecezji Kujawsko-Kaliskiej (1924), 10: 435; Norbert Golichowski, Przed nowa epoka. Materiały do historii oo. Bernardynów w Polsce (Kraków, 1899), 70-71; Sadok Barącz, Pamiętnik Zakonu WW. oo. Bernardynów $w$ Polsce (Lwów, 1874), 244-245. Jak przypuszcza Sławomir Przygodzki, nie brał czynnego udziału w powstaniu były gwardian konwentu kaliskiego i definitor prowincji Antoni Majewski, często przez historyków uważany za kapelana oddziału Cieszkowskiego. W świetle zachowanych archiwaliów Majewski w czasie powstania przebywał w klasztorze kaliskim, po kasacie zakonu nie opuścił klasztoru, tak jak sądził J. Raciborski, natomiast pełnił w kościele pobernardyńskim funkcję wikariusza i zmarł śmiercią naturalną w Kaliszu w 1865 r. Skromny majątek Majewskiego, nieco ponad 200 rubli, przeznaczony został na reparację kościoła. Kapłanem, który zginął w bitwie pod Grochowiskami 18 marca 1863 r., był noszący to samo imię i nazwisko reformat Antoni Majewski. Przygodzki, Losy bernardynów kaliskich i klasztoru w okresie zaborów (1793-1914), 70. 
Czynny udział w powstaniu wzięli również gwardian Sylwester Grzybowski ${ }^{46}$, wikariusz parafii w Chęcinach Wiktoryn Sikorski ${ }^{47}$, kapelan szpitala św. Aleksandra $\mathrm{w}$ Kielcach Martynian Maszewski ${ }^{48}$, spowiednik Kolumbin Tomaszewski, bracia zakonni Spirydion Stangierski ${ }^{49}$ i Pacyfik Juszko. Pod zarzutem głoszenia podburzających kazań stanęli po upadku powstania przed sądem January Kubarek ${ }^{50}$ i Walenty Lisowski ${ }^{51}$. Wikarego klasztoru Arseniusza Kawczyńskiego ${ }^{52}$ sądzono za poświęcenie krzyża w Łukowie w 1861 r., postawionego dla uczczenia pięciu poległych w Warszawie. Przez jakiś czas był on więziony w Warszawie. Bernardyni Grzybowski, Maszewski, Stangierski i Juszko zostali skazani na karne przeniesienie do klasztoru w Paradyżu (Wielkiej Woli), z tym że Grzybowski zapłacił ponadto 50 rubli kontrybucji. Sikorski został zesłany na osiedlenie do Kostromska i przeniesiony do Paradyża. 30 maja 1865 r. Lisowskiego skazano na miesiąc twierdzy

${ }^{46}$ Sylwester Grzybowski OFM urodził się w 1813 r., wstąpił do zakonu w 1832 r., święcenia prezbiteratu przyjął w 1844 r. W roku 1863 i 1864 był gwardianem na Karczówce. Do Paradyża przybył 30 XI 1864 r. Zmarł tamże 7 I 1877. Roland Prejs, „Bernardyni prowincji małopolskiej po kasacie 1864 r.”, Studia Franciszkańskie (1999), 10: 341; Jabłońska-Deptuła, Gawrysiakowa, „Materiały do zaangażowania patriotycznego zakonów", 103.

${ }^{47}$ Wiktoryn Sikorski OFM urodził się 1836 r., do zakonu wstąpił w 1856 r., święcenia prezbiteratu przyjął w $1861 \mathrm{r}$. Po interwencji proboszcza ks. Tomasza Batorskiego administracja państwowa zgodziła się na powrót Sikorskiego z Paradyża do Chęcin. Otrzymał indult sekularyzacyjny (1865) i przeszedł do diecezji kieleckiej. Zmarł 2 II 1916 jako administrator parafii Gorzków. Prejs, Bernardyni prowincji małopolskiej, 360; Jabłońska-Deptuła, Gawrysiakowa, „Materiały do zaangażowania patriotycznego zakonów", s. 110.

${ }^{48}$ Martynian Maszewski OFM urodził się 1835 r., do zakonu wstąpił w 1852 r., święcenia prezbiteratu przyjął w 1859 r.; w roku 1863 i 1864 był kaznodzieją na Karczówce, skąd przybył do Paradyża 30 XI 1864 r., gdzie został prokuratorem klasztoru. Otrzymał indult sekularyzacyjny w 1867 r. W diecezji kujawsko-kaliskiej został administratorem parafii Biała koło Częstochowy, gdzie zmarł 9 VI 1895. Prejs, „Bernardyni prowincji małopolskiej”, 352.

${ }^{49}$ Spirydion Stangierski OFM urodził się w 1831 r., do zakonu wstąpił w 1849 r. Był bratem zakonnym. Przeżył kasatę klasztoru w Paradyżu w 1893 r., skąd został wywieziony do Koła, gdzie zmarł 26 VI 1898 r. Prejs, „Bernardyni prowincji małopolskiej”, 361; Jabłońska-Deptuła, Gawrysiakowa, „Materiały do zaangażowania patriotycznego zakonów”, 111.

50 January Kubarek OFM urodził się w 1802 r., do zakonu wstąpił w 1830 r. W roku 1860 mieszkał na Karczówce. W latach 1861-1862 był kaznodzieją w Lublinie. Jabłońska-Deptuła, Gawrysiakowa, „Materiały do zaangażowania patriotycznego zakonów”, 105.

${ }^{51}$ Walenty (vel Wincenty) Lisowski OFM urodził się w 1822 r., do zakonu wstąpił w 1844 r. W roku 1861 był kaznodzieją na Karczówce. W latach 1863-1864 był przełożonym w Lublinie. Jabłońska-Deptuła, Gawrysiakowa, ,Materiały do zaangażowania patriotycznego zakonów”, 106.

${ }^{52}$ Arseniusz Kawczyński OFM urodził się 1831 r., do zakonu wstąpił w 1849 r., święcenia prezbiteratu przyjął w 1858 r. Był wikarym na Karczówce w latach 1862-1863. W roku 1864 został wikarym klasztoru w Paradyżu. Zmarł w Radomiu jako rektor pobernardyńskiego kościoła św. Katarzyny 12 II 1866 r. Prejs, „Bernardyni prowincji małopolskiej”, 344-345; Jabłońska-Deptuła, Gawrysiakowa, „Materiały do zaangażowania patriotycznego zakonów”, 104. 
w Modlinie, a potem oddano pod nadzór policyjny. Kubarka skazano na twierdzę w Zamościu, a następnie na wydalenie z Królestwa, Kawczyńskiego na więzienie ${ }^{53}$. Bernardyni przebywali na Karczówce do 28 listopada 1864 r. Wówczas to, na mocy ukazu Aleksandra II z 27 października 1864 r., za czynny udział zakonników w powstaniu styczniowym nastąpiła kasata klasztoru bernardynów na Karczówce w Kielcach. W chwili kasaty mieszkało w konwencie dziesięciu zakonników ${ }^{54}$. Po kasacie pozostawiony został przez władze zaborcze tylko jeden bernardyn Kolumbin Tomaszewski, rektor kościoła poklasztornego. Przez 50 lat był samotnym opiekunem kościoła i klasztoru. Zmarł 16 lutego 1914 r. i został pochowany na cmentarzu Nowym w Kielcach ${ }^{55}$.

Proboszcz rezydencji w Kobyłce pod Warszawą bernardyn Ubald Żukiewicz został oskarżony przez władze carskie o czynny udział w powstaniu styczniowym. Po kasacie rezydencji w 1864 r. parafię objął ksiądz diecezjalny ${ }^{56}$.

Bernardyni w Kole nad Wartą opiekowali się walczącymi o wolność, udzielali im schronienia. W czasie potyczki, stoczonej 6 maja 1863 r. na przedmieściach Koła, klasztor pełnił rolę lazaretu, w którym udzielano pomocy rannym powstańcom. Aleksander Gołębiewski, z rozkazu władz rządowych przeniesiony z Warszawy do Koła, kwestował dla powstańców żywność wśród okolicznej ludności. Skazano go na zsyłkę w głąb Rosji. Gwardianowi kolskiemu Walentemu Tercjakowi zarzucano, że wyrażał publicznie sympatie wobec powstania. Bonawentura Mańka zginął w bitwie pod Łazami

${ }^{53}$ Prejs, „Bernardyni w Królestwie Polskim po kasacie 1864 r.”, 436; tenże, „Klasztor bernardynów w Paradyżu (Wielkiej Woli) w latach 1864-1893. Przykład funkcjonowania klasztoru etatowego w Królestwie Polskim w warunkach pokasacyjnych”, Studia Franciszkańskie (2001), 11: 276, 277; Wyczawski, Bernardyni, t. 3: 186-188; Wiesław Murawiec, „Kielce”, w: Klasztory bernardyńskie w Polsce, 134-135; Józef Zdanowski, Karczówka pod Kielcami (Kielce, 1928), 17.

${ }^{54}$ Prejs, „Bernardyni prowincji małopolskiej”, s. 331; Piotr Paweł Gach, „Zakony franciszkańskie na ziemiach dawnej Rzeczypospolitej i Śląska w latach 1773-1914”, w: Zakony franciszkańskie w Polsce, t. 3. Franciszkanie w Polsce XIX wieku, red. Jerzy Kłoczowski, Niepokalanów 1996, s. 31; Wyczawski, Bernardyni, t. 3: 191; Murawiec, „Kielce”, w: Klasztory bernardyńskie w Polsce, 135; Zdanowski, Karczówka pod Kielcami, 17; Kantak, Bernardyni, t. 2: 547.

${ }^{55}$ Kolumbin Tomaszewski OFM urodził się w 1829 r., wstąpił do zakonu w 1846 r., święcenia prezbiteratu przyjął w 1853 r. N. Golichowski, za nim W. Murawiec podaje błędnie: Kolumbin Piotrowski. Aleksander Krzysztof Sitnik, „W 390 rocznicę fundacji kościoła pw. św. Karola Boromeusza na Karczówce w Kielcach (1624-2014)”, Przegląd Kalwaryjski (2014), 18: 129; Prejs, „Bernardyni prowincji małopolskiej”, 365; tenże, „Bernardyni w Królestwie Polskim po kasacie 1864 r.”, 469; Murawiec, „Kielce”, w: Klasztory bernardyńskie w Polsce, 135; Jabłońska--Deptuła, Gawrysiakowa, „Materiały do zaangażowania patriotycznego zakonów”, 113; Zdanowski, Karczówka pod Kielcami, 18; Golichowski, Przed nowa epoka, 71.

${ }^{56}$ Hieronim Eugeniusz Wyczawski, „Kobyłka”, w: Klasztory bernardyńskie w Polsce, 140. 
23 marca 1863 r., istnieją jednak wątpliwości, czy był on członkiem kolskiej wspólnoty. Konwent w Kole nie uległ kasacie. Zaliczono go do rzędu tzw. klasztorów etatowych. Przy końcu 1864 r. przywieziono do Koła bernardynów z klasztorów św. Anny i Czerniakowa w Warszawie oraz Góry Kalwarii. W 1893 r. przybyli do Koła bernardyni z Paradyża i Widawy, w 1898 r. z Warty i Kazimierza Biskupiego. Bernardyni kolscy przez cały czas dbali o dobry stan swojej biblioteki. Klasztor w Kole był ostatnią placówką niegdyś prężnie działającej zakonnej prowincji wielkopolskiej. Ostatni kolski bernardyn Franciszek Czachorowski (zm. 9 grudnia 1919) doczekał czasów niepodległej Polski. Miał szczęście powitać pod koniec 1918 r. w murach kolskiego klasztoru bernardynów przysłanych ze Lwowa w celu obsadzenia nowymi zakonnikami wymierającego konwentu ${ }^{57}$.

Klasztor bernardynów w Lublinie w czasie powstania styczniowego stanowił ośrodek działalności politycznej, gdzie werbowano ochotników, odbierano przysięgi i kierowano do oddziałów, udzielano schronienia i zasiłków. Jacenty Lewczuk został za „bardzo podburzające” kazanie, wygłoszone 28 lipca 1863 r. w lubelskim kościele dominikanów, wywieziony 24 października 1863 r. do guberni saratowskiej. Klasztor został skasowany. W nocy z 27 na 28 listopada 1864 r. przewieziono bernardynów lubelskich do klasztoru w Paradyżu. Konsystorz lubelski oddał kościół pod zarząd mianowanego rektorem bernardyna Hieronima Willamowicza. Klasztor został częściowo zajęty przez rektora, a resztę przeznaczono na potrzeby zarządu miejskiego. Biblioteka klasztorna, licząca 2640 woluminów, porzucona w nieładzie, została częściowo rozgrabiona. Dopiero w 1875 r. ocalałą część przewieziono do seminarium duchownego $\mathrm{w}$ Lublinie ${ }^{58}$.

Bernardyni łęczyccy czynnie zaangażowali się w walkę narodowo-wyzwoleńczą w czasie powstania styczniowego. W latach 1863-1864 klasztor stanowił oparcie dla powstańców. Gwardian Salwator Sikorski zezwolił powstańcom

${ }^{57}$ Aleksander Krzysztof Sitnik, „Udział bernardynów kolskich w powstaniu styczniowym i ich późniejsze losy”, w: Powstanie styczniowe na ziemi kolskiej - w 150. rocznice zrywu narodowego, red. Krzysztof Witkowski (Koło, 2013), 81-96; Piotr Gołdyn, „Klasztor w Kole w okresie powstania styczniowego i po jego upadku", w: Bernardyni w Kole, wyd. Muzeum Technik Ceramicznych w Kole (Koło, 2006), 10-20; tenże, Franciszkanie w powstaniu styczniowym na ziemi konińskiej (Konin, 2002), 30, 40, 48; Aleksander Krzysztof Sitnik, „Księgozbiór klasztoru oo. Bernardynów w Kole nad Wartą (II połowa XV - I połowa XX wieku)", w: Królewskie miasto Kolo. Studia w 650. rocznice lokacji miasta, red. Izabela Skierska (Koło, 2012), 215-234; Wyczawski, Bernardyni, t. 3: 165; Kajetan Grudziński, „Koło”, w: Klasztory bernardyńskie w Polsce, 145.

${ }^{58}$ Wyczawski, Bernardyni, t. 3: 187; Augustyn Chadam, „Lublin”, w: Klasztory bernardyńskie $w$ Polsce, 192. 
na złożenie przysięgi w kościele klasztornym. Został za to zesłany w $1864 \mathrm{r}$. do Kostromska. Wikary klasztoru Rafał Staszakowski był dowódcą jednego z oddziałów powstańczych. Zginął od kuli pod Dobrzykowem. Poniósł śmierć w czasie udzielania sakramentów rannemu żołnierzowi. Kaznodzieja Filip Markowski, jako kapelan oddziału Dzieci Warszawy, walczył z bronią w ręku. W walkach powstańczych wziął udział Eugeniusz Zychowicz. Po upadku powstania zbiegł za granicę. Spowiednik Innocenty Jabłoński został oskarżony o sympatyzowanie z powstańcami i oddany pod nadzór policji. Konsekwencją działalności patriotycznej bernardyńskich zakonników była kasata klasztoru w 1864 roku. Bernardyni zostali skierowani do klasztoru etatowego w Widawie. Zarząd nad kościołem przejęli księża diecezjalni z łęczyckiej parafii ${ }^{59}$.

Zakonnicy z klasztoru łukowskiego koło Siedlec już w latach 1861-1862 zaangażowali się w działalność patriotyczną. Dwóch kapłanów było z tego powodu więzionych w Modlinie i Warszawie. Brali również czynny udział w czasie powstania styczniowego. Firmin Mędrkiewicz za czynny udział w powstaniu został aresztowany w Warszawie. Klasztor skasowano 2 października 1864 r. Bernardynów przewieziono do etatowego klasztoru w Paradyżu. Ksiądz diecezjalny został rektorem kościoła i zajął część klasztoru, resztę zaś oddano na mieszkania prywatne. Bibliotekę klasztorną odwieziono dopiero w $1871 \mathrm{r}$. do seminarium duchownego w Lublinie, stąd część książek do momentu wywózki skradziono ${ }^{60}$.

Również klasztor bernardynów w Opatowie odegrał pewną rolę w powstaniu styczniowym. Brał w nim czynny udział Innocenty Tygiński. Między innymi 8 lutego 1863 r. odprawił on uroczyste nabożeństwo patriotyczne z okazji zaprzysiężenia ziemian, chłopów i zarządów gminnych powiatu opa-

${ }^{59}$ Aleksander Krzysztof Sitnik, Tomasz Sitnik, Bernardyni łęczyccy. Dzieje klasztoru i kościoła pw. Niepokalanego Poczęcia NMP oo. Bernardynów w Lęczycy (1632-1864, od 1946) (Kalwaria Zebrzydowska, 2006), 73; Ryszard Rosin, Stefan Pytlas, Krzysztof Woźniak, „Lata zaborów”, w: Łęczyca. Monografia miasta do 1990 roku, red. Ryszard Rosin (Łęczyca, 2001), 246, 319-320; Dorota Dąbrowska, „OO. Bernardyni w Łęczycy”, Posłaniec Bernardyński (2000), 2: 10; Wyczawski, Bernardyni, t. 3: 165, 166, 168, 171; tenże, „Łęczyca”, w: Klasztory bernardyńskie w Polsce, 199; Jabłońska-Deptuła, Gawrysiakowa, „Materiały do zaangażowania patriotycznego zakonów", 105, 110-111; Kubicki, Bojownicy kapłani, cz. 1, t. 1: 215; tamże, cz. 1, t. 3: 631, 639; Kantak, Bernardyni, t. 2: 523, 544, 547; [Wacław Płonka], Kościót i klasztor oo. Bernardynów $w$ Łęczycy, Nakładem Komitetu Odnowienia Kościoła i Klasztoru ([Łęczyca], 1947), 14; Michał Rawicz-Witanowski, Monografia Łęczycy (Kraków, 1898), 135; APBK rkps W-67, Archivum conventus Varthensis sub titulo Beatissimae Virginis Mariae Assumptae in archidioecesi Gnesnensi in palatinatu et districtu Sieradiensi (1457-1870), 77.

${ }^{60}$ Augustyn Chadam, „Łuków”, w: Klasztory bernardyńskie w Polsce, 214. 
towskiego. W klasztorze leczyli się i przechowywali ranni powstańcy. Przy końcu 1864 r. klasztor został skasowany. Do klasztoru etatowego w Paradyżu przewieziono następujących zakonników: gwardiana Dionizego Schönweitza, Aleksego Zienkiewicza, Anastazego Gilewicza i braci zakonnych: Grzegorza Łukasika, Bernardyna Iżyłowskiego i Izaaka Kossakowskiego. Gwardianowi po wielu zabiegach udało się otrzymać paszport na wyjazd do Galicji. Zmarł 1 stycznia 1869 r. w Krzeszowicach, gdzie pełnił obowiązki kapelana szpitalnego. W Opatowie pozostawiono bernardyna Henryka Kierszulisa do opieki nad kościołem. Biblioteka klasztorna, obejmująca w chwili kasaty jeszcze ponad 1000 tomów, została w 1865 r. z rozporządzenia biskupa sandomierskiego Józefa Juszyńskiego przekazana do seminarium duchownego w Sandomierzu. Wśród inkunabułów znajdowały się dwa, pochodzące z 1497 r. z notami proweniencyjnymi bł. Władysława z Gielniowa (sygn. Inc. 125 i Inc. 137) ${ }^{61}$.

Skład personalny klasztoru bernardynów w Ostrołęce w 1863 r. wyglądał następująco: gwardian Tadeusz Lange, wikary Melchior Meller, kaznodzieje Fortunat Bereszczyński, Leonard Jabłoński, Serafin Jackiewicz i Antoni Spiro, lektor teologii Leonard Pietruszewski oraz bracia zakonni Franciszek Bałaziński i Roger Rogoziński. Bernardyni wzięli udział w powstaniu styczniowym. Przykładem ilustrującym tę opinię było zaangażowanie powstańca Adama Wojciechowskiego z Ostrołęki oraz młodego bernardyna, którzy przemycali sztucery belgijskie przez granicę pruską w okolicach Myszyńca. Wprawdzie nie znamy nazwiska bernardyna, ale jest wielce prawdopodobne, że był to bernardyn z Ostrołęki. Raport naczelnika wojennego z Płocka z 21 lipca 1864 r., który posłużył do sporządzenia tzw. raportu Czerkaskiego, wymienia bernardynów Melchiora Mellera i Leonarda Jabłońskiego, którzy po przeprowadzeniu dochodzenia zostali zwolnieni z aresztu i oddani pod nadzór policyjny. Aresztowani 23 grudnia 1863 r., jeszcze w kwietniu 1864 r. przebywali razem w więzieniu w Pułtusku. W końcu zostali zesłani na Syberię. Kaznodzieja Fortunat Bereszczyński był kapelanem powstańców. Ponadto został oskarżony przed biskupem płockim Wincentym Popielem o to, że udzielał sakramentów rannym powstańcom. Za działalność został zatrzymany przez Rosjan. Zaangażowany w działalność patriotyczną był również kaznodzieja Antoni Spiro. Podczas rewizji klasztoru odkryto w jednym z korytarzy tarczę strzelecką narysowaną na drzwiach, na której znajdowały się ślady po niewielkich kulach. Naczelnik wysnuł stąd wniosek, że w klasztorze odbywała się nauka strzelania. Oprócz tego odnaleziono w nim niewielką ilość ołowiu

\footnotetext{
${ }^{61}$ Kajetan Grudziński, „Opatów”, w: Klasztory bernardyńskie w Polsce, 243.
} 
do produkcji kul. Jak głosi lokalna tradycja, „w podziemiach klasztoru bernardynów zgromadzono trochę broni i amunicji. Rosjanie podejrzewali mieszczan o akcję konspiracyjną i dlatego planowali przeprowadzenie rewizji w klasztorze. Wobec tego konspiratorzy w obawie większej «wpadki» zmuszeni byli broń tę usunąć. Pod jakimś wymyślonym pozorem ogłoszono $\mathrm{z}$ ambony konieczność usunięcia $\mathrm{z}$ podziemi klasztornych zwłok jednego z zakonników. Kilka wtajemniczonych osób, jako delegacja mieszczan, udało się do komendanta rosyjskiego garnizonu z prośbą o zezwolenie na ekshumację zwłok zakonnika. Po otrzymaniu zezwolenia wydobyto trumnę «mnicha», odprawiono egzekwie i przeniesiono ją uroczyście na cmentarz. Przeprowadzona w kilka dni później rewizja w klasztorze broni nie odnalazła". W klasztorze zakonnicy przyjmowali przysięgi i werbowali powstańców. W konsekwencji klasztor uległ kasacie. Relację z tej akcji znajdujemy w raporcie naczelnika wojennego w Ostrołęce majora Kryckiego. Raport wpłynął do generała policmajstra Trepowa w Warszawie odpowiedzialnego za przeprowadzenie kasaty. Naczelnik otrzymał rozkaz wkroczenia do klasztoru i wykonania ukazu carskiego o godzinie 22 w nocy z 27/28 (15/16) listopada 1864 r. Wezwał burmistrza Zygmunta Butkiewicza, ostrołęckiego dziekana ks. Mariana Skowrońskiego i naczelnika miejscowej żandarmerii. Z niezbędną ilością żołnierzy, którzy otoczyli zabudowania, udał się do klasztoru. Tam, zebrawszy w refektarzu zakonników, przeczytał im ukaz i oznajmił, że klasztor zostaje zamknięty. Naczelnik pytał, czy ktoś z zakonników zamierza wyjechać za granicę. Gdy nikt nie wyraził chęci, zaczął spisywać zastane mienie, jednak spisu takiego ostatecznie nie sporządzono z powodu braku czasu. Poinformował również, że w klasztorze pozostanie ojciec Antoni Spiro, który ma obowiązek pilnować przedmiotów gospodarstwa należącego do klasztoru oraz przedmiotów liturgicznych pozostających w zakrystii. Przy okazji znalezione zostały pieniądze (1771 rubli i 50 kopiejek), które zabezpieczono i oddano w depozyt do naczelnika wojskowego. Wprawdzie gwardian Tadeusz Lange oznajmił, że znaczna ich część (1735 rubli) stanowi jego własność, ale w związku z tym, że nie można było tego udowodnić, pieniądze oddano w depozyt. Podobny los spotkał dokumenty klasztorne, które zostały opieczętowane i również zdeponowane u naczelnika wojennego. Nad ranem 28 (16) listopada zakonnicy, pod eskortą pięciu kozaków i czterech żołnierzy z pułku piechoty pod dowództwem porucznika von Zorka z 24 Simbirskiego Pułku Piechoty, zaopatrzonego w niezbędne pisma i pieniądze, zostali odprawieni do Czyżewa. Z dziewięciu zakonników z ostatniego składu ostrołęckiego konwentu rankiem 28 listopada eskortowano jedynie pięciu: ojców Tadeusza 
Langego, Melchiora Mellera, Leonarda Pietruszewskiego, Serafina Jackiewicza oraz brata zakonnego Franciszka Bałazińskiego. Ojciec Fortunat Bereszczyński, nieobecny w czasie zamknięcia klasztoru, po przybyciu do Ostrołęki został odprawiony w ślad za grupą i dołączył do niej w Ostrowi Mazowieckiej, natomiast brat Roger Rogoziński miał być odprawiony tuż po powrocie. Nie wiemy, gdzie w tym czasie przebywał ojciec Leonard Jabłoński. Po opuszczeniu murów klasztornych przez zakonników naczelnik Krycki wraz z burmistrzem i dziekanem zaczęli spisywać majątek pobernardyński. Tymczasem zakonnicy przez Czyżewo i Ostrów Mazowiecką udali się koleją do Warszawy. W Czerniakowie, w klasztorze pobernardyńskim, który był miejscem zbornym, mieli się zdecydować, czy wyjeżdżają za granicę. Żaden $\mathrm{z}$ bernardynów ostrołęckich nie wyraził na to chęci. W tej sytuacji po dwóch dniach o szóstej rano 2 grudnia (20 listopada) 1864 r. opuścili punkt zborny i zostali konwojowani przez oficera pociągiem do klasztoru etatowego do Kazimierza Biskupiego. 4 grudnia (22 listopada) dołączył do nich brat zakonny Roger Rogoziński. Biblioteka klasztorna została przewieziona do seminarium duchownego diecezji płockiej. Na przewiezienie biblioteki z Ostrołęki konsystorz wyznaczył 50 rubli: 35 rubli za transport i 15 rubli za załadowanie i rozładowanie ${ }^{62}$.

Ukaz kasacyjny w 1864 r. oszczędził klasztor bernardyński w Paradyżu (Wielkowoli) koło Opoczna, choć w czasie powstania styczniowego był on ośrodkiem konspiracji powstańczej. Brat zakonny Eliasz Brylski, kwestarz, był za udział w powstaniu sądzony przez sąd polowy i skazany na więzienie w cytadeli. Klasztor został uznany przez władze carskie za klasztor etatowy, w którym zgromadzono trzydziestu zakonników ${ }^{63}$.

Za udział w ruchach wolnościowych został skasowany klasztor bernardynów w Piotrkowie Trybunalskim w nocy 27/28 listopada 1864 r. Do klasztoru etatowego w Warcie zostali przewiezieni: gwardian Piotr Rzepa, Kornel Żuchowski, Benon Skórczyński, Czesław Gołębiowski, Pius Kulczyński, klerycy Hieronim Domagalski, Emilian Grewkowicz, Terencjan Guddat, Stanisław Kulkowski, Inocenty Sarnowicz, Eustachy Wasilewski, Juwenalis Krajewski, Fidelis Kaczorkiewicz, Andrzej Szczęsny, Liboriusz Wałczyński

${ }^{62}$ Barbara Kalinowska, Bernardyni w Ostrołęce, 1664-1864 (Ostrołęka, 2011), s. 319-322, 336, 337, 339-340, 352-353, 373; Taż, Kasata zakonów w Królestwie Polskim, 41; Wyczawski, Bernardyni, t. 3: 166.

${ }^{63}$ Roland Prejs, „Klasztor bernardynów w Paradyżu (Wielkiej Woli) w latach 1864-1893. Przykład funkcjonowania klasztoru etatowego w Królestwie Polskim w warunkach pokasacyjnych", Studia Franciszkańskie (2001), 11: 275-305; Wyczawski, Bernardyni, t. 3: 191; Andrzej Pabin, „Paradyż”, w: Klasztory bernardyńskie w Polsce, 254. 
oraz bracia zakonni Ubald Katarzyński, Seweryn Mikulski. Cyprian Lipiński i Honoriusz Sienkiewicz, przebywający wówczas z pomocą duszpasterską w parafiach, oraz bracia zakonni Gracjan Frankowski i Lucjan Sadowski, którzy wyjechali na kwestę, uniknęli losu współbraci. Do opieki nad kościołem władze carskie pozostawiły Cyryla Malinowskiego i brata zakonnego Benedykta Kwiatkowskiego, organistę. W 1867 r. usunięto ich, a na rektora kościoła powołano księdza diecezjalnego. W budynku klasztornym po kasacie umieszczono archiwum akt dawnych i guberialnych, drukarnię i redakcję „Gubernialnych Wiadomości”, następnie areszt policyjny. Tablica marmurowa znajdująca się obecnie w kościele bernardyńskim w Piotrkowie Trybunalskim, upamiętniająca udział bernardynów w powstaniu styczniowym, poświęcona została pamięci Zefiryna Strupczowskiego, gwardiana klasztoru piotrkowskiego, który zginął pod Rychłocicami koło Wielunia 19 maja 1863 r., niosąc pomoc duszpasterską powstańcom. Według informacji, zamieszczonej na tablicy, w klasztorze w czasie powstania styczniowego odbywały się posiedzenia dowódców tajnej organizacji powstańczej ${ }^{64}$.

W Przasnyszu został schwytany 20-letni diakon bernardyński Cyryl Skalski (vel Cyriak Cygalski). Za działalność powstańczą został najpierw zesłany „w sołdaty”. Ponieważ nie chciał złożyć przysięgi na wierność carowi, w listopadzie 1863 r. został skazany na zesłanie w głąb Rosji. W 1876 r. przebywał w Usting w guberni wołogodzkiej. Gwardian Paschalis Błażejewski przed 1863 r. był dwukrotnie karany po przeniesieniu go do Świętej Anny za bliżej nieznane przewinienia polityczne w Przasnyszu. Spowiednik Szymon Cebula, kaznodzieja Narcyz Rozbachowski, Symplicjan Lesisz oraz kleryk Anzelm Czaplicki uciekli z klasztoru do powstania. Cebula był kapelanem w oddziale Edmunda Taczanowskiego, mianowany pułkownikiem i dowódcą oddziału, po upadku powstania uszedł za granicę. Leopold Śmigielski i Emil Śniegocki zostali ukarani: pierwszy zesłaniem na Syberię za udzielenie sakramentów katoliczce wychodzącej za mąż za prawosławnego, drugi oddaniem pod dozór policyjny za nieprawomyślność. 28 listopada 1864 r. dziekan przasnyski donosił biskupowi płockiemu W. Popielowi, że w dniu 27 listopada o godz. 21 został wezwany do naczelnika wojennego powiatu płockiego. Po przybyciu udał się wraz z naczelnikiem i innymi urzędnikami do klasztoru

\footnotetext{
${ }^{64}$ Jerzy Kukulski, „Historia klasztoru i kościoła oo. Bernardynów w Piotrkowie Trybunalskim”, w: Królowa ziemi piotrkowskiej, red. Dawid Czesław Postawa (Kraków, 2011), 47-48; Aleksander Krzysztof Sitnik, „Akta klasztoru i kościoła oo. Bernardynów w Piotrkowie Trybunalskim w zasobie Archiwum Prowincji oo. Bernardynów w Krakowie", w: Królowa ziemi piotrkowskiej, 125; Kajetan Grudziński, „Piotrków Trybunalski”, w: Klasztory bernardyńskie w Polsce, 263.
} 
bernardynów w Przasnyszu. Po zebraniu wszystkich zakonników odczytano im ukaz carski zawiadamiający o skasowaniu klasztoru. Zakonnikom pozostawiono do wyboru pozostanie w kraju lub wyjazd za granicę. Dano im dwie godziny na zabranie swoich rzeczy i oświadczono, że zostaną wywiezieni do Warty. Klasztor skasowano i przekazano pod administrację jedynemu zatrzymanemu w Przasnyszu bernardynowi Walerianowi Wojciechowskiemu. Po jego śmierci klasztor przejęli księża diecezjalni. Część klasztornej biblioteki została przekazana do seminarium diecezjalnego w Płocku, część została rozproszona ${ }^{65}$.

Bernardyn Benwenuty Mańkowski głosił kazania patriotyczne przy przydrożnych kaplicach do pielgrzymów udających się na Jasną Górę. Przynależał on do klasztoru w Przyrowie (Święta Anna) koło Częstochowy. W czasie powstania styczniowego został kapelanem oddziału pułkownika Teodora Cieszkowskiego. Zginął pod Łazami w powiecie olkuskim 22 marca 1863 r., gdy z krzyżem w ręku błogosławił idących do ataku powstańców ${ }^{66}$. Pełniący w tym czasie w Świętej Annie obowiązki gwardiana Paschalis Błażejewski był notowany w aktach carskiej policji z powodu swej patriotycznej postawy. W murach klasztoru bernardyni ukrywali powstańczego naczelnika województwa krakowskiego Zygmunta Chmielińskiego. Dowodził on oddziałem między innymi w bitwie pod Bodzechowem 16 grudnia 1863 r., gdzie został ciężko ranny i pojmany przez kozaków. Odstawiony do Radomia wyrokiem sądu wojskowego, został skazany na śmierć i rozstrzelany 23 grudnia $1863 \mathrm{r}$. W nocy z 27/28 listopada 1864 r. klasztor w Świętej Annie został skasowany. Zakonnicy zostali przewiezieni do klasztoru etatowego w Widawie. Jeden z bernardynów, Wawrzyniec Jaracz, zdołał w czerwcu 1865 r. wydostać się za granicę. W klasztorze w Świętej Annie pozostał do obsługi kościoła były prowincjał Franciszek Morański, gdzie przebywał do swojej śmierci 4 stycznia 1868 r. Następnie kościołem opiekowali się księża diecezjalni. Po kasacie klasztor zajmowało wojsko rosyjskie. W 1869 r. ustąpiło

\footnotetext{
${ }^{65}$ Michał Marian Grzybowski, „Duchowieństwo katolickie diecezji płockiej w okresie powstania styczniowego", Rocznik Towarzystwa Naukowego Plockiego (2013), 5: 41; Kalinowska, Kasata zakonów w Królestwie Polskim, 41; Wyczawski, Bernardyni, t. 3: 167; tenże, „Przasnysz”, w: Klasztory bernardyńskie w Polsce, 277; Murawiec, Bernardyni warszawscy, 185; Grudziński, Bernardyni w stużbie ojczyzny, 113, 120; APBK rkps I-ł-12, Wykaz alfabetyczny, s. 15.

${ }^{66}$ Wiesław Franciszek Murawiec, „Mańkowski”, w: Polski słownik biograficzny, t. 19 (1974), 514; tenże, „Mańkowski”, w: Stownik polskich pisarzy franciszkańskich, red. Hieronim Eugeniusz Wyczawski (Warszawa, 1981), 306-307; Kajetan Grudziński, „Święta Anna (Przyrów), w: Klasztory bernardyńskie w Polsce", 365; Kantak, Bernardyni, t. 2: 542-543; Narcyza Żmichowska, Listy, t. 2 (Wrocław, 1960), s. 232; Agaton Giller, Polska w walce, t. 1 (Paryż, 1868), 38.
} 
z klasztoru, aby zrobić miejsce dla przywiezionych szesnastu dominikanek ze skasowanego ich klasztoru w Piotrkowie Trybunalskim i pięciu mariawitek ze zlikwidowanego klasztoru w Częstochowie ${ }^{67}$.

W czasie powstania styczniowego pułkownik Marcin Borelowski, jako naczelnik wojenny województw lubelskiego i podlaskiego, dowodził jednym z oddziałów. 24 marca 1863 r. został pokonany w bitwie pod Krasnobrodem, 30 maja zaskoczony przez Rosjan odparł ich atak w bitwie pod Chruśliną i odniósł zwycięstwo 3 września w bitwie pod Panasówką. 6 września poległ w bitwie pod Batorzem. W 1863 r. powstańcy z oddziału Borelowskiego ukryli na pewien czas w klasztorze bernardynów w Radecznicy swoich rannych. O nieprawomyślność oskarżyły władze Konrada Cerana, klasztoru władze carskie jednak nie skasowały w 1864 r. $^{68}$

Klasztor bernardynów w Radomiu, który tak żywo reagował na wydarzenia warszawskie z 1861 r., również w czasie powstania styczniowego stał się oparciem dla powstańców. Według ustaleń Osobnej Komisji Rządowej Włodzimierza Czerkawskiego do najbardziej zaangażowanych w powstaniu należeli: gwardian Telesfor Zaborek, Roch Klimkiewicz i Paulin Domański oraz zakrystian brat zakonny Florian Szymański. Klimkiewicz i Domański zostali zesłani w głąb Rosji. Według autora Spisu Klimkiewicz przebywał w 1876 r. w Cywilsku w guberni kazańskiej, zaś Domański w 1880 r. w Usmani w guberni tambowskiej. Ponadto bernardyn z Radomia Jacek Lewczak przebywał w 1877 r. w guberni saratowskiej, ale nie wiadomo bliżej, kiedy miało miejsce jego aresztowanie. Brat zakonny Szymański był więziony przez trzy miesiące. Kapłani Martynian Maszewski, Rogery Kaznowski, Teofil Trojanowski, Letus Śniegocki oraz bracia zakonni Cyprian Kotowicz i Jakub Stąporkiewicz, według autora raportu rządowego, byli również czynnie zaangażowani $\mathrm{w}$ powstaniu. Poza tym klerycy filozofii w Radomiu, po zesłaniu lektora Paulina Domańskiego i gwardiana Zaborka, opuścili klasztor i przyłączyli się do powstania. Byli to: Modest Dziemiańczyk, Hugolin Rejniowicz, Felicjan Trzaskowski oraz Izydor Woźniacki. Z początkiem lipca 1863 r. zabudowania klasztorne zajęło wojsko carskie. W klasztorze założono tymczasowe więzienie dla aresztowanych za udział w powstaniu. Bernardyni

${ }^{67}$ Wyczawski, Bernardyni, t. 3: 169; Kajetan Grudziński, „Święta Anna”, w: Klasztory bernardyńskie w Polsce, 369, 370.

${ }^{68}$ Roland Prejs, „Klasztor bernardynów w Radecznicy w latach 1864-1919”, w: Na tym miejscu chwała Boga Najwyższego odprawiać się będzie... W setna rocznicę rewindykacji klasztoru oo. Bernardynów w Radecznicy (1919-2019), red. Iwo Mirosław Janusz, Aleksander Krzysztof Sitnik (Kalwaria Zebrzydowska, 2019), 117-132; Wyczawski, Bernardyni, t. 3: 188; Augustyn Chadam, „Radecznica”, w: Klasztory bernardyńskie w Polsce, 287. 
radomscy byli przez ten czas kontrolowani w swej pracy duszpasterskiej przez wojsko. Nocą z 27/28 listopada 1864 r. dokonano kasaty klasztoru. Bernardynów wywieziono do etatowego klasztoru w Paradyżu. Byli to następujący ojcowie: Rogery Kaznowski, Letus Śniegocki, Antoni Komendacki, klerycy Hugolin Rajniewicz, Augustyn Juszczak, Izydor Woźniacki, Felicjan Wrzaskowski, Modest Dziemiańczyk, Nikodem Filipowicz oraz bracia zakonni Remigiusz Starachowski, Cyprian Kotowicz, Jakub Stąporkiewicz, Michał Adamski. Zgodnie z praktyką, stosowaną przez władze carskie, pozostawiono w Radomiu dla opieki nad kościołem dwóch kapłanów, Teofila Trojanowskiego i Salwatora Kaczorowskiego oraz brata zakonnego zakrystiana Czesława Wolskiego. Oprócz wyżej wymienionych za wiedzą władz pozostał na krótko w Radomiu gwardian Benedykt Piotrowski, może celem załatwienia jakichś ważnych spraw klasztornych. Od prezydenta miasta otrzymał następnie propozycję wyjazdu za granicę albo do Paradyża, ostatecznie jednak, na podstawie zezwolenia naczelnika wojennego guberni radomskiej z 9 grudnia 1864 r., zamieszkał w miejscowości rodzinnej w Chlewiskach koło Opoczna. Kiedy pozostawiony w Radomiu o. Teofil Trojanowski zmarł 31 października 1865 r., pozwolono osiąść przy bernardyńskim kościele o. Arseniuszowi Kawczyńskiemu, wypuszczonemu z więzienia w Warszawie, gdzie odsiadywał karę za czynny udział w manifestacjach narodowych w Łukowie. W międzyczasie drugi kapłan, pozostawiony przy kościele, Kaczorowski, musiał opuścić Radom. Po śmierci Kawczyńskiego 10 lutego 1866 r. władze zaborcze nie pozwoliły już, aby inny bernardyn zajął miejsce zmarłego. Odtąd opiekę nad kościołem przejęli księża diecezjalni. Jest znamienne, że niedługo po kasacie klasztoru, bo w 1867 r., władze zaborcze zniosły istniejące przy kościele bernardynów od trzech przeszło wieków bardzo żywotne bractwo św. Anny, dlatego że jego członkowie na równi $\mathrm{z}$ bernardynami brali czynny udział w manifestacjach narodowych. Biblioteka klasztorna, licząca około 2000 woluminów, została po kasacie przewieziona do seminarium duchownego w Sandomierzu ${ }^{69}$.

${ }^{69}$ Elżbieta Orzechowska, „Bernardyni radomscy w życiu narodu polskiego w XIX wieku”, w: Wpisani w dzieje Radomia. Pięćset pięćdziesiąta rocznica przybycia oo. Bernardynów do Radomia (1468-2018), red. Michał Krawczyk, Aleksander Krzysztof Sitnik (Kalwaria Zebrzydowska, 2018), 133-182; taż, Radomscy bernardyni w dobie powstania styczniowego (Radom, 2008), 119; taż, „Z działalności patriotycznej bernardynów w Radomiu w dobie powstania styczniowego", w: Zakony franciszkańskie w Polsce, t. 3. Franciszkanie w Polsce w XIX wieku (Niepokalanów, 1996), 149-161; Murawiec, Zaangażowanie patriotyczne zakonników franciszkańskich, 315; tenże, Bernardyni warszawscy, 185; Wyczawski, Bernardyni, t. 3: 190; Kajetan Grudziński, „Radom”, w: Klasztory bernardyńskie w Polsce, 297, 298, 299; APBK rkps I-ł-12, Wykaz alfabetyczny, 3, 5, 7. 
Po upadku powstania styczniowego carskie władze śledcze oskarżyły bernardynów w Ratowie koło Mławy o sympatyzowanie z przedpowstaniowymi manifestacjami narodowymi i ruchem powstańczym. Wśród oskarżonych znaleźli się: Franciszek Cichocki, Apolinary Gawęcki, Piotr Kaliściński, Augustyn Kozłowski (zm. w 1883 r. w opinii świętości), Symforian Napiórkowski, Augustyn Sobociński i brat zakonny Roman Maltazar. Bernardyn Fidelis Meller dostarczał powstańcom rozkazy wojskowe i raporty. Brał udział w bitwach pod Brzezinami i Łoktą. Nie sądzono go, ponieważ nie dał się rozpoznać. U Sobocińskiego znaleziono przy rewizji zakazane wiersze, za co ukarano go grzywną w wysokości 42 rubli. Emila Śniegockiego oskarżono o nieprawomyślność i oddano pod nadzór policyjny. Pomimo oskarżeń o sympatie dla powstania konwentu w Ratowie nie skasowano. Zniesiono go dopiero w $1868 \mathrm{r}^{70}$

W klasztorze bernardynów w Skępem, w diecezji płockiej, istniał ośrodek powstańczy na cały powiat lipnowski. Rezydowała tam powstańcza żandarmeria, wymierzająca kary za zdradę i donosicielstwo. W kościele klasztornym odbierano przysięgi powstańcze od nowo zwerbowanych ochotników i wygłaszano płomienne kazania patriotyczne do pielgrzymów. Kaznodzieja Witalis Dobski (vel Dobrski) był silnie związany z ruchem powstańczym. Wsławił się odprawianiem publicznych nabożeństw za poległych manifestantów i głoszeniem patriotycznych kazań, śpiewaniem powstańczych pieśni, odbieraniem przysięgi powstańczej, za co został oskarżony wraz z innymi zakonnikami. Postulowano usunięcie go z tych stron ,gdzieś daleko”, pomimo to pozostał on po kasacie klasztoru w 1864 r. do obsługi kościoła. Wraz z nim pozostali Franciszek Sobalski i Piotr Celestyn Ślesiński (1864-1866). Liczącego 86 lat Amanda Sobiechowskiego pozostawiono w klasztorze do decyzji władz. Kasata klasztoru odbyła się w następujący sposób: w nocy z 27 na 28 listopada 1864 r. dość liczny oddział wojska przybył z Lipna do Skępego. Żołnierze otoczyli klasztor. Bernardynów zbudzono, zebrano wszystkich w refektarzu i odczytano ukaz carski z 8 listopada 1864 r. o zamknięciu klasztorów w Królestwie Polskim i ustawy dopełniające ukaz. Zakonnikom podano do wiadomości, że kto chce wyjechać za granicę, ten w myśl paragrafu 38 ukazu otrzyma za darmo paszport i pieniądze na podróż, żaden z zakonników jednak się nie zgłosił. Następnie sporządzono spis zakonników

\footnotetext{
${ }^{70}$ Stefan Marek Chrzanowski, Kościót i klasztor pobernardyński pod wezwaniem św. Antoniego $z$ Padwy w Ratowie (1686-1868) (Ratowo-Żuromin, 2014), 42-44; tenże, „Manifestacje patriotyczne i powstanie styczniowe w cieniu ratowskiego klasztoru bernardynów", Przegląd Kalwaryjski (2012-2013), 16-17: 27-33; Wyczawski, Bernardyni, t. 3: 167; tenże, „Ratowo”, w: Klasztory bernardyńskie w Polsce, 302; Grudziński, Bernardyni w stużbie ojczyzny, 114.
} 
i osób mieszkających w klasztorze, majątku ruchomego i nieruchomego, kapitałów i akt klasztornych. Pieniędzy w gotówce nie znaleziono. Wszystkie dokumenty klasztorne zebrano i złożono w celi gwardiana, pieczętując drzwi wejściowe. Wszystkie cele klasztorne zapieczętowano z wyjątkiem czternastu, które pozostawiono na mieszkanie dla zakonników pozostających w klasztorze, służby klasztornej i różnego rodzaju składy. Konie, rogaciznę i zboże zostawiono pod dozorem wikariuszów kościoła $\mathrm{z}$ zastrzeżeniem, że mogą tych rzeczy używać, ale nie sprzedawać. Nadzór nad majątkiem klasztornym przejął wójt gminy Skępe. Wikariuszom oddano naczynia i sprzęty liturgiczne, polecając odprawianie nabożeństw w kościele, a także utrzymanie szkoły klasztornej do czasu specjalnego rozporządzenia wyższych władz. Reszcie zakonników rozdano kożuchy i buty, a następnie na furmankach pod konwojem oddziału wojska wywieziono przez Dobrzyń i Płock do klasztoru w Warszawie, a następnie w Warcie. Znaleźli się wśród nich: gwardian Bonifacy Baryłkiewicz, Modest Bloch, Franciszek Garmuszkiewicz, Kazimierz Gęsty, Ludwik Jabłoński, Stanisław Kownacki, Grzegorz Kozłowski, Wincenty Lewandowski, Edward Lubowicki, Roch Michalski, Fortunat Nartowski, Adrian Nowak, Julian Petruszyński, Alfons Pilecki, Teodor Piotrowski, Sylwester Gajewski, Dydak Sobirajski, Witalis Żebrowski i Damazy Nałęcz. Do kasaty bernardyni prowadzili przy klasztorze szkołę elementarną. Biblioteka klasztorna w Skępem należała do lepiej zaopatrzonych w zakonnej prowincji wielkopolskiej. Po likwidacji klasztoru w 1864 r. większa część zbiorów bibliotecznych znalazła się w bibliotece seminarium duchownego w Płocku. Od 1868 r. w części klasztoru zamieszkał ksiądz diecezjalny Ferdynand Kroczewski i przejął parafię. Resztę klasztoru oddano władzom szkolnym ${ }^{71}$.

Upadek powstania styczniowego był równocześnie zmierzchem czterowiekowej działalności klasztoru bernardynów w Warcie. Wprawdzie nie zlikwidowano jeszcze całkowicie konwentu, ale ograniczono do minimum możliwości jego pracy i oddziaływania. Carskie władze uznały go za etatowy, do którego zwożono zakonników ze skasowanych klasztorów, wyznaczając im pewną kwotę pieniężną na utrzymanie. Już pod koniec listopada 1864 r. klasztor zaczął się wypełniać zakonnikami z Piotrkowa Trybunalskiego (30 listopada), ze Skępego i Przasnysza (2 grudnia). Ich liczba doszła do

${ }^{71}$ Michał Marian Grzybowski, „Duchowieństwo katolickie diecezji płockiej w okresie powstania styczniowego", Rocznik Towarzystwa Naukowego Plockiego (2013), 5: 38; Kalinowska, Bernardyni w Ostrołęce, 334; Wyczawski, Bernardyni, t. 3: 166; Wiesław Murawiec, „Skępe”, w: Klasztory bernardyńskie $w$ Polsce, 331, 332; Czesław Lissowski, Powstanie styczniowe $w$ ziemi dobrzyńskiej (Płock, 1938), 132-133, 135-139; Kantak, Bernardyni, t. 2: 545; APBK rkps XIII-10a, Kronika klasztoru oo. Bernardynów w Skępem, 3-10. 
osiemdziesięciu. Na skutek tego zapasy żywności, wystarczające dla kilkunastu stałych mieszkańców, wnet się wyczerpały. Trudności aprowizacyjne rozwiązał naczelnik wojenny $z$ Kalisza $w$ ten sposób, że wszystkich nowicjuszy, w liczbie osiemnastu, wydalił z klasztoru, dając każdemu 70 rubli na kupno cywilnego ubrania. Stan liczbowy topniał z każdym rokiem, ponieważ starzy zakonnicy umierali, a nowych kandydatów nie wolno było przyjmować. Ponadto niektórym młodszym kapłanom udało się wydostać z klasztoru na parafie do pracy duszpasterskiej. W 1868 r. zagęszczenie osób w klasztorze znowu wzrosło, ponieważ przywieziono tu zakonników ze skasowanego w tym czasie klasztoru w Strzegocinie koło Pułtuska. Władze zaborcze uważały klasztor etatowy za skasowany, dlatego też ingerowały w wewnętrzne jego sprawy przy każdej nadarzającej się sposobności. Przeprowadzały inwentaryzację majątku klasztornego i powodowały przeniesienia zakonników do innych miejsc koncentracji. Chodziło o to, aby stan personalny klasztoru etatowego spadł jak najprędzej poniżej ośmiu osób, bo wtedy konwent etatowy automatycznie ulegał likwidacji. Gdy w Warcie zanosiło się na zamknięcie klasztoru, gwardian Felicjan Szortyka zawczasu przekazał znajdujące się w Warcie archiwum prowincji wielkopolskiej do archiwum kapitulnego we Włocławku (zwrócono je zakonowi około 1950 r.). Należy tu wspomnieć, że gdy po kongresie wiedeńskim (1815) władze pruskie zaczęły systematycznie likwidować w swym zaborze klasztory, bernardyni przenieśli archiwum prowincji wielkopolskiej ze Wschowy na teren Kongresówki - do Warty. 26 lutego 1898 r. zjechała do Warty komisja mieszana, państwowo-kościelna, na której czele stał naczelnik powiatu sieradzkiego oraz wizytator klasztorów kurii biskupiej we Włocławku Stopieżyński z zamiarem wykonania rozkazu generał gubernatora warszawskiego odnośnie do zamknięcia klasztoru. Ponieważ budynek klasztorny był przewidziany na szpital dla umysłowo chorych, komisja po sporządzeniu inwentarza wydzieliła niedużą część gmachu od strony kościoła na mieszkanie dla przyszłego rektora kościoła i służby kościelnej, którym przyznano również część ogrodu klasztornego o powierzchni ponad 3 morgów. Ostatni bernardyni: gwardian Felicjan Szortyka, Franciszek Czachorowski i brat zakonny Filip Smoliński zostali przewiezieni do bernardyńskiego klasztoru etatowego w Kole. Po kasacie kościół przeszedł pod zarząd księdza diecezjalnego. Władze carskie położyły rękę na bogatym zbiorze bibliotecznym. Zostawiono do dyspozycji rektora kościoła tylko sto kilkadziesiąt książek. Pewną ich ilość przewieziono do Włocławka i znajdują się one do dziś w bibliotece seminarium duchownego ${ }^{72}$.

\footnotetext{
${ }^{72}$ Kajetan Grudziński, „Warta”, w: Klasztory bernardyńskie w Polsce, 424.
} 
Bernardyni w Widawie mieli pozytywny stosunek do powstania styczniowego. W śledztwie w sprawie mieszkającego tam Franciszka Sobalskiego stwierdzono, że pomimo braku osobistych zarzutów był podejrzany. Znaleziono u niego listy z Syberii, fotografie działaczy konspiracyjnych i książkę z wierszami patriotycznymi. Aleksandra Radzimińskiego i Damiana Śliwińskiego oskarżono po powstaniu o udział w manifestacjach przedstyczniowych i podburzające kazania. Gwardiana Marcelego Wójcika władze carskie pociągały do odpowiedzialności za patriotyczny nastrój w klasztorze i podburzające kazania. Mimo ogólnej kasaty w 1864 r. klasztor w Widawie został oszczędzony. Uczyniono z niego klasztor etatowy i zwożono do niego zakonników ze skasowanych konwentów. W takim charakterze klasztor w Widawie przetrwał do $1893 \mathrm{r}^{73}$

Również klasztory litewskie brały udział w powstaniu. W Cytowianach bernardyn Bazyli Dmochowski, na zlecenie Rządu Narodowego w Warszawie, ogłosił w niedzielę 24 marca 1863 r. w kościele klasztornym akt proklamacji powstania i uwłaszczenia chłopów. Z jego inicjatywy w czasie świąt wielkanocnych oblepiono mury kościoła odezwami Rządu Narodowego. W końcu Dmochowski poszedł do oddziału powstańczego jako kapelan, a cały ciężar odpowiedzialności wobec władz wziął na siebie gwardian klasztoru Andrzej Piotrowicz. Klasztor musiał spłacać nałożone grzywny za pięciu zakonników uznanych za aktywnych działaczy patriotycznych. Za każdego księdza zapłacono po 50 rubli, za trzech braci zakonnych po 25 rubli oraz za czterech kleryków po 15 rubli. W sumie gwardian zapłacił 335 rubli kary. Kary pieniężne jednak nie wystarczyły. Piotrowicz wraz z Jerzym Reichenbachem został skazany na zesłanie w głąb Rosji. Ten ostatni w 1873 r. mieszkał w Tunce na Syberii. Zakrystian, brat zakonny Paweł Łukaszewicz, został ukarany więzieniem za udostępnianie powstańcom paramentów liturgicznych. Uwięziono też dwóch księży: proboszcza Michała Mackiewicza i wikarego Szymona Janikowicza, bernardynów obsługujących kościół filialny w Szydłowie, za odczytanie z ambony manifestu Rządu Narodowego i współudział w powstaniu. Pod koniec września 1864 r. klasztor w Cytowianach został skasowany przez władze zaborcze. Wszystkich zakonników, oprócz tych, którzy wcześniej zostali uwięzieni, wywieziono do Rosień, stamtąd skierowano do klasztorów innych zakonów, które przez pewien czas miały jeszcze istnieć jako etatowe. Jedynie tylko Rufina Kimbara i brata zakonnego Ludwika Żylewicza umiesz-

\footnotetext{
${ }^{73}$ Wyczawski, Bernardyni, t. 3: 170; tenże, „Widawa”, w: Klasztory bernardyńskie w Polsce, 429.
} 
czono w bernardyńskim klasztorze etatowym w Kretyndze. Parafię przejęli księża diecezjalni, a w budynku klasztornym zamieszkał proboszcz ${ }^{74}$.

W Datnowie na Żmudzi bernardyni ogłosili w kościele klasztornym manifest Rządu Narodowego w Warszawie, wzywający do powstania, zachęcali do wstępowania $\mathrm{w}$ szeregi narodowe, udzielali powstańcom schronienia w klasztorze, wspierali ich materialnie. Aresztowano pięciu bernardynów zaangażowanych $\mathrm{w}$ szerzenie idei powstańczej i przyjmujących przysięgi od ochotników: gwardiana Ferdynanda Prokopowicza, proboszcza przyklasztornej parafii Wenantego Kowalewskiego, ojców Jerzego Rejchenbacha i Wincentego Kowalewskiego oraz brata zakonnego Leonarda Butkiewicza. Gwardian klasztoru oraz Wenanty Kowalewski i Wincenty Kowalewski zostali wywiezieni w głąb Rosji. W 1870 r. Prokopowicz zmarł na terenie guberni tomskiej, Wenanty Kowalewski zaś w 1877 r. przebywał w miejscowości Wałdaj w guberni wielkonowogrodzkiej. Rejchenbach przez kilka lat odbywał karę w Nerczyńskich Rudnikach w Akatui. Kasata klasztoru w Datnowie nastąpiła przy końcu września 1864 r. Znajdowało się tam wówczas jeszcze dziesięciu zakonników, nie licząc wcześniej aresztowanych. Wywieziono ich do klasztorów etatowych innych zakonów. Kościół i klasztor przejęli księża diecezjalni ${ }^{75}$.

Również klasztor bernardyński w Słonimiu, w diecezji wileńskiej, odegrał pewną rolę w ruchach wolnościowych XIX w., mianowicie w tzw. manifestacjach narodowych w latach 1861-1862 i w powstaniu styczniowym. W 1861 r. odbywały się w kościele bernardyńskim patriotyczne nabożeństwa, w czasie których wygłaszano nastrojone na nutę narodową kazania i śpiewano zakazane przez władze zaborcze pieśni. Za sympatię dla powstania styczniowego klasztor słonimski, na mocy zarządzenia gubernatora wileńskiego, zapłacił 308 rubli grzywny, a jeden z zakonników, o. Antoni Maciutowicz, przebywał przeszło rok w więzieniu. Kasata klasztoru w Słonimiu odbyła się 21 grudnia 1864 r. Znajdowało się wówczas w konwencie dwudziestu jeden zakonników, w tym szesnastu kapłanów i pięciu braci zakonnych. Z liczby tej pięciu kapłanów pracowało w duszpasterstwie parafialnym poza klasztorem, a mianowicie Protazy Dymanowicz jako mansjonarz przy kościele w Doni w powiecie wileńskim, Mateusz Stański przy kościele fi-

${ }^{74}$ Murawiec, Zaangażowanie patriotyczne zakonników franciszkańskich, 317; Kajetan Grudziński, „Cytowiany”, w: Klasztory bernardyńskie w Polsce, 44; Kubicki, Społeczna działalność Kościoła w Polsce, 186; APBK rkps I--1-12, Wykaz alfabetyczny, s. 10.

${ }^{75}$ Grudziński, Działalność patriotyczna, 119; tenże, „Datnów”, w: Klasztory bernardyńskie w Polsce, 46-47; Kubicki, Społeczna działalność Kościoła w Polsce,186; APBK rkps I-ł-12, Wykaz alfabetyczny, s. 6. 
lialnym w Kotnicy, należącej do parafii mereckiej, Modest Filipowicz przy kościele filialnym bogdanowskim w guberni wileńskiej, Benedykt Nakutowicz jako administrator parafii Dziewiątkowicze koło Słonimia. Wobec wyżej wymienionych władze carskie wydały orzeczenie, że mogą pozostać na swoich stanowiskach, dopóki władze kościelne nie przyślą na ich miejsce kapłanów diecezjalnych. Dwaj kapłani, spełniający posługę duszpasterską w kościele bernardynek w Słonimiu, którzy decyzją władz carskich stali się etatowymi dla sióstr z różnych klasztorów i zakonów, zostali na razie na miejscu i mogli wykonywać swoje dotychczasowe zajęcia. Byli to ojcowie Klodoald Chilkiewicz i Filip Tarasiewicz. Inni kapłani: Barnaba Błażkiewicz, Józef Soroko, Leon Rypiński, Serwant Bołtuć, Cyprian Jankiewicz, Romuald Łukaszewicz, Gabriel Bierzański, Feliks Gozdowski i bracia zakonni Ludwik Czajkowski, Odoryk Paszkiewicz, Tomasz Sorokiewicz, Serafin Galinowskł i Teofil Gregołowicz zostali pod strażą przewiezieni do etatowych klasztorów: dominikanów w Nieświeżu (8) i franciszkanów konwentualnych w Grodnie (7). Kościół klasztorny zamieniono w 1866 r. na filię prawosławnej cerkwi sobornej w Słonimiu. Budynki klasztorne oddano pod zarząd policji, a place i ogrody do dyspozycji Izby Dóbr Państwowych. Książki z biblioteki klasztornej o treści teologicznej, po ich przejrzeniu przez komisję państwową, zostały przekazane władzy kościelnej, inne, także rękopisy, wysłano do wileńskiej Centralnej Biblioteki Publicznej ${ }^{76}$.

Za najbardziej szkodliwe i nieprawomyślne w Wilnie uznano klasztory bernardynów i franciszkanów konwentualnych. Do najbardziej aktywnych bernardynów w czasie powstania należał Gabriel Bierzański, skazany na zesłanie w głąb Rosji. Po amnestii przebywał w 1876 r. w miejscowości Połąga na terenie Kurlandii. Do akcji powstańczej włączył się również kleryk bernardyński z wileńskiego konwentu Adrian Nowicki. Mobilizował on młodzież, przekazując ochotnikom pieniądze i ekwipunek, a następnie wysyłając ich do oddziału w Puszczy Białowieskiej. Na skutek donosów został osadzony w cytadeli wileńskiej, a następnie zesłany do guberni permskiej, gdzie w $1879 \mathrm{r}$. przebywał w miejscowości Kungur. Wileński bernardyn Romuald Łukaszewicz utrzymywał kontakty ze znanym przywódcą powstania na Litwie Konstantym Kalikowskim. Łukaszewicz został uwięziony za działalność powstańczą. Kasata klasztoru wileńskiego nastąpiła w 1864 r. Brata zakonnego Remigiusza Poskoczyna przewieziono do bernardyńskiego klasztoru w Mohylewie, który przez pewien czas był miejscem koncentracji zakonników. Innych zakonników przesiedlono między innymi do Kretyngi. Kościół oddano pod opiekę księżom

\footnotetext{
${ }^{76}$ Kajetan Grudziński, „Słonim”, w: Klasztory bernardyńskie w Polsce, 336.
} 
diecezjalnym, a klasztor przejęły władze cywilne. Trudno dociec, co się stało $\mathrm{z}$ bogatą biblioteką klasztorną liczącą w XIX w. około 7000 woluminów ${ }^{77}$.

Za udział zakonników w powstaniu styczniowym został skasowany na Litwie klasztor w Mohylewie, z którego zakonników przeniesiono do klasztorów w Kretyndze i Mińsku, oraz klasztor w Nieświeżu, z którego zakonników w większości przesiedlono do etatowego klasztoru w Kretyndze. W budynkach poklasztornych w Mohylewie w 1865 r. urządzono archiwum sądu, zaś w Nieświeżu w 1892 r. w kościele cerkiew prawosławną pod wezwaniem św. Jerzego, a w klasztorze koszary wojskowe ${ }^{78}$.

Klasztory bernardyńskie na Rusi także wspierały powstańców. Gdy wybuchło powstanie styczniowe w Królestwie Polskim, klasztor w Sokalu stał się placówką współpracującą z powstańcami jako punkt przerzutów ludzi i broni. Od maja do października 1863 r. istniał w klasztorze szpital dla rannych powstańców ${ }^{79}$.

Pomimo kasaty klasztoru bernardyńskiego w Budsławiu na Białorusi w 1858 r. kilku bernardynów pozostało w okolicy. W 1863 r. łączyli się z powstańcami. Jednemu z nich, Feliksowi Szukiewiczowi, udało się przedostać do Galicji w 1869 r. Zamieszkał w klasztorze w Kalwarii Zebrzydowskiej, gdzie zmarł w 1878 r. ${ }^{80}$

Nie tylko klasztory bernardynów, ale także i bernardynek były ostoją dla uczestników powstania styczniowego. Pomimo że w ruchach wolnościowych siostry nie brały bezpośredniego udziału, to jednak ich klasztory i kościoły były wykorzystywane do celów konspiracyjnych. Dlatego ukazem cara Aleksandra II z 8 listopada 1864 r. klasztor bernardynek w Lublinie został skasowany. Siostry przewieziono do klasztoru bernardynek w Łowiczu, natomiast kościół oddano pod opiekę rektora, wyznaczonego przez biskupa lubelskiego, który zajął część klasztoru, przylegającą do kościoła. Część klasztoru przeznaczono dla lokatorów, część wyburzono przy poszerzaniu ulicy, reszta, zdewastowana, stała pusta do 1919 r., kiedy to kościół i klasztor przejęli jezuici ${ }^{81}$.

${ }^{77}$ Murawiec, Zaangażowanie patriotyczne zakonników franciszkańskich, 316; Kajetan Grudziński, „Wilno”, w: Klasztory bernardyńskie w Polsce, 439; tenże, Działalność patriotyczna, 117; APBK rkps I-ł-12, Wykaz alfabetyczny, 2, 14.

${ }^{78}$ Gach, „Formy działalności Braci Mniejszych”, 295; Wiesław Murawiec, „Mohylew”, w: Klasztory bernardyńskie w Polsce, 226; tenże, „Nieśwież”, w: Klasztory bernardyńskie w Polsce, 233.

${ }^{79}$ Augustyn Chadam, „Sokal”, w: Klasztory bernardyńskie w Polsce, 349; Grudziński, Bernardyni w stużbie ojczyzny, 105.

${ }^{80}$ Wiesław Murawiec, „Budsław”, w: Klasztory bernardyńskie w Polsce, 34.

${ }^{81}$ Augustyn Chadam, „Konwenty bernardynek. Lublin”, w: Klasztory bernardyńskie w Polsce, 526. 
Oprócz wymienionych bernardyńskich klasztorów także inne na swój sposób wspierały powstańców, o czym pisał Kajetan Grudziński: „W klasztorach zbiegały się nici tajnych organizacji patriotycznych, które gęstą siecią opasały wówczas cały niemal kraj, nie tylko Królestwo, ale Litwę i Ruś, a nawet ziemie zaboru austriackiego. Niejednokrotnie wybitną rolę $\mathrm{w}$ tych organizacjach odgrywali bernardyni. Klasztory były ogniskami, gdzie skupiały się elementy najbardziej patriotyczne, nie tylko spośród zakonników, ale i ludzi świeckich. W bernardyńskich ustroniach sztab swój zakładali nieraz przywódcy powstania i kierownicy organizacji podziemnych. $\mathrm{Z}$ ambon bernardyńskich kościołów odczytywano akt proklamacji powstania i uwłaszczenia włościan, zachęcano do jak najliczniejszego wstępowania w szeregi narodowe, zagrzewano naród do walki zbrojnej o wolność ojczyzny. Świątynie bernardyńskie były świadkami przysiąg, które odbierali zakonnicy. Charakterystyczną jest rzeczą, że Artur Grottger, przekładając na płótno historyczny moment składania przysięgi na sztandary narodowe przez bohaterów styczniowego zrywu wolnościowego, umieścił tam bernardynów. Klasztory służyły powstańcom jako punkty oparcia, gdzie po trudach obozowego życia, nieraz ścigani przez wroga, znajdowali spoczynek, ciepłą strawę, odzież, pieniądze, słowo otuchy i zachęty. Niejednokrotnie w klasztorach mieściły się składy $\mathrm{z}$ bronią i umundurowaniem przeznaczonym dla powstania. Zakonnicy werbowali nowych ochotników do walki z wrogiem, a niekiedy sami zasilali oddziały powstańcze, nie tylko jako kapelani obozowi, by roztoczyć nad walczącymi pieczę duchową, ale również bardzo często jako prości żołnierze, by walczyć z bronią w ręku" 82 .

Działalności wielu bernardynów-powstańców, ściganych przez władze zaborcze, nie można powiązać z jakimkolwiek klasztorem, gdyż wędrowali z klasztoru do klasztoru, by uniknąć zesłania na Syberię. Wśród nich byli kleryk bez ślubów uroczystych Bartłomiej Rybus, kleryk Florian Ragiel i Bernard Bulsiewicz. Pierwszy z nich wystąpił z zakonu i poszedł do powstania, służąc $\mathrm{w}$ oddziałach $\mathrm{z}$ bronią w ręku. Bernardyni wszędzie przyjmowali go życzliwie i ukrywali w różnych klasztorach, między innymi w Czerniakowie, Skępem, Kaliszu i Górze Kalwarii. Na mocy uchwały kapituły prowincjalnej w Skępem 5 maja 1863 r. został on z powrotem przyjęty do zakonu, w końcu jednak został schwytany przez Rosjan i zesłany w głąb imperium ${ }^{83}$. Bulsiewicz brał czynny udział w powstaniu styczniowym od jego wybuchu

${ }^{82}$ Grudziński, Bernardyni w stużbie ojczyzny, 89.

${ }^{83}$ Wyczawski, Bernardyni, t. 3: 163; Murawiec, Bernardyni warszawscy, 185; Kantak, Bernardyni, t. 2: 545; APBK rkps RGP-k-62, Teki Cz. Bogdalskiego, t. 45, k. 242, 243. 
do upadku. Był wielokrotnie ranny. Historyk zakonny Czesław Bogdalski pisał o nim, że był ranny w różnych potyczkach aż osiemnaście razy, najciężej w bitwie pod Kobylanką. Po upadku powstania i po odprawieniu pokuty powrócił do zakonu, ale miał problemy w różnych diecezjach z uzyskaniem zezwolenia na odprawianie mszy, uważano bowiem, że naruszył prawo kanoniczne i popełnił grzechy zastrzeżone do rozgrzeszenia Stolicy Apostolskiej, zwrócił się więc do kongregacji rzymskiej i po kilku latach pokuty otrzymał zwolnienie z kar kościelnych. Mieszkał w dziewięciu różnych klasztorach na terenie Galicji. Najdłużej w Tarnowie, gdzie wydawał dwa pisma o charakterze politycznym Dzwonek i Pogoń, musiał jednak zrezygnować z działalności wydawniczej, gdyż władze konfiskowały poszczególne numery i nakładały wysokie grzywny. W końcu wyemigrował do Ameryki, gdzie do śmierci pracował wśród Polonii (zm. 1895) ${ }^{84}$.

Bernardyn Serafin Schultz (vel Szulc) w czasie powstania był kapelanem w oddziale Apolinarego Kurowskiego, a następnie Teodora Cieszkowskiego. Po rozbiciu oddziału uszedł do Galicji, gdzie był kolejno kapelanem w formujących się oddziałach Andrzeja Łopackiego i Dionizego Czachowskiego. Po klęsce tego ostatniego przeniósł się w okolice Piotrkowa Trybunalskiego, Sieradza i Wielunia, gdzie werbował chłopów do powstania, za co Rosjanie wyznaczyli nagrodę za jego głowę. Po upadku powstania wrócił na teren Galicji, a stamtąd udał się na emigrację ${ }^{85}$.

\section{PODSUMOWANIE}

Rząd rosyjski zastosował ostre represje nie tylko wobec oskarżonych zakonników z zsyłką na katorgę włącznie, ale również uderzył w same klasztory jako instytucje. 8 listopada (27 października starego stylu) 1864 r. cesarz Aleksander II wydał ukaz w Carskim Siole, mocą którego kasował w Królestwie Polskim 114 klasztorów (110 męskich, 4 żeńskie) z ogólnej ich liczby 197 wszystkich wówczas istniejących (155 męskich, 42 żeńskich). W bernardyńskiej prowincji wielkopolskiej zniósł 10 konwentów z 18 funkcjonu-

${ }^{84}$ Grudziński, Działalność patriotyczna, 124, 125; Kantak, Bernardyni, t. 2: 546; Józef Stanisław Pietrzak, Księża powstańcy 1863 (Kraków, 1916), 63; APBK rkps RGP-k-25, Teki Cz. Bogdalskiego, t. 25, k. 34.

${ }^{85}$ Przygodzki, Losy bernardynów kaliskich i klasztoru w okresie zaborów (1793-1914), 70; Wyczawski, Bernardyni, t. 3: 169-170; tenże, „Schultz”, w: Słownik polskich pisarzy franciszkańskich, 433-434; S. Schultz, „Pamiętnik kapelana”, w: Polska w walce. Zbiór wspomnień i pamiętników (Paryż, 1868), 67-143. 
jących. Skasowano wówczas klasztory w Czerniakowie, Kaliszu, Łęczycy, Ostrołęce, Piotrkowie Trybunalskim, Przasnyszu, Skępem, w Świętej Annie, Warszawie i Złoczewie. Zespoły zakonników w kasowanych klasztorach wówczas dość liczne, jak w Kaliszu - 18 zakonników, w Piotrkowie - 24, w Skępem - 16, w Warszawie - 21. W Czerniakowie, Ostrołęce, Piotrkowie Trybunalskim, Przasnyszu, Skępem, Świętej Annie, Warszawie pozostawiono po jednym kapłanie do obsługi kościoła, ale już w 1867 r. przybył do Piotrkowa Trybunalskiego ksiądz diecezjalny, w 1868 r. do Skępego i Świętej Anny, w 1869 r. do Czerniakowa, w 1875 r. do klasztoru warszawskiego, w 1889 r. do Ostrołęki. Usuniętych z klasztorów zakonników przewieziono do pozostałych klasztorów. W prowincji małopolskiej przeprowadzono kasatę klasztorów w tym samym czasie, co $\mathrm{w}$ prowincji wielkopolskiej i w innych zakonach, w nocy z 27 na 28 listopada 1864 r., na mocy ukazu Aleksandra II z 27 października 1864 r. Z 12 klasztorów bernardyńskiej prowincji małopolskiej 7 uległo kasacie: w Jeleńcu, Kazanowie, w Kielcach na Karczówce, Lublinie, Opatowie, Radomiu i Kobyłce. Z 5 pozostałych zniesiono 2 października 1865 r. klasztory w Józefowie, Krześlinie i w Łukowie. Klasztor w Radecznicy skasowano w 1869 r. na podstawie sugestii grekokatolickiego biskupa chełmskiego Michała Kuziemskiego, który usiłował stworzyć w Radecznicy religijny ośrodek grekokatolicki. Pozostał jedynie jako etatowy klasztor w Wielkowoli (Paradyżu). Zakonników ze skasowanych w 1864 r. klasztorów przeniesiono do konwentów pozostałych, a ze skasowanych w 1865 r. najwięcej do Wielkowoli, resztę do klasztorów etatowych prowincji wielkopolskiej. Kilku bernardynów zgłosiło się do pracy na parafiach lub na wyjazd za granicę, na co rząd chętnie się zgodził. Klasztor w Wielkowoli pomieścił wówczas trzydziestu zakonników. Przy opuszczonych kościołach klasztornych pozwolono pozostać po jednym kapłanie do ich obsługi w Karczówce, Lublinie, Opatowie, po dwóch w Józefowie i Radomiu. Inne kościoły objęli od razu księża diecezjalni, a niebawem i te, przy których pozostało po jednym lub po dwóch bernardynów. Losy klasztoru etatowego w Wielkowoli były podobne do położenia takich konwentów w prowincji wielkopolskiej. Został on we wszystkim uzależniony od Komisji Spraw Wewnętrznych i Duchownych, która swe decyzje odnośnie do tego klasztoru przesyłała za pośrednictwem biskupa sandomierskiego, a następnie z mandatu biskupa przez wizytatora klasztorów. W 1893 r. żyło w tym klasztorze już tylko dwóch ojców i dwóch braci. Nie chcąc nań dłużej łożyć, ponieważ klasztory etatowe pozostawały na etacie państwowym, zniesiono go 
w tym roku, a pozostałych czterech zakonników przeniesiono do klasztoru etatowego w Warcie. $\mathrm{W}$ ten sposób prowincja małopolska przestała istniec ${ }^{86}$.

Ogarniając jednym spojrzeniem podany tu przegląd wydarzeń politycznych w bernardyńskich klasztorach w Królestwie Polskim, łatwo zauważyć, że prawdopodobnie połowa zakonników była zaangażowana $\mathrm{w}$ działalność powstańczą. Uznać to trzeba za zryw szlachetny, jak stwierdził bernardyński historyk Hieronim Eugeniusz Wyczawski, będący wyrazem umiłowania ojczyzny i wolności. $Z$ drugiej strony nie sposób nie dostrzec, że w podejmowanych przez bernardynów akcjach brakowało rozwagi, umiejętności organizowania pracy konspiracyjnej, toteż nic dziwnego, że władze rosyjskie w prowadzonych po upadku powstania śledztwach policyjnych dowiadywały się łatwo wszystkiego o każdym prawie zakonniku, nie tylko o jego antyrosyjskich wystąpieniach, ale nawet o jego sympatiach dla ruchu powstańczego ${ }^{87}$. Władze poprzez kasaty rozbiły struktury bernardynów w Królestwie Polskim. Wielu zakonników zagubiło sens prowadzenia życia zakonnego, co przejawiało się w częstych prośbach o sekularyzację oraz emigracji. Była to cena, jaką bernardyni płacili za zaangażowanie patriotyczne i związanie swego życia z losami społeczeństwa polskiego. W klasztorach pozostało niewielu zakonników. Ich liczba pomniejszała się wskutek zgonów i zakazu przyjmowania nowych kandydatów. Brak delegata generalnego, rezygnacja prowincjałów lub definitorów z prób kierowania współbraćmi, choćby przez bycie ostoją moralną, wpływały na zakonników przygnębiająco. W tej sytuacji trudno mówić o jakiejkolwiek aktywności zewnętrznej.

Niniejszy artykuł oparłem na literaturze przedmiotu. Nie sięgałem zatem do źródeł dość obszernie wykorzystywanych przez innych badaczy. Podjąłem się jedynie pewnego scalenia dotychczasowych wyników ich badań. Prowadząc kwerendę w Archiwum Prowincji oo. Bernardynów w Krakowie napotkałem 18-stronicowy rękopis przedstawiający Wykaz alfabetyczny biskupów i kapłanów oraz zakonników polskich przebywajacych do obecnej chwili na wygnaniu w Syberii i głębokiej Rosji. Został on napisany przez nieznanego autora (może o. Norberta Golichowskiego) we Lwowie, w czerwcu 1881 r. Obrazuje losy duchowieństwa polskiego po powstaniu styczniowym. Nie spotkałem jednak, by któryś z badaczy wykorzystał go w swojej pracy naukowej. Postanowiłem zatem opublikować rękopis w aneksie.

\footnotetext{
${ }^{86}$ Prejs, „Bernardyni w Królestwie Polskim po kasacie 1864 r.”, 441-445; Wyczawski, Bernardyni, t. 3: 171, 191-192; Piotr Paweł Gach, Kasaty zakonów na ziemiach dawnej Rzeczypospolitej i Ślaska 1773-1914 (Lublin, 1984), 183.

${ }^{87}$ Wyczawski, Bernardyni, t. 3: 170-171.
} 


\title{
ANEKS
}

Źródło: APBK rkps I-ł-12, Wykaz alfabetyczny biskupów i kapłanów oraz zakonników polskich przebywających do obecnej chwili na wygnaniu w Syberii i głębokiej Rosji (1881), 1-18.

\author{
WYKAZ ALFABETYCZNY \\ BISKUPÓW I KAPŁANÓW ORAZ ZAKONNIKÓW POLSKICH \\ PRZEBYWAJĄCYCH DO OBECNEJ CHWILI \\ NA WYGNANIU W SYBERYI I GŁĘBOKIEJ ROSSYI
}

\section{BISKUPI}

1. Borowski Kacper, biskup łucko-żytomierski - Perm od r. 1870.

2. Feliński Szczęsny Zygmunt, arcybiskup warszawski - Jarosław nad Wołgą od r. 1863.

3. Krasiński Adam Stanisław, biskup wileński - Wiatka od r. 1863.

4. Rzewuski Paweł, nominat biskup sufragan warszawski - Astrachan od r. 1865 .

\section{KAPŁANI}

Data położona przy nazwisku oznacza rok, z którego pochodzi informacja o kapłanie, przebywającym na wygnaniu, potrzebna dlatego, że wygnańcy miejsca pobytu nieraz zmieniają i dzisiaj niejeden już tam nie mieszka, gdzie mieszkał przed kilku laty, a niejeden może już przeniósł się do wieczności albo do kraju powrócił, czego w każdym pojedynczym wypadku dla trudności w komunikacji i korespondencji sprawdzić niepodobna.

[s. 2] 1. Abratowski Edward z zakonu OO. Reformatów z Płocka - Cywilsk, gubernia kazańska, 1876.

2. Bajkowski Władysław wikary z Pezorowa, diec. wileńskiej - Symbirsk, 1881.

3. Bakiewicz Jerzy z Truskowa, diec. żmudzkiej - Tomsk na Syberyi, 1876.

4. Balcewicz Jan z archidiec. mohylewskiej - Samara, 1880.

5. Barabasz Walenty proboszcz ze Skrzyńska, diec. sandomirskiej - Perm, 1877.

6. Bartoszewicz Jozef wikary z Godlewu, diec. augustowskiej - Tomsk na Syberyi, 1876. 
7. Bartoszewicz Andrzej I Dominikanin, administrator z Malużyna, diec. płockiej - Schoenberg w Kurlandyi, 1877.

8. Bartoszewicz Andrzej II profesor seminarium w Mińsku - Gorodiszcze, gubernia penzeńska, 1880.

9. Bernardyn, ksiądz z Warszawy, niewiadomego nazwiska - Noworżew, gubernia pskowska, 1876.

10. Berżański Gabryel Bernardyn z Wilna - Połąga w Kurlandyi, 1876.

11. Brodnicki Anastazy proboszcz w Lachowcach, diec. łucko-żytomirskiej w Kurlandyi 1877.

12. Brondzo Antoni wikary z Barznik, diec. augustowskiej - Tiemników, gubernia tambowska, 1870 .

13. Broniszewski Ludwik administrator $\mathrm{z}$ Komarówki, diec. podlaskiej Perm, 1876.

14. Brudnicki Kajetan Karmelita z Lublina - Cywilsk, gubernia kazańska, 1878.

15. Brzostowicz Jan z Barbaryszek, diec. wileńskiej - Krasnoufimsk, gubernia permska, 1877.

16. Brzozowski Jan Pijar z Radziejowa, diec. kujawsko-kaliskiej - Kirsanów, gubernia tambowska, 1880 .

17. Bugień Benedykt $\mathrm{z}$ archidiec. mohylewskiej - Archangielsk, 1880 (wyjechał stamtąd nie widomo dokąd).

18. Bukowski Stanisław altarzysta z Nowego Płocka, diec. płockiej - Spask, gubernia tambowska, 1877.

19. Buterlewicz Jan z Rakowa, diec. mińskiej - Powieniec, gubernia ołoniecka, 1877.

20. Chodakiewicz Jan z Kozycina, diec. wileńskiej - Galicz, gubernia kostromska, 1880.

21. Chyliczkowski Jan proboszcz z Goraja, diec. lubelskiej - w okolicy Krasnojarska na Syberyi, 1877.

22. Ciągliński Izydor mansjonarz z Bodzentyna, diec. sandomierskiej - Spask, gubernia tambowska, 1880 .

23. Czarkowski Feliks wikary ze Zwiahla, diec. łucko-żytomirskiej Wołogda, 1880.

[s. 3] 24. Czarnecki Edmund z diec. łucko-żytomirskiej - Berczów na Syberyi, 1877. 
25. Czosnakiewicz Edward administrator z Goleszyna, diecezji płockiej Nowomoskowsk, gubernia jekaterynosławska, 1880.

26. Dawidowicz Józef rektor seminarium żmudzkiego - Iekaterynosław, 1880.

27. Dąbrowicz Leon z Niemirowa, diec. kamienieckiej - Niżny Nowogród, 1876.

28. Dąbrowski Stanisław gwardian OO. Kapucynów z Lublina - Subocz albo Kłukszta w Kurlandyi, 1880.

29. Delert Andrzej administrator z Bąkowa, archidiec. warszawskiej - Spask, gubernia tambowska, 1879 .

30. Demidowicz Jakób administrator z Wołożyna, diec. wileńskiej - Maryńska na Syberyi, 1876, później podobno w Kurlandyi.

31. Deszkleniewicz Ignacy z diecezji mińskiej - Tomsk na Syberyi, 1876.

32. Dobkiewicz Adam z diec. żmudzkiej - Schoenberg w Kurlandyi, 1877.

33. Dobrosielski proboszcz ze Słucka, diec. mińskiej - Wiatka, 1862.

34. Domański Paulin Bernardyn z Radomia - Usmań, gubernia tombowska, 1880.

35. Drewnowski Rafał Misjonarz z Warszawy - Tunka koło Irkucka na Syberyi, 1876.

36. Drzewiński Józef z diec. wileńskiej - Gołąga w Kurlandyi, 1876.

37. Dubowik Edward z diec. wileńskiej - Szenkursk, gubernia archangelska, 1881.

38. Dusejko Władysław wikary w Zwingiach, diec. żmudzkiej - w Kurlandyi, 1877.

39. Dyakiewicz Józef z Wołkowyska, diec. wileńskiej - Łowkiesa w Kurlandyi, 1877.

40. Dylewicz Leopold z Wiżnu, diec. wileńskiej - Carewokokszajsk, gubernia kazańska, 1881.

41. Dyszo Franciszek z archidiecezji mohylewskiej - Elerna w Kurlandyi, 1876.

42. Dziewulski Adam z diec. podlaskiej - Kłukszta w Kurlandyi, 1877.

43. Filipowicz Bolesław Kanonik regularny z Wilna - Cywilsk, gubernia kazańska, 1878.

44. Fiszer Michał proboszcz z Gołajewa, diec. kujawsko-kaliskiej - Perm, 1881.

45. Gabszewicz Andrzej profesor seminarium żmudzkiego - Gołtawa, 1876. 
46. Gajewski Edward wikary z Głębokiego koło Dzisny, diec. wileńskiej Kłukszta w Kurlandyi, 1880.

47. Gargilewicz Seweryn proboszcz z Zarąb Kościelnych, diec. płockiej Gorodiszcze, gubernia penzeńska, 1880.

[s. 4] 48. Gawełczyk Bonawentura Paulin z Częstochowy - Kiryłów, gubernia wieko-nowogrodzka, 1876.

49. Genutowicz Franciszek wikary katedry żmudzkiej - Biełoziersk, gubernia wielkowogrodzka, 1879.

50. Giegużyński Józef prezydent zgromadzenia XX. Marianów z Maryampola, diec. augustowskiej - Kłukszta w Kurlandyi, 1876.

51. Gieroczyński Andrzej proboszcz ze Zaskorek, archid. mohylewskiej Kursk, 1878.

52. Godlewski Celestyn z Wohynia diec. podlaskiej - Gorodiszcze, gubernia penzeńska, 1876.

53. Godlewski Leon Franciszkanin z Warszawy - w Usting, gubernia wołogodzka, 1880.

54. Grekowicz Michał z diec. mińskiej - Krasnonfimsk, gubernia permska, 1880.

55. Grocholski Feliks z archid. mohylewskiej - Psków, 1876.

56. Gromadzki Waleryan z diec. łucko-żytomierskiej - Tomsk na Syberyi, 1876.

57. Gryketys Bartłomiej profesor seminarium sejneńskiego - Spask, gubernia tambowska, 1881.

58. Grzymała Andrzej Reformat z Żuromina, diec. płockiej - Sardyń, gubernia kazańska, 1880.

59. Gucewicz Antoni proboszcz z Brwinowa, archid. warszawskiej Krasnonfimsk, gubernia permska, 1880.

60. Hrehorowicz Fortunat $\mathrm{z}$ diec. mińskiej - Szenkursk, gubernia archangelska, 1881.

61. Hrycewicz Kacper z archid. mohylewskiej - Direta w Kurlandyi, 1876.

62. Hryniewiecki Aleksander kapelan szkół w Trużanach, diec. wileńskiej Ryga, 1876.

63. Jabłonowski Walenty wikary z Brześcia Litewskiego, diec. wileńskiej Gorodiszcze, gubernia penzeńska, 1880.

64. Jacewicz Jan wikary z Owanty, diec. żmudzkiej - Ryga, 1876. 
65. Jackowski Stanisław profesor seminarium sandomierskiego - Pudoż, gubernia ołoniecka, (podobno w roku bieżącym powrócił do kraju).

66. Jakóbowicz Antoni proboszcz z Łodzi, archid. warszawskiej - w Mitawie w Kurlandyi, 1877.

67. Jakowicz Symeon filialista z Szawkot, diec. żmudzkiej - Gorodiszcze, gubernia penzeńska, 1880.

68. Jakubowski Antoni proboszcz z Serafinówki, diecezji mińskiej - Spask, gubernia tambowska, 1876 .

[s. 5] 69. Jankowski Aleksander wikary z Gowarczowa, diec. sandomierskiej Tunka, gubernia irkucka na Syberyi, 1876.

70. Jassewicz Onufry proboszcz z Ejragoły, diec. żmudzkiej - Spask, gubernia tambowska, 1881.

71. Jawszyc z Korycina, guberni grodzińskiej - Tobolsk na Syberyi, 1876.

72. Jaźwiec alias Jaźwiecki albo Iźwicki Juwenalin Kapucyn z Łomży, diec. augustowskiej - Archangelsk, 1881 (od lat 20 na wygnaniu).

73. John Józef proboszcz z Leniczyna, archid. warszawskiej - Nikołajewsk, gubernia samarska, 1880 .

74. Justynowicz Wincenty Trynitarz z Warszawy - Bebra w Kurlandyi, 1877.

75. Kalisty Andrzej wikary z Latowicza, archid. warszawskiej - Schoenberg w Kurlandyi, 1877.

76. Kamieniecki Władysław z Pierszaj, diec. mińskiej - Spask, gubernia tambowska, 1879.

77. Kamiński Franciszek Misjonarz z Warszawy - Subosz w Kurlandyi, 1877 (podobno umarl).

78. Kasperowicz Mikołaj, wikary z Trok, diec. wileńskiej - Perm, 1876.

79. Kasprzycki Mateusz wikary z Gowarczowa, diec. sandomierskiej - Tunka, gubernia irkucka na Syberyi, 1881.

80. Kawecki Antoni proboszcz z Horbaczewa, archid. mohylewskiej Biełoziersk, gubernia wielko-nowogrodzka, 1879.

81. Kiełpsz Julian wikary z Wobolnik, diec. żmudzkiej - w Kurlandyi, 1877, gdzie?

82. Kitowski Antoni z diec. wileńskiej - na Syberyi, 1876, gdzie?

83. Klimkiewicz Roch Bernardyn z Radomia - Cywilsk, gubernia kazańska, 1876. 
84. Klimowicz Ignacy Dominikanin z Warszawy - Spask, gubernia tambowska, 1881.

85. Kluczewski Erazm kapelan gimnazjum w Niemirowie, diec. kamienieckiej - Cywilsk, gubernia kazańska, 1877.

86. Knapiński Paweł proboszcz z Wiewca, diec. kujawsko-kaliskiej - Jarosław nad Wołgą, 1876.

87. Kochański Wincenty Dominikanin z diec. wileńskiej - Nowomoskowsk, gubernia iekaterynosławska, 1881.

88. Kolendo Adam wikary z diec. wileńskiej - Kłukszta w Kurlandyi, 1880.

[s. 6] 89. Komorowski Gwidon Bernardyn z Góry Kalwarii, diec. augustowskiej - Nowomoskowsk, gubernia jekaterynosławska, 1880.

90. Korecki Stanisław Reformat z Wielunia, diec. kujawsko-kaliskiej Carewokokszajsk, gubernia kazańska, 1881.

91. Korzeniewski Jan wikary z Białegostoku, diec. wileńskiej - Tobolsk w Syberyi, 1876.

92. Kosiński Franciszek proboszcz z Kamieńca Podolskiego, diec. kamienieckiej - Odessa, 1877.

93. Kossiłowski Jerzy z diec. żmudzkiej - Maryńsk, gubernia tomska w Syberyi, 1876.

94. Kowalewski Feliks proboszcz z Lutocina, diec. płockiej - Spask, gubernia tambowska, 1878.

95. Kowalewski Józef proboszcz z Wąsowa, diec. płockiej - W. Nowogród, 1876 (podobno wrócił do kraju).

96. Kowalewski Wenanty Bernardyn z Datnowa, diec. żmudzkiej - Wałdaj, gubernia wielkonowogrodzka, 1877.

97. Kozicki Dominik wikary z Łuknik, diec. żmudzkiej - Warnowicze w Kurlandyi, 1880.

98. Kozłowski Franciszek administrator z Niemoninn, diec. wileńskiej Demiańsk, gubernia wielkonowogrodzka, 1879.

99. Kozylewski czy Kasilewski Mateusz z diec. wileńskiej - Chołmogory, gubernia archangelska, 1876.

100. Krajewski Paweł podkustoszy katedralny z Janowa, diec. podlaskiej Galicz, gubernia kostromska, 1880.

101. Kruszyński Adam prałat katedry żytomirskiej, były administrator diecezji łucko-żytomirskiej - Rewal, 1881. 
102. Krzywicki - Penza, 1878.

103. Krzyżanowski Andrzej wikary z Faszczówki, diec. mohylewskiej - Smoleńsk, 1876.

104. Kuczewski Leonard proboszcz z Dynaburga, archid. mohylewskiej Chołmogory, gubernia archangelska, 1877.

105. Kulaszyński Mikołaj proboszcz z Łaszczowa, diec. lubelskiej - Spask, gubernia tambowska, 1881.

106. Lassota Bazyli Kapucyn z Lędu, diec. kujawsko-kaliskiej - Cywilsk, gubernia kazańska, 1879.

[s. 7] 107. Lenczewski Tomasz proboszcz z Kiwatycz, diec. wileńskiej - Tobolsk na Syberyi, 1876.

108. Leniewicz Jan wikary z Kurowa, diec. wileńskiej - Jadryń, gubernia kazańska, 1879.

109. Leszczyński Pijar z Chełma, diec. podlaskiej - Czyta za Bajkałem na Syberyi, 1876.

110. Lewczak Jacek Bernardyn z Radomia, diec. sandomierskiej - w guberni seratowskiej, 1877, gdzie?

111. Lewicki Kajetan wikary z Litynia, diec. kamienieckiej - Kamenka, gubernia saratowska, 1877.

112. Lipko Augustyn administrator z Rohotny, diec. wileńskiej - Mezeń, gubernia archangielska, 1881.

113. Lipnicki Augustyn kanonik katedralny wileński - Mitawa w Kurlandyi, 1879.

114. Lisiecki Feliks administrator z Domanowa, diec. wileńskiej - Kurmen koło Schoenberga w Kurlandyi, 1877.

115. Litwin, ksiądz niewiadomego nazwiska - mieszkał w 1876 w powiecie Wielkie Łuki, guberni pskowskiej.

116. Ludowicz Aleksander proboszcz z Uzdy, diec. mińskiej - Pudoż, gubernia ołoniecka, 1877.

117. Łapiński Szymon proboszcz z Adamowicz, diec. augustowskiej - Pudoż, gubernia ołoniecka, 1880.

118. Łappo Augustyn proboszcz z Horbaczewa, diec. mohylewskiej - Sławianosierbsk, gubernia jekaterynosławska, 1880.

119. Ławkowicz Józef administrator w Komajnach, diec. żmudzkiej - Tomsk na Syberyi, 1876. 
120. Łukaszewicz Ignacy z archidiec. mohylewskiej - Iekaterynosław, 1877.

121. Łukaszewicz Wincenty wikary z Powondenia, diec. żmudzkiej - Pudoż, gubernia ołoniecka, 1880.

122. Macewicz Maciej proboszcz z Linkowa, diec. żmudzkiej - Bansk w Kurlandyi, 1877.

123. Mackiewicz Adam z diec. żmudzkiej - Gorodiszcze, gubernia penzeńska, 1876.

124. Mackiewicz Aurelian proboszcz z Szereszewa, diec. wileńskiej - Tomsk na Syberyi, 1876.

125. Maczyński Piotr - Czerdyń, gubernia permska, 1879.

126. Malewicz Lucyan wikary z Krasnopola, diec. łucko-żytomirskiej Jekaterynosław, 1877.

127. Malewicz Wiktor z diec. mińskiej - Gorodiszcze, gubernia penzeńska, 1876.

128. Manelski Walenty proboszcz z Lubowidza, diec. płockiej - Spask, gubernia tambowska, 1876. 1876.

[s. 8] 129. Marcinowski Jan z diec. płockiej - Kołogryw, gubernia kostromska,

130. Markowski Filip Bernardyn z Warszawy - Nowomoskowsk, gubernia jekaterynosławska, 1880.

131. Martyszewski Franciszek z Nacun, diec. żmudzkiej - Jakobsztad w Kurlandyi, 1877.

132. Mędrkiewicz Firmin Reformat z Warszawy - Gorodiszcze, gubernia penzeńska, 1880.

133. Michalski Grzegorz Reformat z Pilicy, diec. kieleckiej - gubernia saratowska, 1877, gdzie?

134. Mienicki Ludwik administrator z Kobylnika, diec. wileńskiej - Kłukszta, 1877.

135. Mikutowicz Seweryn wikary z Kurżeńca, diec. wileńskiej - Łankiesa w Kurlandyi, 1877.

136. Milewski Aleksander z diec. żmudzkiej - Alschwang w Kurlandyi, 1877.

137. Minczewski Józef administrator z Krzemienicy, diec. wileńskiej Kłukszta w Kurlandyi, 1877.

138. Misiński Maryan gwardian OO. Bernardynów z Warszawy - Czerdyń, gubernia permska, 1879 . 
139. Moczulski Franciszek wikary z Niemokszt, diec. żmudzkiej - Bansk w Kurlandyi, 1877.

140. Mokrzycki Floryan Dominikanin z Litwy - W. Nowogród, 1879.

141. Moniuszko Aleksander kapelan w Horyhorkach, archidiecezji mohylewskiej - Tomsk na Syberyi, 1876.

142. Montwid Ludwik administrator z Poniewieża, diec. żmudzkiej - Mitawa w Kurlandyi, 1877.

143. Mościcki Wiktor wikary katedry płockiej - Czerdyń, gubernia permska, 1876.

144. Naraziński Ignacy proboszcz z Kleczewa, diec. kujawsko-kaliskiej Warnawin, gubernia kostromska, 1876.

145. Narwojsz Wincenty z diec. żmudzkiej - Jadryń, gubernia kazańska, 1877.

146. Nienałtowski Eugeniusz Kapucyn z Lędu, diec. kujawsko-kaliskiej Carewokokszajsk, gubernia kazańska, 1876.

147. Nowicki Feliks Bernardyn z diec. mińskiej - Felidberg koło Alschwangu w Kurlandyi, 1880.

148. Nowicki Grzegorz wikary z Dziewałtowa, diec. żmudzkiej - w Kurlandyi, 1877.

149. Olechnowicz Michał Kanonik regularny z Saryi, archidiec. mohylewskiej - Tomsk na Syberyi, 1876 (podobno wrócił do kraju).

[s. 9] 150. Ołtarzewski Emilian gwardian OO. Kapucynów z Lędu, diec. kujawsko-kaliskiej - Cywilsk, gubernia kazańska, 1877.

151. Onoszko Gabryel kanonik katedralny saratowski - Iekaterynosław, 1877.

152. Osiński Wincenty proboszcz z Sokół, diec. augustowskiej - Spask, gubernia tambowska, 1876.

153. Osmólski Wacław administrator $\mathrm{z}$ Włodzimierza, diecezji łuckożytomirskiej - w guberni kostromskiej, 1877, gdzie?

154. Ostapowicz Jan z diec. kamienieckiej - Odessa, 1877.

155. Owsiany Józef proboszcz z Oswieji, archidiec. mohylewskiej - Ryga, 1877.

156. Pacewicz Jan proboszcz z Użpola, diec. żmudzkiej - Czerepowiec, gubernia wielkonowogorodska, 1879.

157. Parafiński Kazimierz proboszcz z Czerska, archidiec. warszawskiej Obojany, gubernia kurska, 1878. 
158. Pieślak Konstanty z diec. żmudzkiej - Biełoziersk, gubernia wielkonowogrodzka, 1879.

159. Piotrowicz Antoni z Dusiat, diec. żmudzkiej - Subocz w Kurlandyi, 1877.

160. Piotrowicz Stanisław dziekan wileński - Powieniec, gubernia ołoniecka, 1877.

161. Piotrewski Onufry proboszcz z Opalina, diec. łucko-żytomirskiej - Usmuń, gubernia tambowska, 1876 .

162. Pisanko Józef wikary z Berezyny, diec. mińskiej - Cywilsk, gubernia kazańska, 1878.

163. Piwarski Konstanty proboszcz zgromadzenia XX. Filipinów w Studziannej, diec. sandomierskiej - Spask, gubernia tambowska, 1878.

164. Pliszczyński Alfons Dominikanin z Lublina - Jadryń, gubernia kazańska, 1878.

165. Pluro Benedykt z archidiec. mohylewskiej - Lievenbersen w Kurlandyi, 1876.

166. Pomiechowski Jan proboszcz z Dobrzejewic, diec. płockiej - Spask, gubernia tambowska, 1880 .

167. Pomirski Stanisław wikary z Płońska, diec. płockiej - Sławianosierbsk, gubernia jekaterynosławska, 1881.

168. Puchalski Jan proboszcz i dziekan nowogrodzki, prałat kapituły mińskiej - Jekaterynosław, 1879.

[s. 10] 169. Radziszewski Antoni administrator z Malina, diec. łucko-żytomirskiej - Taganrog, 1876.

170. Rajuniec Józef wikary z Brasławia, diec. żmudzkiej - Solikomsk, gubernia permska, 1876.

171. Rączewski, kapłan unita z Litwy, zesłany za Mikołaja I - Tagaj, gubernia symbirska, 1880.

172. Reichenbach Jerzy Bernardyn z Datnowa, diec. żmudzkiej - Gorodiszcze, gubernia penzeńska, 1877.

173. Renner Kacper wikary ze Szreńska, diec. płockiej - Jadryń, gubernia kazańska, 1881.

174. Rogoziński Franciszek administrator z Opinogóry, diec. płockiej - Libawa w Kurlandyi, 1877.

175. Rogoziński Teodor proboszcz z Tuliszkowa, diec. kujawsko-kaliskiej Galicz, gubernia kostromska, 1880. 
176. Romanowski z diec. wileńskiej - Omsk na Syberyi, 1877.

177. Rostkowski Jan wikary z Krasnegostawu, diec. lubelskiej - koło Kańska na Syberyi, 1876, gdzie?

178. Rozga Józef wikary ze Srednik, diec. żmudzkiej - Irkuck na Syberyi, 1876.

179. Rozwadowski Józef z Janowa, diec. podlaskiej - Gorodiszcze, gubernia penzeńska, 1879.

180. Rozwodowski Jan wikary z Malat, diec. wileńskiej - Maryńsk, gubernia tomska na Syberyi, 1876.

181. Rudzki Szczepan wikary z Poswola, diec. żmudzkiej - Tunka na Syberyi, koło Irkucka, 1876.

182. Rukujża Karol z Konwaliszek, diec. wileńskiej - Kańsk na Syberyi, 1876.

183. Sarnicki Dominik Karmelita, administrator z Machnówki, diec. łucko-żytomirskiej - gubernia archangielska, 1877 (umarł podobno w guberni charkowskiej).

184. Sękowski Tomasz regens seminarium w Sejnach, diec. augustowskiej Łowkiesa w Kurlandyi, 1877.

185. Serwiński Mateusz proboszcz z Kazimierza, diec. lubelskiej - Kostroma, 1881.

186. Sidorowicz Franciszek wikary z Białegostoku, diec. wileńskiej - W. Nowogrod, 1876.

187. Siekierzyński Józef wikary ze Słomczyna, diec. warszawskiej - Tunka, gubernia irkucka, 1877.

[s. 11] 188. Siesicki Justyn wikary z Zydyków, diec. żmudzkiej - Tunka, gubernia irkucka na Syberyi, 1876.

189. Skibniewski Kazimierz wikary z Kampinosa, archidiec. warszawskiej Tomsk na Syberyi, 1876.

190. Skirmont Cypryan proboszcz z Hanuszyszek, diec. wileńskiej - 1876, podobno w guberni astrachańskiej, gdzie?

191. Skorupski Michał administrator z Nowa Aleksandrowska, diec. żmudzkiej - Elerna w Kurlandyi, 1877.

192. Skulski Stanisław profesor seminarium w Kielcach - Direta w Kurlandyi, 1877 (miał się podobno udać do Windawy w Kurlandyi).

193. Smilgiewicz Ignacy wikary z Gonater, diec. żmudzkiej - Połąga w Kurlandyi, 1880.

194. Sobolewski Kazimierz administrator z Rozważowa, diec. łucko-żytomirskiej - Cywilsk, gubernia kazańska, 1877. 
195. Sredziński Józef proboszcz z Pierlejewa, diec. wileńskiej - Jekaterynosław, 1877.

196. Srowgiewicz Antoni kapelan szkół z archidiecezji mohylewskiej Jakobsztadt w Kurlandyi, 1877.

197. Stefanowicz Konstanty wikary z Trokieli, diec. wileńskiej - Tomsk na Syberyi, 1876.

198. Stefanowski Władysław wikary z diec. augustowskiej - Kazań, 1876.

199. Strowp Franciszek z diec. żmudzkiej - Szenkursk, gubernia archangielska, 1881.

200. Stulgiński Ferdynand proboszcz i dziekan z Onikszt, diec. żmudzkiej Mitawa w Kurlandyi, 1877.

201. Światłowski Teofil wikary z Kutna, archidiec. warszawskiej - Krasnonfimsk, gubernia permska, 1881.

202. Święcki Michał ze zgromadzenia XX. Marianów z diec. augustowskiejTobolsk na Syberyi, 1878.

203. Swolkien Mikołaj ze zgromadzenia XX. Augustianów w Kownie, diec. żmudzkiej - Łowkiesa w Kurlandyi, 1877.

204. Syrwid Onufry proboszcz z Wasiliszek, diec. wileńskiej - Spask gubernia tambowska, 1880.

[s. 12] 205. Szacki Grzegorz proboszcz z Zasławia, diec. łucko-żytomirskiej Psków, 1876.

206. Szarkowski Józef kapelan szkół z Telsz, diec. żmudzkiej - Połąga w Kurlandyi, 1877.

207. Szarkowski Placyd z diec. żmudzkiej - Połąga w Kurlandyi, 1877.

208. Szczepański Józef proboszcz z Rogowa, diec. sandomierskiej - Spask, gubernia tambowska, 1881 .

209. Szepietowski Aleksander administrator z Głonki, diec. augustowskiej Nowomoskowsk, gubernia jekaterynosławska, 1879.

210. Szpakiewicz Jan z diec. kieleckiej - Rownoje, gubernia saratowska, 1877.

211. Szukanowski Norbert wikary z Trok, diec. wileńskiej - Sławianosierbsk, gubernia jekaterynosławska, 1881.

212. Szymański Ignacy kapelan szkół z Radomia - Jadryń, gubernia kazańska, 1877.

213. Tabeński Mieczysław wikary od kościoła św. Jana w Wilnie - Połąga w Kurlandyi, 1876. 
214. Toczyski Piotr proboszcz z kotelni, diec. łucko-żytomierskiej - Niżny Nowogród, 1877.

215. Tomaszewicz Wincenty proboszcz z diec. wileńskiej - Bansk w Kurlandyi, 1877.

216. Tomaszewski Rafał Reformat ze Stobnicy, diec. kieleckiej - Penza, 1878.

217. Trzeciak Dominik z diec. żmudzkiej - Kłukszta w Kurlandyi, 1877.

218. Trzciński z diec. płockiej - Szenkursk, gubernia archangelska, 1876.

219. Tuszewski Józef wikary z Ćmielowa, diec. sandomierskiej - w okolicy Krasnojarska na Syberyi, 1876.

220. Tydyński Aleksander z diec. wileńskiej - Pinega, gubernia archangelska, 1876.

221. Uliński Wincenty administrator w Popielach, diec. żmudzkiej - Subocz w Kurlandyi, 1877.

222. Urbanowicz z diec. żmudzkiej - Kurlandya, 1877, gdzie?

223. Walentynowicz Jan filialista z Dębowa, diec. żmudzkiej - Wałdaj, gubernia wielkonowogrodzka, 1881.

224. Waszkiewicz Leon proboszcz i dziekan z Sumiliszek, diec. wileńskiej Gorodiszcze, gubernia penzeńska, 1876.

225. Wejt Mateusz z diec. żmudzkiej - Schoenberg w Kurlandyi, 1877.

226. Wierzbicki Antoni wikary z Dorsuniszek, diec. wileńskiej - Czergrowiec, gubernia wielkonowogrodzka, 1879.

[s. 13] 227. Wirszyłło Antoni z diec. żmudzkiej - Warnowicze w Kurlandyi, 1877.

228. Wirszyłło Jan z diec. wileńskiej - Schoenberg w Kurlandyi, 1877.

229. Witkiewicz Jan wikary ze Skirstymonia, diec. żmudzkiej - w Kurlandyi, 1877.

230. Witkowski Jan administrator z Dołubowa, diec. wileńskiej - Tomsk na Syberyi, 1876.

231. Włocki Fryderyk wikary ze Zwolenia, diec. sandomierskiej - Wierchotursk, gubernia permska, 1877.

232. Wojczulański Stanisław wikary z Chodla, diec. lubelskiej - w Usting, gubernia wołogodzka, 1880.

233. Wojnicz czy Wojniusz Feliks Franciszkanin z diec. wileńskiej - Kłukszta w Kurlandyi, 1877. 
234. Wojczyński Teofil regens płockiego konsystorza - Sigontino koło Buja, gubernia kostromska, 1877.

235. Wojsznar Augustyn proboszcz z Wisztyńca, diec. augustowskiej - Tomsk na Syberyi, 1876.

236. Worotyński Józef z archidiec. mohylewskiej - Ryga, 1879.

237. Woźniakowski Ludwik wikary z Radomia, diec. sandomierskiej w Usting, gubernia wołogodzka, 1880.

238. Wróblewski Antoni kanonik katedralny mohylewski, profesor akademii duchownej w Petersburgu - Gorodiszcze, gubernia penzeńska, 1880.

239. Wróblewski Konstanty z diec. żmudzkiej - Rubin w Kurlandyi, 1877.

240. Wydżga Mikołaj z diec. podlaskiej - Schoenberg w Kurlandyi, 1877.

241. Zacharczyk Mirosław proboszcz i dziekan w Wyszeniczach, diec. łucko-żytomirskiej - Charków, 1876.

242. Zagórski Józef proboszcz w Guniach, diec. wileńskiej - Gorodiszcze, gubernia penzeńska, 1878.

243. Zajtz Ludwik profesor seminarium w Kielcach - Ryga, 1877.

244. Zakrzewski Wojciech proboszcz z Lisowa, diec. sandomierskiej - Schoenberg w Kurlandyi, 1877.

245. Zambrzycki Józef z Rzepek, diec. augustowskiej - Jadryń, gubernia kazańska, 1880 .

246. Zarębski Zefiryn prowincjał OO. Bernardynów z Warszawy - Czerdyń, gubernia permska, 1879.

[s. 14] 247. Zatkalik Antoni unita żonaty i mający rodzinę, proboszcz Horodyszcza, diec. chełmskiej - Czerń, gubernia tulska, 1881.

248. Zgodziński Leopold wikary z Krasnegostawu, diec. lubelskiej - Kłukszta w Kurlandyi, 1877.

249. Zunkiewicz Anatol Reformat z Przasnysza, diec. płockiej - Cywilsk czy Jadryń, gubernia kazańska, 1880.

250. Znosko Andrzej wikary od św. Jana w Wilnie - Pinega, gubernia archangelska, 1881 .

251. Zygadłowski z diec. wileńskiej - Gorodiszcze, gubernia penzańska, 1876.

252. Żmijewski Józef proboszcz ze Złakowa, archid. warszawskiej - Odessa, 1876.

253. Żmudzin, ksiądz niewiadomego nazwiska - Warnawin, gubernia kostromska, 1876. 
254. Żuk Dominik proboszcz ze Skopiszek, diec. żmudzkiej - Kostroma, 1881.

255. Żuk Józef proboszcz z Wiszniewa, diec. wileńskiej - Dweta w Kurlandyi, 1877.

256. Żukowski Szymon proboszcz z Gieguzyna diec. wileńskiej - Ryga, 1877.

257. Żyłowicz Aleksander z diec. łucko-żytomirskiej - Nowoaleksandrowsk, gubernia jekaterynosławska, 1878.

\section{KLERYCY ZAKONNI}

1. Drozdys Wawrzyniec subdiakon zgromadzenia OO. Karmelitów w Warszawie - Carewokokszajsk, gubernia kazańska, 1880.

2. Garbowski Eliasz kleryk zgromadzenia OO. Karmelitów z Warszawy Wierchotursk, gubernia permska, 1876.

3. Kułakowski Feliks diakon zgromadzenia XX. Kamedułów z Bielan pod Warszawą - Carewokoszajsk, gubernia kazańska, 1881.

4. Nowicki Adryan diakon zgromadzenia OO. Bernardynów w Wilnie Kungur, gubernia permska, 1879.

5. Pałejkis Michał nowicjusz zgromadzenia OO. Karmelitów w Warszawie w Usting, gubernia wołogodzka, 1876.

6. Pichelski Józef, nowicjusz zgromadzenia XX. Reformatów w Warszawie Galicz, gubernia kostromska, 1876.

[s. 15] 7. Rojewski Michał kleryk zgromadzenia XX. Augustianów z Ciechanowa, dyec. płockiej - gubernia jekaterynosławska 1876, gdzie?

8. Skalski Cyryl kleryk zgromadzenia OO. Bernardynów z Przasnysza, diec. płockiej - w Usting, gubernia wołgodzka, 1876.

9. Sosnowski Anioł kleryk profes zgromadzenia OO. Dominikanów w Warszawie - Spask, gubernia tambowska, 1881.

\section{BRACISZKOWIE ZAKONNI}

1. Chodkiewicz Karol braciszek zgromadzenia OO. Kapucynów w Lędzie, diec. kujawsko-kaliskiej - Irkuck na Syberyi, 1881.

2. Fijałkowski Aleksy braciszek kapucyński z Lędu, diec. kujawsko-kaliskiej Irkuck na Syberyi, 1876.

3. Perzeński Konrad tercjarz zgromadzenia OO. Kapucynów w Lędzie, diec. kujawsko-kaliskiej - Carewokokszajsk, gubernia kazańska, 1876. 


\section{UWAGI}

[s. 16] 1. Oprócz kapłanów wyżej wymienionych, trzymanych na wygnaniu w Syberyi i Rossyi, są jeszcze inni internowani w kraju, w klasztorach, mający zabroniony wyjazd z miejscowości, w których przemieszkują. Do takich należą:

Zgierski Franciszek, proboszcz z Latyczowa,

Zmigrodzki Piotr, profesor seminarium żytomirskiego, obaj internowani w klasztorze OO. Kapucynów w Winnicy, guberni podolskiej.

Sowiński Albert, wikariusz katedry żytomirskiej internowany w klasztorze OO. Kapucynów w Starym Konstantynowie, guberni wołyńskiej.

Scisławski Jan proboszcz z Morachwy, internowany w klasztorze OO. Bernardynów w Zasławiu, guberni wołyńskiej.

Zapewne więcej jest takich kapłanów, odsuniętych od sprawowanych obowiązków, wyzutych $\mathrm{z}$ dochodów i skazanych na przymusowe zamieszkiwanie w wyznaczonych im miejscach.

2. Do tej kategorii policzyć należy także tych kapłanów, którym pozwolono z wygnania powrócić do kraju, ale zabroniono wszelkiego jawnego sprawowania funkcji kapłańskich. Do takich należą np. zamieszkali w Warszawie kapłani: Ludwik Czajewicz z archidiecezji warszawskiej, Ludwik Lebiedziński z diecezji wileńskiej. Będzie takich księży zapewne więcej jeszcze.

3. Spis powyższy nie ma pretensji do dokładności. Robiony we Lwowie na podstawie korespondencji nadchodzących od księży z wygnania, nie może być ani zupełnym, ani wolnym od błędów, trudno bowiem pozbierać wiadomości szczegółowe i pewne o tylu set kapłanach, rozproszonych na ogromnej przestrzeni imperium rosyjskiego. Chcąc mieć wykaz całkiem dokładny należałoby się chyba udać do wszystkich biskupów katolickich pod berłem rosyjskim, a osobliwie do metropolity mohylewskiego, w obrębie diecezji którego większa część wygnańców przebywa.

4. Pominięci zostali w spisie powyższym:

a) ci wszyscy, o których pewna jest wiadomość, że albo życie zakończyli na wygnaniu, albo do kraju powrócili, albo za paszportem emigracyjnym za granicę państwa rosyjskiego wyjechali.

b) Kapłani obrządku greckokatolickiego diecezji chełmskiej, którzy są internowani po różnych miejscach Królestwa Polskiego. Dokładny ich spis, pomieszczony w najnowszym dziele x. Prałata Likowskiego, nie doznał zmiany, oprócz kilku kapłanów, którzy albo pomarli albo do Galicyi wyjechali.

5. Na osobną wzmiankę zasługują kapłani wygnańcy, zamieszkali w Kurlandyi [s. 17] w liczbie około 70. Kiedy skutkiem manifestu carskiego z r. 1874 oswo- 
bodzono wielką część kapłanów zesłanych do Syberyi lub dalszych guberni rosyjskich, dano im paszporta dozwalające im mieszkać w całym Imperium Rosyjskiem, z wyjątkiem Królestwa Polskiego, zachodniego kraju, czyli prowincji zabranych i guberni: petersburskiej i moskiewskiej. Wówczas kto tylko mógł z kapłanów, szczególnie Żmudzini i Litwini, spieszyli do Kurlandyi, jako guberni najbliższej kraju, gdzie nadto można było znaleźć pomieszczenie i zajęcie przy katolickich parafialnych kościołach. Lecz rząd rosyjski prędko pomiarkował się, że za wielką łaskę wyświadczył wygnańcom, więc potem zabroniono dalszego udawania się do Kurlandyi. Ci, którzy zdążyli tam się umieścić pozostali już, ale im równie jak innym wygnańcom, do polskich dawnych prowincji powracać nie wolno. Połąga na Żmudzi niegdyś, obecnie przyłączona jest administracyjnie do Kurlandyi i dlatego i tam wygnańcy się znajdują.

6. Kilku wygnańców otrzymało posady wikariuszy przy kościołach katolickich w Rosyi lub Syberyi, ale i tym do kraju wracać nie wolno, więc zawsze się oni liczą do kategorii wygnańczej.

7. Kapłani będący na wygnaniu nie pobierają od rządu albo żadnego wsparcia albo tak szczupłe, że wyżyć z niego nie mogą i gdyby nie Msze św., które potajemnie odprawiają za stipendia otrzymywane $\mathrm{z}$ kraju, to niejeden by $\mathrm{z}$ głodu umrzeć musiał, zwłaszcza że wzbroniony im jest wszelki zarobek poboczny, stanowi kapłańskiemu odpowiedni, np. dawania lekcji. Stąd też wszyscy co prywatnego majątku nie posiadają, cierpią dotkliwy niedostatek.

8. Kapłani chociaż już niby to uwolnieni spod nadzoru policji, poza obręb miejscowości, w których są internowani, wydalać się nie mogą i na różne dokuczliwości ze strony władz są narażeni. Wielu chcąc się uwolnić od tego nieznośnego stanu, podawało prośbę o paszport emigracyjny za granicę, bez powrotu do Rossyi, ale ledwo kilku za szczególną protekcją taki paszport wydano, innym odmówiono, choć swoją prośbę kilkakrotnie ponawiali i chociaż już kilkanaście lat na wygnaniu przepędzili, a wiekiem podeszłym są przyciśnieni.

9. Zwraca się uwagę, że kapłanów co do natury ich mniemanych przestępstw, które ich na wygnanie przywiodły, na 3 główne kategorie podzielić należy:

a) na takich co wywiezieni zostali bez wyroku, drogą administracyjną za udział w manifestacjach r. 1861, które lubo natury politycznej ze zbrojnym powstaniem 1863 r. bezpośredniego związku nie miały. Kara zaś za nie wymierzona nie jest w żadnej proporcji do winy. Tak np. ks. Juwenalis Kapucyn za kazanie powiedziane w r. 1861 od dwudziestu lat bez przerwy na wygnaniu się znajduje.

b) na takich co obwinieni byli o udział w powstaniu $1863 \mathrm{r}$. i skazani zostali wyrokami sądów wojennych do ciężkich robót albo na deportacją na Syberyi, ze 
Syberyi zaś [s. 18] na mocy manifestu carskiego przeniesieni zostali do Rossyi europejskiej. W ciężkich robotach dzisiaj o ile wiadomo nie ma nikogo z kapłanów.

c) na takich co wywiezieni zostali za sprawy natury czysto kościelnej, nie mając żadnego związku z polityką, jak np. XX. Biskupi, szczególnie ks. biskup Borowski, ks. prałat Kruszyński z Żytomierza, ks. dziekan Piotrowicz z Wilna, który rytuał moskiewski spalił na ambonie, xx. Narwojsz i Szukanowski, wywiezieni za nie przyjęcie takiegoż rytuału, xx. Romanowski, Mozniakowski i Jackowski za rozszerzanie nabożeństwa do Najświętszego Serca Jezusowego, ks. Puchalski, ks. Butertewicz i ks. Ludowicz za opór przeciw Senczykowskiemu, ks. Wróblewski za to, że przestrzegł alumnów akademii duchownej petersburskiej, iż mający ich święcić biskup Staniewski jest w cenzurach kościelnych, ks. Znosko za odczytanie manifestu wojennego w r. $1877 \mathrm{w}$ polskiej parafii po polsku a nie po rosyjsku itd.

10. Jeżeli rząd rosyjski zdecyduje się uwolnić kapłanów z wygnania, konieczną jest rzeczą, ażeby im zapewnił fundusze na drogę, inaczej bowiem bardzo wielu dla ubóstwa, w którem się znajdują, nie będą mogli opłacić dalekiej drogi do kraju, a przez to albo całkiem nie będą mogli korzystać $\mathrm{z}$ amnestii, albo bardzo późno, zanim potrzebne fundusze uda im się zebrać. W razie jeżeli rząd rosyjski przystanie na odesłanie własnym kosztem kapłanów do ich diecezji, niech to będzie tak zwanym porządkiem etapnym, zastosowanym do pospolitych, kryminalnych przestępców, których pędzą od stacji do stacji pieszo, a na noc zamykają do aresztu policyjnego razem ze zbrodniarzami. Taką bolesną drogę odbywało wielu z kapłanów, gdy uwolnieni z Syberyi nie mieli za co jechać na własny koszt do Rossyi. Odstawieni tedy zostali wyżej opisanym sposobem. Jeżeli tera nastąpi amnestia, należy zastrzec, aby kapłanom powrót przyzwoity i ludzki na koszt rządu był zabezpieczony.

11. Oprócz kapłanów są na wygnaniu osobliwie w guberni chersońskiej setki chłopów unitów z Podlasia, cierpiących za wierność wierze Świętej Katolickiej.

Czerwiec 1881 roku.

BIBLIOGRAFIA

ŹRÓDŁA ARCHIWALNE

Archiwum Główne Akt Dawnych w Warszawie rkps Akta Stałej Komisji Śledczej, t. 1, poz. 4098.

fasc. Dieło po monastyrskoj reformie, cz. 1, VII-VIII, 1864, w zespole: Zarząd Generałpolicmajstra, nr 14.

fasc. Dieło po monastyrskoj reformie, cz. 2, w zespole: Zarząd Generał-policmajstra, nr 15. 
Archiwum Prowincji O.O. Bernardynów w Krakowie rkps W-67, Archivum conventus Varthensis sub titulo Beatissimae Virginis Mariae Assumptae in archidioecesi Gnesnensi in palatinatu et districtu Sieradiensi, 1457-1870.

rkps RGP-k-25, Teki Czesława Bogdalskiego, t. 25. rkps RGP-k-62, Teki Czesława Bogdalskiego, t. 45.

sygn. RGP-k-111, Kajetan Jan Grudziński OFM, Bernardyni w stużbie Ojczyzny, 1453-1953. rkps I-1-12, Wykaz alfabetyczny Biskupów i Kapłanów oraz Zakonników polskich przebywających do obecnej chwili na wygnaniu w Syberii i głębokiej Rosji, 1881. rkps XIII-10a, Kronika klasztoru O.O. Bernardynów w Skępem, 1933-1978.

\section{ŹRÓDŁA DRUKOWANE}

Barącz, Sadok. Pamiętnik Zakonu WW. oo. Bernardynów w Polsce. Lwów, 1874.

Berg, Mikołaj Wasiljewicz. Pamiętniki o polskich spiskach i powstaniach. Kraków, 1880.

Giller, Agaton. Polska $w$ walce. T. 1. Paryż, 1868.

Hercen, Aleksander. „Mater Dolorosa”. Kołokot, 97 (1.05.1861).

Prasa tajna z lat 1861-1864. Cz. 1. Red. Stefan Kieniewicz, I. Miller. Warszawa-WrocławKraków, 1966.

Schultz, Serafin. Pamiętnik kapelana. W: Polska w walce. Zbiór wspomnień i pamiętników, 67-143. Paryż, 1868.

\section{OPRACOWANIA}

Bender, Ryszard. „Fijałkowski Antoni Melchior abp.” W: Encyklopedia katolicka. T. 5. Red. Piotr Hemperek, 180. Lublin, 1989.

Chadam, Augustyn. „Konwenty bernardynek. Lublin”. W: Klasztory bernardyńskie w Polsce w jej granicach historycznych. Red. Hieronim Eugeniusz Wyczawski, 524-526. Kalwaria Zebrzydowska, 1985.

Chadam, Augustyn. „Lublin”. W: Klasztory bernardyńskie w Polsce w jej granicach historycznych. Red. Hieronim Eugeniusz Wyczawski, 188-192. Kalwaria Zebrzydowska, 1985.

Chadam, Augustyn. „Łuków”. W: Klasztory bernardyńskie w Polsce w jej granicach historycznych. Red. Hieronim Eugeniusz Wyczawski, 213-215. Kalwaria Zebrzydowska, 1985.

Chadam, Augustyn. „Radecznica”. W: Klasztory bernardyńskie $w$ Polsce $w$ jej granicach historycznych. Red. Hieronim Eugeniusz Wyczawski, 284-293. Kalwaria Zebrzydowska, 1985.

Chadam, Augustyn. „Sokal”. W: Klasztory bernardyńskie w Polsce w jej granicach historycznych. Red. Hieronim Eugeniusz Wyczawski, 342-352. Kalwaria Zebrzydowska 1985.

Choińska, Małgorzata. „Tykocin w czasie powstania styczniowego”. Studia Podlaskie (2006), 16: 9-40.

Chrzanowski, Stefan Marek. Kościót i klasztor pobernardyński pod wezwaniem św. Antoniego $z$ Padwy w Ratowie (1686-1868). Ratowo-Żuromin, 2014.

Chrzanowski, Stefan Marek. „Manifestacje patriotyczne i powstanie styczniowe w cieniu ratowskiego klasztoru bernardynów”. Przegląd Kalwaryjski (2012-2013), 16-17: 27-33.

Dąbrowska, Dorota. „OO. Bernardyni w Łęczycy”. Posłaniec Bernardyński (2000), 2: 10.

Gach, Piotr Paweł. „Formy działalności Braci Mniejszych franciszkanów (bernardynów) na ziemiach dawnej Rzeczypospolitej w latach 1773-1914”. W: Pięćset pięćdziesiąt lat obecności 
oo. Bernardynów w Polsce (1453-2003). Red. Wiesław Franciszek Murawiec, Damian A. Muskus. 265-336. Kalwaria Zebrzydowska, 2006.

Gach, Piotr Paweł. Kasaty zakonów na ziemiach dawnej Rzeczypospolitej i Ślaska 1773-1914. Lublin, 1984.

Gach, Piotr Paweł. Struktury i działalność duszpasterska zakonów męskich na ziemiach dawnej Rzeczypospolitej i Śląska w latach 1773-1914. Lublin, 1999.

Gach, Piotr Paweł. Zakony franciszkańskie na ziemiach dawnej Rzeczypospolitej i Ślaska w latach 1773-1914. W: Zakony franciszkańskie w Polsce. T. 3. Franciszkanie w Polsce XIX wieku. Red. Jerzy Kłoczowski, 11-56. Niepokalanów 1996.

Golichowski, Norbert. Przed nowa epoką. Materiaty do historii oo. Bernardynów w Polsce. Kraków, 1899.

Gołdyn, Piotr. Franciszkanie w powstaniu styczniowym na ziemi konińskiej. Konin, 2002.

Gołdyn, Piotr. „Klasztor w Kole w okresie powstania styczniowego i po jego upadku”. W: Bernardyni w Kole. Wyd. Muzeum Technik Ceramicznych w Kole, 10-20. Koło, 2006.

Grudziński, Kajetan Jan, Aleksander Krzysztof Sitnik. Bernardyni w stużbie Ojczyzny, 1453-1953. Kalwaria Zebrzydowska, 2015.

Grudziński, Kajetan. „Cytowiany”. W: Klasztory bernardyńskie w Polsce $w$ jej granicach historycznych. Red. Hieronim Eugeniusz Wyczawski, 42-44. Kalwaria Zebrzydowska, 1985.

Grudziński, Kajetan. „Datnów”. W: Klasztory bernardyńskie w Polsce w jej granicach historycznych. Red. Hieronim Eugeniusz Wyczawski, 44-47. Kalwaria Zebrzydowska, 1985.

Grudziński, Kajetan. „Działalność patriotyczna”. W: Zakon Braci Mniejszych-franciszkanów. Cz. 3. Zakony św. Franciszka w Polsce w latach 1772-1970. Red. Joachim Roman Bar, 95-131. Warszawa, 1978.

Grudziński, Kajetan. „Józefów”. W: Klasztory bernardyńskie $w$ Polsce $w$ jej granicach historycznych. Red. Hieronim Eugeniusz Wyczawski, 99-102. Kalwaria Zebrzydowska, 1985.

Grudziński, Kajetan. „Koło”. W: Klasztory bernardyńskie w Polsce w jej granicach historycznych. Red. Hieronim Eugeniusz Wyczawski, 140-146. Kalwaria Zebrzydowska, 1985.

Grudziński, Kajetan. „Opatów”. W: Klasztory bernardyńskie $w$ Polsce $w$ jej granicach historycznych. Red. Hieronim Eugeniusz Wyczawski, 239-244. Kalwaria Zebrzydowska, 1985.

Grudziński, Kajetan. „Piotrków Trybunalski”. W: Klasztory bernardyńskie w Polsce w jej granicach historycznych. Red. Hieronim Eugeniusz Wyczawski, 258-264. Kalwaria Zebrzydowska, 1985.

Grudziński, Kajetan. „Radom”. W: Klasztory bernardyńskie $w$ Polsce $w$ jej granicach historycznych. Red. Hieronim Eugeniusz Wyczawski, 293-301. Kalwaria Zebrzydowska, 1985.

Grudziński, Kajetan. „Słonim”. W: Klasztory bernardyńskie $w$ Polsce $w$ jej granicach historycznych. Red. Hieronim Eugeniusz Wyczawski, 334-337. Kalwaria Zebrzydowska, 1985.

Grudziński, Kajetan. „Święta Anna (Przyrów)”. W: Klasztory bernardyńskie w Polsce w jej granicach historycznych. Red. Hieronim Eugeniusz Wyczawski, 365-370. Kalwaria Zebrzydowska, 1985.

Grudziński, Kajetan. „Warszawa - Czerniaków”. W: Klasztory bernardyńskie w Polsce w jej granicach historycznych. Red. Hieronim Eugeniusz Wyczawski, 409-415. Kalwaria Zebrzydowska, 1985.

Grudziński, Kajetan. „Warta”. W: Klasztory bernardyńskie w Polsce w jej granicach historycznych. Red. Hieronim Eugeniusz Wyczawski, 418-426. Kalwaria Zebrzydowska, 1985.

Grudziński, Kajetan. „Wilno”. W: Klasztory bernardyńskie w Polsce w jej granicach historycznych. Red. Hieronim Eugeniusz Wyczawski, 433-440. Kalwaria Zebrzydowska, 1985. 
Grzybowski, Michał Marian. Duchowieństwo katolickie diecezji płockiej w okresie powstania styczniowego. Rocznik Towarzystwa Naukowego Płockiego (2013), 5: 25-42.

Gustaw, Romuald Michał, Aleksander Krzysztof Sitnik. Klasztor i kościót św. Józefa ss. Bernardynek $w$ Krakowie, 1646-2009. Kalwaria Zebrzydowska, 2013.

Gustaw, Romuald. Klasztor i kościót św. Józefa ss. bernardynek w Krakowie, 1646-1946. Kraków, 1947.

Jabłońska-Deptuła, Ewa, Janina, Gawrysiakowa. „Materiały do zaangażowania patriotycznego zakonów męskich w Królestwie Polskim w latach 1861-1864”. W: Materiaty do historii zgromadzeń zakonnych na ziemiach polskich w XIX i początku XX wieku, 391-415. Lublin, 1976.

Kalinowska, Barbara. Bernardyni w Ostrołęce, 1664-1864. Ostrołęka, 2011.

Kalinowska, Barbara. „Kasata zakonów w Królestwie Polskim jako konsekwencja ich zaangażowania w powstanie styczniowe". Zeszyty Naukowe Ostrolęckiego Towarzystwa Naukowego (2003), 17: 36-42.

Kantak, Kamil. Bernardyni polscy, 1573-1795-1932. T. 2. Lwów, 1933.

Kieniewicz, Stefan. Powstanie styczniowe. Warszawa, 1972.

Kieniewicz, Stefan. Warszawa w powstaniu styczniowym. Warszawa, 1954.

Krawczyk, Michał, Wojciech Stan. Bernardyni radomscy. Zarys dziejów. Radom, 2013.

Kubicki, Paweł. Bojownicy kapłani za sprawę Kościoła i Ojczyzny w latach 1861-1915. Cz. 3. T. 3. Sandomierz, 1939.

Kubicki, Paweł. Społeczna działalność Kościoła w Polsce i martyrologium rzymsko-katolickiego duchowieństwa oraz wiernych pod zaborem pruskim i rosyjskim. Sandomierz, 1930.

Kukulski, Jerzy. „Historia klasztoru i kościoła oo. Bernardynów w Piotrkowie Trybunalskim”. W: Królowa ziemi piotrkowskiej. Red. Dawid Czesław Postawa. 37-52. Kraków, 2011.

Lissowski, Czesław. Powstanie styczniowe w ziemi dobrzyńskiej. Płock, 1938.

Murawiec, Wiesław Franciszek. „Bernardyni warszawscy w powstaniu styczniowym 1863 roku”. W: Historia vita memoriae. Prace dedykowane Księdzu Profesorowi Stanisławowi Ludwikowi Piechowi. Red. Jan Bednarczyk. 189-196. Kraków, 2009.

Murawiec, Wiesław Franciszek. Bernardyni warszawscy. Dzieje klasztoru św. Anny w Warszawie 1454-1864. Kraków, 1973.

Murawiec, Wiesław Franciszek. „Mańkowski (Mańko) Benwenuty Walenty (1816-1863), bernardyn”. W: Stownik polskich pisarzy franciszkańskich. Red. Hieronim Eugeniusz Wyczawski, 306-307. Warszawa, 1981.

Murawiec, Wiesław Franciszek. „Zaangażowanie patriotyczne zakonników franciszkańskich Prowincji Niepokalanego Poczęcia NMP w Polsce”. W: Kościót w Polsce. Dzieje i kultura. T. 9. Red. Jan Walkusz, 297-319. Lublin, 2010.

Murawiec, Wiesław. „Budsław”. W: Klasztory bernardyńskie w Polsce $w$ jej granicach historycznych. Red. Hieronim Eugeniusz Wyczawski, 31-34. Kalwaria Zebrzydowska, 1985.

Murawiec, Wiesław. „Góra Kalwaria”. W: Klasztory bernardyńskie w Polsce $w$ jej granicach historycznych. Red. Hieronim Eugeniusz Wyczawski, 70-74. Kalwaria Zebrzydowska, 1985.

Murawiec, Wiesław. „Kalisz”. W: Klasztory bernardyńskie w Polsce w jej granicach historycznych. Red. Hieronim Eugeniusz Wyczawski, 107-113. Kalwaria Zebrzydowska, 1985.

Murawiec, Wiesław. „Kielce”. W: Klasztory bernardyńskie w Polsce w jej granicach historycznych. Red. Hieronim Eugeniusz Wyczawski, 133-135. Kalwaria Zebrzydowska, 1985. 
Murawiec, Wiesław. „Mańkowski (Mańko) Walenty, imię zakonne Benwenuty”. W: Polski stownik biograficzny. T. 19. Red. Emanuel Rostworowski, 514. Wrocław-Warszawa-Kraków-Gdańsk, 1974.

Murawiec, Wiesław. „Mohylew”. W: Klasztory bernardyńskie $w$ Polsce $w$ jej granicach historycznych. Red. Hieronim Eugeniusz Wyczawski, 223-226. Kalwaria Zebrzydowska, 1985.

Murawiec, Wiesław. „Nieśwież”. W: Klasztory bernardyńskie $w$ Polsce $w$ jej granicach historycznych. Red. Hieronim Eugeniusz Wyczawski, 228-233. Kalwaria Zebrzydowska, 1985.

Murawiec, Wiesław. „Skępe”. W: Klasztory bernardyńskie w Polsce w jej granicach historycznych. Red. Hieronim Eugeniusz Wyczawski, 322-334. Kalwaria Zebrzydowska, 1985.

Murawiec, Wiesław. „Warszawa - św. Anna”. W: Klasztory bernardyńskie w Polsce w jej granicach historycznych. Red. Hieronim Eugeniusz Wyczawski, 398-409. Kalwaria Zebrzydowska, 1985.

Nowakowski, Edward. „Spis duchowieństwa przebywającego w Tunce na Syberii”. W: W czterdziestą rocznicę powstania styczniowego. Lwów, 1903.

Orzechowska, Elżbieta. „Bernardyni radomscy w życiu narodu polskiego w XIX wieku”. W: Wpisani w dzieje Radomia. Pięćset pięćdziesiąa rocznica przybycia oo. Bernardynów do Radomia (1468-2018). Red. Michał Krawczyk, Aleksander Krzysztof Sitnik, 133-182. Kalwaria Zebrzydowska, 2018.

Orzechowska, Elżbieta. Radomscy bernardyni w dobie powstania styczniowego. Radom, 2008.

Orzechowska, Elżbieta. „Z działalności patriotycznej bernardynów w Radomiu w dobie powstania styczniowego". W: Zakony franciszkańskie w Polsce. T. 3. Franciszkanie w Polsce w XIX wieku, 149-161. Niepokalanów, 1996.

Pabin, Andrzej. „Paradyż”. W: Klasztory bernardyńskie w Polsce w jej granicach historycznych. Red. Hieronim Eugeniusz Wyczawski, 251-254. Kalwaria Zebrzydowska, 1985.

Pietrzak, Józef Stanisław. Księża powstańcy 1863. Kraków, 1916.

[Płonka, Wacław]. Kościół i klasztor oo. Bernardynów w Łęczycy. Nakładem Komitetu Odnowienia Kościoła i Klasztoru. [Łęczyca], 1947.

Prejs, Roland. „Bernardyni prowincji małopolskiej po kasacie 1864 r.” Studia Franciszkańskie (1999), 10: 327-371.

Prejs, Roland. „Bernardyni w Królestwie Polskim po kasacie 1864 r.” W: Pięćset pięćdziesiąt lat obecności oo. Bernardynów w Polsce (1453-2003). Red. Wiesław Franciszek Murawiec, Damian Muskus, 427-514. Kalwaria Zebrzydowska, 2006.

Prejs, Roland. „Klasztor bernardynów w Paradyżu (Wielkiej Woli) w latach 1864-1893. Przykład funkcjonowania klasztoru etatowego w Królestwie Polskim w warunkach pokasacyjnych". Studia Franciszkańskie (2001), 11: 275-306.

Prejs, Roland. „Klasztor bernardynów w Radecznicy w latach 1864-1919”. W: Na tym miejscu chwała Boga Najwyższego odprawiać się będzie... W setna rocznicę rewindykacji klasztoru oo. Bernardynów w Radecznicy (1919-2019). Red. Iwo Mirosław Janusz, Aleksander Krzysztof Sitnik, 117-132. Kalwaria Zebrzydowska, 2019.

Prejs, Roland. Zakonnicy franciszkańscy Królestwa Polskiego po kasacie 1864 roku. Dzieje postawy. Warszawa, 2003.

Przygodzki, Sławomir. „Losy bernardynów kaliskich i klasztoru w okresie zaborów (1793-1914)”. W: 400 lat konsekracji pobernardyńskiego kościoła jezuitów w Kaliszu. Materiały z sesji popularnonaukowej poświęconej historii światyni i przylegającego do niej klasztoru. Red. Jerzy Kacprzyk, Aleksander Jacyniak, 58-84. Kalisz, 2007. 
Raciborski Józef. „Kościół i klasztor oo. Bernardynów”. Kronika Dyecezyi Kujawsko-Kaliskiej (1924), 10: 435.

Rawicz-Witanowski, Michał. Monografia Łęczycy. Kraków, 1898.

Rosin Ryszard, Stefan Pytlas, Krzysztof Woźniak. „Lata zaborów”. W: Lęczyca. Monografia miasta do 1990 roku. Red. Ryszard Rosin, 225-350. Łęczyca, 2001.

Sitnik, Aleksander Krzysztof. „Akta klasztoru i kościoła oo. Bernardynów w Piotrkowie Trybunalskim w zasobie Archiwum Prowincji oo. Bernardynów w Krakowie”. W: Królowa ziemi piotrkowskiej. Red. Dawid Czesław Postawa. 121-151. Kraków, 2011.

Sitnik, Aleksander Krzysztof. „Archiwista i muzealnik Kajetan Grudziński OFM (1916-1986)”. W: Niezwykli franciszkanie XX/XXI stulecia. Cz. 2. Red. Salezy Bogumił Tomczak, 119-130. Poznań, 2012.

Sitnik, Aleksander Krzysztof. „Księgozbiór klasztoru oo. Bernardynów w Kole nad Wartą (II połowa XV - I połowa XX wieku)”. W: Królewskie miasto Koło. Studia w 650. rocznicę lokacji miasta. Red. Izabela Skierska, 215-234. Koło, 2012.

Sitnik, Aleksander Krzysztof. „Różnorodne formy kultu Matki Bożej Skępskiej”. W: Rozwój kultu Matki Bożej inspirowany przez figurę Najświętszej Maryi Panny Skępskiej Królowej Mazowsza, Kujaw i Ziemi Dobrzyńskiej. Red. Aleksander Krzysztof Sitnik, 7-22. Kalwaria Zebrzydowska, 2018.

Sitnik, Aleksander Krzysztof, Tomasz Sitnik. Bernardyni łęczyccy. Dzieje klasztoru i kościoła pw. Niepokalanego Poczęcia NMP oo. Bernardynów w Lęczycy (1632-1864, od 1946), Kalwaria Zebrzydowska, 2006.

Sitnik, Aleksander Krzysztof. „Udział bernardynów kolskich w powstaniu styczniowym i ich późniejsze losy". W: Powstanie styczniowe na ziemi kolskiej - w 150. rocznicę zrywu narodowego. Red. Krzysztof Witkowski, 81-96. Koło, 2013.

Sitnik, Aleksander Krzysztof. „Udział Bernardynów w powstaniu listopadowym i popowstaniowe losy ich klasztorów”. Roczniki Teologiczne 67 (2020), 4: 61-80.

Sitnik, Aleksander Krzysztof. „W 390 rocznicę fundacji kościoła pw. św. Karola Boromeusza na Karczówce w Kielcach (1624-2014)”. Przeglad Kalwaryjski (2014), 18: 125-138.

Skarbek, Jan. „Sowińska ze Schroederów Katarzyna Antonina”. W: Polski słownik biograficzny (2000-2001), 40: 632.

Wyczawski, Hieronim Eugeniusz. Arcybiskup Zygmunt Szczęsny Feliński, 1822-1895. Warszawa, 1975.

Wyczawski, Hieronim Eugeniusz. Bernardyni polscy, 1772-1946. T. 3. Kalwaria Zebrzydowska, 1992.

Wyczawski, Hieronim Eugeniusz. „Katalog Archiwum Prowincji oo. Bernardynów w Krakowie”. Archiwa, Biblioteki i Muzea Kościelne (1962), 4: 23-225.

Wyczawski, Hieronim Eugeniusz. „Kazimierz Biskupi”. W: Klasztory bernardyńskie w Polsce w jej granicach historycznych. Red. Hieronim Eugeniusz Wyczawski, 126-133. Kalwaria Zebrzydowska, 1985.

Wyczawski, Hieronim Eugeniusz. „Kobyłka”. W: Klasztory bernardyńskie w Polsce w jej granicach historycznych. Red. Hieronim Eugeniusz Wyczawski, 140. Kalwaria Zebrzydowska, 1985.

Wyczawski, Hieronim Eugeniusz. „Łęczyca”. W: Klasztory bernardyńskie w Polsce w jej granicach historycznych. Red. Hieronim Eugeniusz Wyczawski, 197-200. Kalwaria Zebrzydowska, 1985. 
Wyczawski, Hieronim Eugeniusz. „Przasnysz”. W: Klasztory bernardyńskie w Polsce w jej granicach historycznych. Red. Hieronim Eugeniusz Wyczawski, 274-278. Kalwaria Zebrzydowska, 1985.

Wyczawski, Hieronim Eugeniusz. „Ratowo”. W: Klasztory bernardyńskie w Polsce w jej granicach historycznych. Red. Hieronim Eugeniusz Wyczawski, 301-303. Kalwaria Zebrzydowska, 1985.

Wyczawski, Hieronim Eugeniusz. „Schultz (Szulc) Serafin (ok. 1831-1905), bernardyn”. W: Stownik polskich pisarzy franciszkańskich. Red. Hieronim Eugeniusz Wyczawski, 433-434. Warszawa, 1981.

Wyczawski, Hieronim Eugeniusz. „Strzegocin”. W: Klasztory bernardyńskie w Polsce w jej granicach historycznych. Red. Hieronim Eugeniusz Wyczawski, 357-360. Kalwaria Zebrzydowska, 1985.

Wyczawski, Hieronim Eugeniusz. „Widawa”. W: Klasztory bernardyńskie w Polsce w jej granicach historycznych. Red. Hieronim Eugeniusz Wyczawski, 426-430. Kalwaria Zebrzydowska, 1985.

Zdanowski, Józef. Karczówka pod Kielcami. Kielce, 1928.

Zieliński, Zygmunt. Papiestwo i papieże dwóch ostatnich wieków. Warszawa, 1999.

Żmichowska, Narcyza. Listy. T. 2. Wrocław, 1960.

\section{UDZIAŁ BERNARDYNÓW W POWSTANIU STYCZNIOWYM I ICH PÓŹNIEJSZE LOSY}

$$
\text { Streszczenie }
$$

Według historyków udział Zakonu Braci Mniejszych (bernardynów) w powstaniu styczniowym był znaczący. W świetle źródeł historycznych zapisali oni piękną kartę w zrywie narodowym. Uznać to trzeba za zryw szlachetny, jak stwierdził bernardyński historyk Hieronim Eugeniusz Wyczawski, będący wyrazem umiłowania Ojczyzny i wolności. $Z$ drugiej jednak strony nie sposób nie dostrzec, że w podejmowanych przez bernardynów akcjach było dużo nierozwagi, brak umiejętności organizowania pracy konspiracyjnej i niemało łatwowierności. W niniejszym opracowaniu przedstawiłem działalność bernardynów w Królestwie Kongresowym i na ziemiach bezpośrednio wcielonych do rosyjskiego imperium, gdzie był duży ucisk narodowościowy i gdzie wybuchło krwawe powstanie styczniowe 22 stycznia 1863 r. w Królestwie Polskim i 1 lutego 1863 r. w byłym Wielkim Księstwie Litewskim. W omawianym okresie wystąpiły wielorakie ograniczenia życia zakonnego, również dla prowincji bernardyńskich. Władze zaborcze nie tylko deklarowały niechęć wobec tej formy życia, ale stopniowo ograniczały i likwidowały struktury zakonne, pojedyncze klasztory i całe prowincje. Kasatom klasztorów towarzyszyły grabieże ich mienia, zabór archiwów i bibliotek, wykorzystywanie pomieszczeń kościelnych i klasztornych na cele świeckie. Kasata rozbiła struktury bernardynów w Królestwie Polskim. W wielu zakonnikach zagubiła sens prowadzenia życia zakonnego, co przejawiało się w częstych prośbach o sekularyzację oraz w emigracji. Była to cena, jaką bernardyni płacili za zaangażowanie patriotyczne i związanie swego życia z losami społeczeństwa polskiego.

Słowa kluczowe: bernardyni; klasztor; kasata. 